\title{
Corrosion Behavior of Sodium-Exposed Stainless Steels in Chloride-Containing Aqueous Solutions
}

\author{
Paul C. S. Wu
}

\begin{abstract}
Any futher distribution by any holder of this document or of the data therein to thrra panteresenting foreign governments, foreign companierand ansidiaries or foreign divisions of U.S. comperes should be coordinated Division of Rear Research and Development, Department of Energy.
\end{abstract}

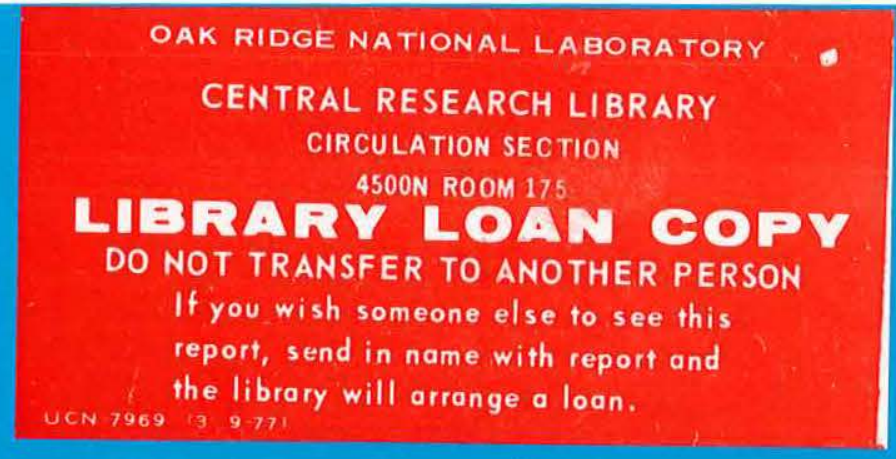

\section{OAK RIDGE NATIONAL LABORATORY}

OPERATED BY UNION CARBIDE CORPORATION · FOR THE DEPARTMENT OF ENERGY 


\section{Printed in the United States of America. Available from the Department of Energy, Technical Information Center \\ P.O. Box 62, Oak Ridge, Tennessee 37830 \\ Price: Printed Copy $\$ 6.00$; Microfiche $\$ 3.00$}

This report was prepared as an account of work sponsored by an agency of the United States Government. Neither the United States Government nor any agency thereof, nor any of their employees, contractors, subcontractors, or their employees, makes any warranty, express or implied, nor assumes any legal liability or responsibility for any third party's use or the results of such use of any information, apparatus, product or process disclosed in this report, nor represents that its use by such third party would not infringe privately owned rights. 
34456 0509846?

ORNL/TM-6068

Dist. Category UC-79C

Contract No. W-7405-eng-26

ADVANCED FUEL RECYCLE PROGRAM

CORROSION BEHAVIOR OF SODIUM-EXPOSED

STAINLESS STEELS IN CHLORIDE-CONTAINING

AQUEOUS SOLUTIONS

Paul C. S. Wu

Westinghouse Electric Corporation

Advanced Reactors Division

Date Published: December 1977

NOTICE This document contains information of a preliminary nature. It is subject to revision or correction and therefore does not represent a final report.

Prepared under Subcontract 7168

OAK RIDGE NATIONAL LABORATORY

Oak Ridge, Tennessee 37830

operated by

UNION CARBIDE CORPORATION

for the

DEPARTMENT OF ENERGY 

CONTRIBUTORS

B. R. Grundy

N. L. Haines

S. A. Meacham

R. L. Miller

S. J. Orbon

C. R. Simmons

P. C. S. Wu 


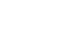

(

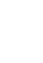




\section{TABLE OF CONTENTS}

SECTION

PAGE

$\begin{array}{ll}\text { SUMMARY } & 1\end{array}$

1.0 INTRODUCTION 2

2.0 WORK SCOPE AND TEST MATRIX 3

3.0 SODIUM RECONDITIONING 8

3.1 Materials and Specimens 8

3.1.1 Corroded Type 316 Stainless Stee] 9

3.1.2 Deposit-Bearing Type 304 Stainless Stee1 10

$\begin{array}{lll}3.2 & \text { Results on Sodium Reconditioning } & 11\end{array}$

4.0 SODIUM REMOVAL 26

4.1 Alcohol Process . 26

$\begin{array}{ll}4.2 \text { Water Vapor/Argon Process } & 27\end{array}$

4.3 Steam/Argon Process 27

4.4 Summary 28

5.0 WATER EXPOSURE $\quad 47$

5.1 Test Conditions 47

5.2 Test Procedure and Operation 48

5.3 Test Results 49

5.3.1 Corroded Type 316 Stainless Steel Specimens 50

5.3.2 Deposit-Bearing Type 304 Stainless Steel 50 Specimens

5.3.3 Additional Testing 51

6.0 POST-TEST SPECIMEN CHARACTERIZATION 57

6.1 Corroded Type 316 Stainless Steel 57

6.2 Deposit-Bearing Type 304 Stainless Stee1 59 


\section{TABLE OF CONTENTS (Contd.)}

SECTION

PAGE

7.0 CONCLUSION

7.1 Corroded Type 316 Stainless Steel

75

7.2 Deposit-Bearing Type 304 Stainless Steel

75

7.3 Recommendations

8.0 REFERENCES

78 


\section{LIST OF FIGURES}

FIGURE

PAGE

3-1 Photograph of the Corrosion Capsules 17

3-2 Surface Appearance of the Type 304 SS Specimens Before 18 Sodium Exposure

3-3 Schematic Drawing of an MTL System 19

3:4 Microstructure of Corroded 20\% Cold-Worked Type 316SS 20

(5300 Hrs. in $2.1 \mathrm{~m} / \mathrm{s}$ Sodium at $649^{\circ} \mathrm{C}$ )

3-5 Microstructure of Corroded 20\% Cold-Worked Type 316 SS 21

(5300 Hrs. in $2.1 \mathrm{~m} / \mathrm{s}$ Sodium at $718^{\circ} \mathrm{C}$ )

3-6 MTL-1-10 Economizer Tube Temperature Distribution 22

3-7 Microstructure of Deposit-Bearing Type 304 SS 23

3-8 Typical Surface Condition of the Type 316 SS Specimen. 24 After Sodium Exposure

3-9 Typical Surface Condition of the Type 304 SS Specimens 25 After Sodium Exposure

4-1 Typical Surface Condition of the Type 316 SS Specimens 36 After Sodium Removal By the Alcohol Process

4-2 Typeical Surface Condition of the Type 304 SS Specimens 37 After Sodium Removal By the Alcohol Process

4-3 Schematic of WVA for Cladding Speicmens from MTL-4 Runs 1 and 338

4-4 Effluent Hydrogen During WVA Process For Cladding Specimens 39 from Sections 1 and 3, MTL-4 Runs 1 and 3

4-5 Typical Surface Condition of the Type 316 SS Specimens After 40 Sodium Removal By the Water Vapor/Argon Process

4-6 Typical Surface Condition of the Type 304 SS Specimens After 41 Sodium Removal By the Water Vapor/Argon Process

4-7 Schematic of Steam/Argon Process for Cladding Section 2, 42 MTL-4 Run 2

4-8 Effluent Hydrogen During Steam/Argon Process for Type 316 SS 43 Cladding Specimens

4-9 Comparison of Sodium Removal Expediency 44

4-10 Typical Surface Condition of the Type 316 SS Specimens After 45 Sodium Removal BY the Steam/Argon Process

5-1 Schematic Diagram of Water Exposure Sys tem 56

6-1 Electron Microprobe Analyses of the Sodium Corroded (5300 Hrs. 62 at $718^{\circ} \mathrm{C}$ ) $20 \%$ Cold-Worked Type 316 SS。

$6-2$ SEM Photomicrograph of Sodium-Exposed (5300 Hrs. at $718^{\circ} \mathrm{C}$ ) $20 \%$ Cold-Worked Type 376 SS 


\section{LIST OF FIGURES (Cont.)}

FIGURE

PAGE

6-3 Surface Morphology and Element Distribution of Sodium-Exposed (5300 Hrs, at $649^{\circ} \mathrm{C}$ ) $20 \%$ Cold-Worked Type 316 SS

6-4 Steam/Argon Cleaned Deposit-Bearing Type 304 SS Specimens 65

6-5 Surface Appearance of Post-Water Exposed Deposit-Bearing 66 Type 304 SS

6-6 Microstructure of Deposit-Bearing Type 304 SS After Neutral 67 and High Chloride Water Exposure $\left(82^{\circ} \mathrm{C}, 10\right.$ days)

6-7 Photomicrograph of Post-Water Exposed Deposit-Bearing 68 Type 304 SS

6-8 SEM Photomicrograph of Sodium-Exposed Stainless Steels 69

6-9 SEM Photomicrograph of Deposit Bearing Sodium-Exposed 70 Type 304 SS

6-10 EDAX Analysis of Deposit-Bearing Na-Exp., And Steam/Argon 71 Cleaned Type 304 SS

6-11 SEM and EDAX Analysis of Deposit-Bearing Type 304 SS After 72 Water Exposure

6-12 EDAX Analysis of the Reaction Products Shown in Figure 6-11 73

6-13 SEM Photomicrographs of Sodium-Exposed Type 304 SS After 74 High Chloride and Neutrol Water Exposure 


\section{LIST OF TABLES}

TABLE

PAGE

2-1 Test Matrix of Sodium Removal and Water Exposure of SodiumExposed Stainless Steels

2-2 Chemistry of Water Bath for Cladding Material Water Exposure

3-1 Chemical Composition and Mechanical Properties of $20 \%$ ColdWorked Type 316 SS Tubing

3-2 Chemical Composition and Mechanical Properties of Annealed Type 304 SS

3-3 Sodium Exposure History of Corroded Type 316 Stainless Stee1 15

3-4 Sodium Recondition History of the Test Material 16

4-1 Dowanol EB Process Control and End-of-Step Requirements 29

4-2 Results on Sodium Removal by the Alcohol Process 30

4-3 WVA Process Control and End-of-Step Requirements 31

4-4 Results on Sodium Removal by the WVA Process 32

4-5 Steam/Argon Process Control and End-of Step Requirements 33

4-6 Results for Steam/Argon Process on 20\% Cold-Worked Type $316 \quad 34$ SS Specimens No. 2-7

4-7 Sodium Cleaning History of Cladding Specimens 35

5-1 Corroded Type 316 SS Specimens Exposed in Water Baths 52

5-2 Status of Water Exposure - Corroded Type 316 SS 53

5-3 Deposit-Bearing Type 304 SS Specimens Exposed in Vater Baths 54

5-4 Status of Water Exposure - Deposit-Bearing Type 304 SS 55 

,

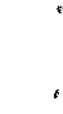

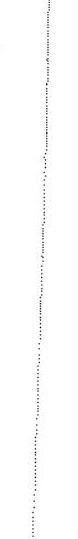

.

( . 


\section{SUMMARY}

Corrosion behavior of sodium-exposed stainless steels in typical water pool conditions was investigated. The main purpose of this study was to assess the feasibility of water storage concepts for the LMFBR spent fuels. This report covers phase 1 of this program which was a screening study of sodium-corroded, 20\% cold-worked Type 316 stainless steel (prototypic LMFBR cladding alloy) with the sodium removed by alcohol or water vapor/argon and/or steam/argon process. The results show that no observable material deterioration or failure occurred among specimens manufactured from this material and tested under pressurized condition (350 psi) at $82^{\circ} \mathrm{C}$ for periods up to five months in various water baths with chloride content above $500 \mathrm{ppm}$. This satisfactory performance was mainly due to two factors: 1) massive intragranular carbide precipitation due to the cold-working which prevented the alloy from sensitizing during high temperature sodium exposure, which in turn reduced the susceptibility of the alloy to intergranular attack, and 2) the presence of a ferrite layer with high molybdenum which enhanced the alloy's resistance to localized pitting corrosion.

Deposit-bearing Type 304 stainless steel specimens manufactured from an economizer (liquid sodium heat exchanger) were also studied under the same conditions. Rusting developed on most of the specimens in all four water baths; however, failure occurred mainly in the high chloride and neutral water bath. It was concluded that the failures were initiated by severe localized pitting and subsequently accelerated by intergranular attack. These failures were attributed to the presence of mass transfer deposits particularly iron and its compounds and to the sensitized structure of the base alloy. It was also found that high pH tends to enhance the corrosion resistance of this alloy. In addition, the failure was apparently independent of the sodium cleaning procedures employed for the removal of sodium from the test specimens. 


\subsection{INTRODUCTION}

In order to ensure capability of completing the fuel cycle in a sodium cooled fast breeder reactor economy, a comprehensive research and development program is being conducted by ERDA to address and solve the new problems introduced by LMFBR fuels. One of the major efforts involves 1 imiting the fuel storage requirements of early breeders by providing the industry with a sound and economic fuel reprocessing capability.

One immediate concern of the overall LMFBR fuel reprocessing technology is the selection of a safe and satisfactory method to remove the sodium from the fue 7 assemblies and to store before the fuels of this reprocessing site until they can be recovered. A sodium pool would be functionally acceptable for storing the LMFBR spent fuels. However, economic considerations dictate the need for evaluating the feasibility of water pit storage for the LMFBR spent fueTs.

An extensive literature survey was conducted by English ${ }^{(1)}$ who examined the feasibility of safe, long-term storage of irradiated spent-fuel subassemblies from high-temperature, sodium cooled, liquid metal fast breeder reactors (LMFBRs); particularly the Fast Flux Test Facility (FFTF) and the Clinch River Breeder Reactor (CRBR), prior to the reprocessing of the fuel elements. Based on this survey, it appears that the use of water pools has been widely accepted for the storage of irradiated metal-clad fuels (those that are not sodium bonded) as a safe practice because it is adequate, economical, and convenient. Consequently, the appeal of water storage of spent fuel elements for the proposed LMFBR Fuel Reprocessing Hot Pilot Plant (HPP) is considerable.

The corrosion behavior of sodium-exposed stainless steels in aqueous solutions has not been fully characterized, and the effect of water on the integrity of fuel element cladding may be significant. The main purpose of the present investigation is to experimentally determine the corrosion behavior of sodium-exposed stainless steels, after various sodium removal procedures, and in various aqueous solutions that might be used in a fuel storage pool. The preliminary results obtained in the current study provide valuable information needed in assessing the feasibility of water storage for LMFBR spent fuels. 


\subsection{WORK SCOPE AND TEST MATRIX}

The present program consisted of five phases which were conducted concurrent1y:

(1) A literature survey was conducted to evaluate the effect of radiation on the corrosion behavior of stainless steels in water. In addition, subjects such as sensitization, intergrannular attack, and stress corrosion cracking of stainless steels were also reviewed.

(2) Fuel cladding material prototypic of FFTF and CRBRP (20\% cold-worked and sodium exposed at temperatures of 649 and $718^{\circ} \mathrm{C}$ for time periods of approximately 5000 hours), was gathered, identified, and re-exposed to sodium to recondition the surface under the same conditions which they previousiy experienced.

(3) Three previously developed sodium removal procedures were employed on the test samples. The three methods employed were the alcohol process (AI procedure), the water vapor/argon process (HEDL procedure), and the steam/argon process (KNK procedure).

(4) Preliminary water corrosion of the sodium exposed specimens, $20 \%$ coldworked Type 316 stainless steel cladding material which had been reconditioned, identified, and cleaned according to (2) and (3) respectively, was conducted. In addition, specimens of annealed Type 304 SS with surfaces typical of material deposition in the low temperature region of a dynamic sodium system were also tested.

The specimens selected covered basically two types of mass transfer changes resulting from sodium exposure. One group of 
specimens was previously exposed to sodium at temperatures of 649 and $718^{\circ} \mathrm{C}\left(1200\right.$ and $\left.1325^{\circ} \mathrm{F}\right)$ for a period of 5000 hours. This group represented corrosion and selective alloy depletion. Another group of specimens fabricated from Type 304 stainless steel previously sodium-exposed from $440^{\circ} \mathrm{C}$ to $575^{\circ} \mathrm{C}\left(825\right.$ to $1065^{\circ} \mathrm{F}$ ) for up to 3000 hours provided surface conditions which were prototypic of the mass transfer deposition region in a sodium-stainless steel system. Therefore, the specimens selected exhibited various types of mass transfer changes.

The specimens were exposed to water for times up to three months; the water conditions, such as temperature and chemistry were (a) prototypic of LWR water storage pit chemistry and at $82 \pm 5^{\circ} \mathrm{C}\left(180 \pm 10^{\circ} \mathrm{F}\right)$. The high temperature $\left(82^{\circ} \mathrm{C}\right)$ was used, instead of the typical PWB water pit temperature of $27^{\circ} \mathrm{C}\left(80^{\circ} \mathrm{F}\right)$, to simulate local temperature rise caused by decay heat in the fuel pins; (b) an accelerated test with high chloride was also included in the test matrix.

(5) The preliminary data on Type 316 stainless steel were evaluated and recommendations on water storage of spent LMFBR fuel were made as shown in Section 7 .

Additional work required to substantiate the preliminary results or for solving any identified problems was defined in Section 5 . In addition, testing of a complete fuel assembly was defined in Section 4.

The test matrix for sodium removal and water exposure of the test materials is shown in Table 2-1. A total of thirty (30) Type 316 stainless steel cladding specimens were investigated. These specimens were sodium cleaned by the various sodium removal procedures before exposing to the various water baths for periods up to three (3) months. The specimen distribution with respect to the sodium removal method, test 
period, and water bath condition are given in Table 2-1. An identical test matrix and specimen distribution was also designed for the Type 304 stainless steel specimens.

The chemistries of the four (4) water baths are defined in Table 2-2. There are two chloride levels where the chloride content varies from less than $0.15 \mathrm{ppm}$ in baths \#1 and \#2 to above $500 \mathrm{ppm}$ in baths \#3 and \#4. The $0.15 \mathrm{ppm}$ or less chloride level was chosen to simulate that of a typical PWR water storage pool condition while the higher chloride level chosen for the other two baths was the approximate chloride environment reported in the water storage facility at the Idaho Chemical Reprocessing Plant, a level felt to be an extreme. ${ }^{(2)}$ There are two $\mathrm{pH}$ levels for a given chloride content as defined in Table 2-2. Since the presence of residual sodium on the test specimens, due to incomplete sodium removal would lead to a local caustic environment during water exposure, the $\mathrm{pH}$ level of ten (10) was included in addition to the neutral condition of $\mathrm{pH}=7$ in the present investigation. 
Table 2-1

Test Matrix for Sodium Removal and Water Exposure of Sodium-Exposed Stainless Steels ${ }^{(a)}$

\begin{tabular}{|l|c|c|c|c|c|}
\hline \multirow{2}{*}{$\begin{array}{c}\text { Na Removal } \\
\text { Method }\end{array}$} & $\begin{array}{c}\text { Test } \\
\text { Period } \\
\text { (Month) }\end{array}$ & \multicolumn{4}{|c|}{ Water Bath (b) } \\
\cline { 3 - 6 } & 1 & & & & \\
\hline \multirow{3}{*}{ Alcoho1 } & 2 & & & & \\
\cline { 2 - 6 } & 3 & 1 & 1 & 1 & 1 \\
\hline \multirow{3}{*}{$\begin{array}{l}\text { Water Vapor } \\
\text { Argon } \\
\text { (WARD) }\end{array}$} & 1 & & 1 & 1 & 1 \\
\cline { 2 - 6 } & 2 & & 1 & 1 & 1 \\
\hline \multirow{3}{*}{$\begin{array}{l}\text { Steam-Argon } \\
\text { (KNK) }\end{array}$} & 2 & 2 & 2 & 2 & 1 \\
\cline { 2 - 6 } & 3 & 2 & 2 & 2 & 1 \\
\hline
\end{tabular}

(a) $20 \%$ cold-worked Type 316 SS tubing (0.230" $0 . D . \times 0.015^{\prime \prime} \mathrm{W}$ ) sodium exposed at $649-718^{\circ} \mathrm{C}\left(1200-1325^{\circ} \mathrm{F}\right)$ for 5000 hours, and Type 304 SS tubing $\left(0.437^{\prime \prime}\right.$ O.D. $\left.x 0.020^{\prime \prime} \mathrm{W}\right)$ sodium exposed at $440-575^{\circ} \mathrm{C}\left(825-1065^{\circ} \mathrm{F}\right)$ for 23000 hours.

(b) The number of specimens tested in each bath is shown in a given "block". 
Table 2-2

Chemistry of Water Bath for Cladding Material Water Exposure

\begin{tabular}{|c|c|c|c|c|}
\hline \multirow{2}{*}{ Property } & \multicolumn{4}{|c|}{ Water Bath Chemistries } \\
\hline & \#1 & $\frac{\$ 12}{12}$ & $\# 3$ & $\overline{\# 4}$ \\
\hline$\underbrace{\text { Chloride }}_{(\mathrm{ppm})}$ & $\leq 0.15$ & $\leq 0.15$ & $\geq 500$ & $\geq 500$ \\
\hline $\mathrm{pH}$ & $7.0+0.5$ & $70 \pm 7^{(b)}$ & $7.0 \pm 0.5$ & $10 \pm]^{(b)}$ \\
\hline $\begin{array}{l}\text { Dxygen content } \\
(\mu \mathrm{g} / \mathrm{cc})\end{array}$ & 5.3 & 5.3 & 5.3 & 5.3 \\
\hline $\begin{array}{l}\text { Sodium Ion } \\
\text { Content }\end{array}$ & $\begin{array}{c}\text { Not } \\
\text { Controlled } \\
(d)\end{array}$ & $\begin{array}{c}\text { Raised by } \\
\mathrm{NaOH} \text { Addition }\end{array}$ & $\begin{array}{l}\text { Not } \\
\text { Controlled }\end{array}$ & $\begin{array}{c}\text { Raised By } \\
\mathrm{NaOH} \text { Addition }\end{array}$ \\
\hline $\begin{array}{c}\text { Conductivity } \\
\text { (uohms) }\end{array}$ & $\leq 5$ & $\begin{array}{c}\text { Not } \\
\text { Controlled }\end{array}$ & $\stackrel{\text { Not }}{\text { Controlled }}(d)$ & $\begin{array}{c}\text { Not } \\
\text { Controlled (d) }\end{array}$ \\
\hline
\end{tabular}
(a) Adjusted by $\mathrm{NaCl}$
(b) Raised by $\mathrm{NaOH}$ Additions
(c) Saturated at $82^{\circ} \mathrm{C}\left(180^{\circ} \mathrm{F}\right)$
(d) Will be measured 


\subsection{SODIUM RECONDITIONING}

Due to the urgent need for information*, it was decided to make use of the stainless steel tubing, which had been previously sodium exposed, for this investigation.

The immediately available material consisted of eight (8) feet of sodiumexposed, $20 \%$ cold-worked Type 316 stainless steel prototypic cladding alloy and ten (10) feet of sodium-exposed Type 304 stainless steel tubing. These materials had been cleaned by alcohol process and stored in a plastic bag in an inert atmosphere condition for approximately six (6) years. Consequently, it was necessary to recondition the surface by reinserting these materials under conditions which they had previously experienced. This reconditioning not only provided a surface which is prototypic of the mass transfer changes resulting from sodium exposure, it also provided a condition for evaluating the adequacy of the various sodium removal techniques.

\subsection{Materials and Specimens}

Two types of sodium pre-exposed stainless steels were studied in the present investigation. The corroded Type 316 stainless steel tubing (0.230" 0.D. and $0.015^{\prime \prime}$ wal1) was previous ly sodium exposed in a corrosion region while the annealed Type 304 stainless steel tubing $\left(0.437^{\prime \prime}\right.$ O.D. and 0.020 " wa11) was sodium exposed in a deposition area. The chemical composition and mechanical properties of these materials are given in Tables 3-1 and 3-2, respectively. Thirty (30) specimens, in the form of capsules, were manufactured from the above materials. These capsules were approximately 3 inches long designed with a top and bottom end-cap which

* A major milestone in the LMFBR Fuel Recycle Program was the selection of the spent fuel storage coolant media for Hot Pilot Plant by July 1, 1977. 
provided access for pressurization, to simulate internal stresses due to fission gas, during the subsequent water corrosion studies. In addition, an insert was included in the capsule for the purpose of reducing stored energy. The specimen dimensions and their general appearances for the Types 316 and 304 stainless steel specimens are shown in Figures $3-1$ and $3-2$, respectively.

Since the test specimens were made from stainless stee 1 tubings which were sodium-exposed six (6) years ago, it was necessary to recondition the specimen surface by re-exposing them in a sodium system in corrosion or deposition regions typical of their prior history for a period of about two (2) weeks. The schematic diagram of the nonisothermal dynamic sodium system (Loop system MTL-4), used for the reconditioning work, is shown in Figure 3-3.

\subsubsection{Corroded Type 316 Stainless Stee1}

The corroded specimens were made of $20 \%$ cold-worked Type 316 stainless steel cladding material with the different sodium exposure histories which are described in the flow chart shown in Table 3-3. Basically, the two groups of the typical cladding material had been exposed previously in an identical sodium environment except for the sodium temperature. As

shown in Table $3-3$, one group had been sodium pre-exposed at $718^{\circ} \mathrm{C}\left(1325^{\circ} \mathrm{F}\right)$ while the other group had been pre-exposed to $649^{\circ} \mathrm{C}\left(1200^{\circ} \mathrm{F}\right)$ sodium. After the initial sodium exposure, the tubing specimens had been cleaned in a methanol-water solution to remove any residual sodium on the tubing surface, then dried and stored in a plastic bag for approximately six (6) years before they were sodium reconditioned and subsequently sodium removed according to the test matrix (Table 3-1) defined in the present investigation.

In Figure 3-4, the microstructure of specimens of the $649^{\circ} \mathrm{C}\left(1200^{\circ} \mathrm{F}\right)$ sodium-exposed ( 5000 hours) Type 316 stainless stee 1 cladding material is shown. It is noted that massive intragranular carbide precipitation 
along the slip lines resulting from the severe cold work is evident in Figure 3-4(a). The cold-work effect apparently reduced significantiy the susceptibility of the material to sensitization. In Figure 3-4(b), the presence of a ferrite layer and the Mo- $\mathrm{Cr}$ intermetallic compound at the alloy-sodium interface is evident. Formation of these phases in the austenitic alloy surface is mainly due to the preferential depletion of nickel (austenite stabilizer) resulting from high temperature sodium exposure.

The microstructure of specimens of the $718^{\circ} \mathrm{C}\left(1325^{\circ} \mathrm{F}\right)$ sodiumexposed (5000 hours) Type 316 stainless steel cladding alloy is shown in Figure $3-5$. In contrast to the $649^{\circ} \mathrm{C}\left(1200^{\circ} \mathrm{F}\right)$ sodium-exposed structure, large amounts of sigma phase but less extensive carbide precipitation were observed in the $718^{\circ} \mathrm{C}\left(1325^{\circ} \mathrm{F}\right)$ sodium-exposed structure. The significant reduction in intragranular carbides is mainly due to the rapid growth of ferrite in the austenite matrix during the early exposure at $718^{\circ} \mathrm{C}\left(1325^{\circ} \mathrm{F}\right)$.

However, the ferrite phase in the Type 316 stainless steel matrix is known to be unstable after about 2000 hours at the temperature $\left(718^{\circ} \mathrm{C}\right)$ of interest, and it begins to decompose partially due to the formation of sigma phase. (3) Consequently, it is no surprise to see large amounts of sigma phase in this alloy after 5000 hours sodium exposure at $718^{\circ} \mathrm{C}$ $\left(1325^{\circ} \mathrm{F}\right)$. It is also important to note that a thicker ferrite layer $(\sim 25 \mu \mathrm{m})$ was formed in this case comparing to a ferrite layer of about $8 \mu \mathrm{m}$ formed in the $649^{\circ} \mathrm{C}\left(1200^{\circ} \mathrm{F}\right)$ sodium-exposed structure.

\subsubsection{Deposit-Bearing Type 304 Stainless Stee1}

The deposit-bearing Type 304 SS tube was originally an economizer tube (1iquid metal heat exchanger) of a nonisothermal dynamic sodium loop system. Consequently, it was subject to a temperature gradient across the tubing wall plus a temperature differential $(\Delta T)$ along its entire length. The temperature differential $(\Delta T)$ over the economizer 
length is graphically displayed in Figure 3-6. It is important to note that this graph assumes a linear heat transfer behavior for this economizer while in reality for a counter current heat exchanger, the temperature profile is nonlinear over the entire economizer length.

This economizer was exposed to sodium 20-25 ppm oxygen for 3547 hours. Thereafter it was sectioned with each length of tubing assigned a number to identify its original position within the economizer. Thirty specimens were fabricated for subsequent sodium reconditioning. These specimens were numbered according to their parent material which in turn had been identified as to location within the economizer as shown in Figure 3-6. Therefore, results on specimen characterization can be related to varying temperatures around the economizer.

Microstructural changes, resulting from the differences in thermal history along the economizer tube, have been characterized and are shown in Figure 3-7. A typical microstructure of specimens manufactured from the cold end $\left(\sim 454^{\circ} \mathrm{C}\right)$ is shown in Figure $3-7(\mathrm{a})$, while the microstructure representing the hot end $\left(2580^{\circ} \mathrm{C}\right)$ of the economizer tube is shown in Figure $3-7(\mathrm{~b})$. It is important to note that macrostructure resulting from the $454^{\circ} \mathrm{C}$ sodium exposure was not sensitized but the $580^{\circ} \mathrm{C}$ exposure caused the structure to be sensitized as indicated by the presence of intergranular carbides shown in Figure 3-7(b).

\subsection{Results on Sodium Reconditioning}

All specimens requiring sodium reconditioning, as defined in the test matrices of the current program, were completed in the sodium loop system MTL-4. A total of sixty (60) specimens, thirty (30) corroded Type 316 stainless steel cladding specimens exposed in the hot-leg section, and thirty (30) deposit-bearing Type 304 stainless steel specimens exposed in the cold-leg region of the sodium loop, were sodium 
re-exposed under the conditions given in Table 3-4. Typical surface appearances after the exposure are shown in Figures 3-8 and 3-9 for the Types 316 and 304 SS specimens, respectively. The presence of residual sodium on the specimen surface is evident in both cases.

Weight measurements were made on specimens exposed in loop Run \#2. After cleaning, the average weight loss for the seven specimens was $6.6 \pm 1.1$ milligrams. The weight change cannot be converted into corrosion rates due to the complex geometry of the specimens during the reconditioning. However, the control specimens which were exposed in the same loop yielded the following results:

$$
\begin{array}{ll}
\text { As-received Type } 316 \mathrm{SS} & \text { Weight loss }=0.33 \mathrm{mg} / \mathrm{dm}^{2} / \mathrm{hr}=1.45 \mathrm{mpy} \\
\text { Pre-exposed Type } 316 \mathrm{SS}
\end{array} \quad \begin{aligned}
& \text { Weight loss }=0.09 \mathrm{mg} / \mathrm{dm}^{2} / \mathrm{hr}=0.40 \mathrm{mpy}
\end{aligned}
$$

The pre-exposed control specimen had the same sodium pre-exposure history as the test samples. Therefore, its corrosion rate should reflect that of the test specimens under the loop conditions of Run 2.

The divergence of the two results is a natural sequence of the manner in which stainless steel corrodes in sodium. Initially, there is a high corrosion rate, during which time elements such as nickel ( $\mathrm{Ni}$ ) and chromium $(\mathrm{Cr})$ are preferentially leached from the surface. A steady state composition is eventually achieved and then the corrosion rate decreases. This was also observed in the two control specimens.

Visual examination after sodium reconditioning revealed no significant change in surface appearance of the test specimens. Destructive metallographic analysis on these specimens was unfeasible in order to carry out the subsequent water corrosion studies. However, metallographic characterization of the control specimens, made from the sodium pre-exposed materials, did not show any significant metallurgical or structural changes resulting from the additional sodium exposure during reconditioning. 
Table 3-1

Chemical Composition and Mechanical Properties of 20\% Cold-Worked Type 316 SS Tubing

\begin{tabular}{|c|c|c|c|c|c|c|c|}
\hline & \multirow[b]{2}{*}{ Element } & \multicolumn{3}{|c|}{$\begin{array}{l}\text { Vacuum Induction plus Consumable } \\
\text { Heat No. } 91695-1\end{array}$} & \multirow{2}{*}{$\begin{array}{l}0.2 \% \text { offset } \\
\text { Yield Strength* } \\
\quad(k s i)\end{array}$} & \multirow{2}{*}{$\begin{array}{l}\text { Ultimate } \\
\text { Tensile } \\
\text { Strength** } \\
\text { (ksi) }\end{array}$} & \multirow{2}{*}{$\begin{array}{c}\text { ASTM } \\
\text { Grain Size } \\
\text { (\#) }\end{array}$} \\
\hline & & $\begin{array}{c}\text { Supplier } \\
\text { Analysis } \\
w / 0\end{array}$ & $\begin{array}{l}\text { ARD } \\
\text { Check } \\
\text { Analysis } \\
\text { Bar Stock } \\
\text { w/o }\end{array}$ & $\begin{array}{l}\text { ARD } \\
\text { Check } \\
\text { Analysis } \\
\text { Tubing* } \\
\text { W/o }\end{array}$ & & & \\
\hline & $\mathrm{Fe}$ & Bal. & Bal. & 65.0 & 108.9 & 123.3 & \\
\hline & $\mathrm{Cr}$ & 16.44 & 16.89 & 16.4 & & & 9 \\
\hline & $\mathrm{Ni}$ & 13.75 & 14.04 & 13.7 & 115.0 & 123.3 & \\
\hline & Mo & 2.18 & 2.20 & 2.4 & & & \\
\hline \multirow[t]{13}{*}{$\vec{\omega}$} & $M_{n}$ & 1.47 & 1.34 & 1.4 & & & \\
\hline & $\mathrm{Si}$ & 0.52 & 0.58 & 0.53 & & & \\
\hline & $\mathrm{Cu}$ & 0.29 & 0.19 & 0.21 & & & \\
\hline & $\mathrm{Co}$ & 0.19 & 0.13 & 0.087 & & & \\
\hline & $\mathrm{llb}$ & & 0.007 & 0.018 & & & \\
\hline & $\mathrm{Ti}$ & & 0.005 & $<0.05$ & & & \\
\hline & $N$ & 0.020 & 0.0175 & 0.024 & & & \\
\hline & C & 0.044 & 0.0437 & 0.043 & & & \\
\hline & $\mathrm{P}$ & 0.017 & 0.014 & 0.010 & & & \\
\hline & $\mathrm{S}$ & 0.013 & 0.0188 & 0.012 & & & \\
\hline & B & 0.001 & 0.00065 & $2.6 \mathrm{ppm}$ & & & \\
\hline & $W$ & & & 0.13 & & & \\
\hline & * Ave & of Ana & yses from $t$ & rubing Lo & Heat & ts of $t$ & ings. \\
\hline
\end{tabular}


Table $3-2$

Chemical Composition And Mechanical Properties

of Annealed Type 304 SS

\begin{tabular}{|c|c|c|c|c|}
\hline \multicolumn{2}{|c|}{ Chemical Analysis } & \multicolumn{3}{|c|}{ Mechanical Properties } \\
\hline Element & $w / 0$ & $\begin{array}{c}0.2 \% \text { offset } \\
\text { Yieid Strength } \\
\text { (ksi) }\end{array}$ & $\begin{array}{c}\text { Ultimate Tensile } \\
\text { Strength } \\
(\mathrm{ksi})\end{array}$ & $\begin{array}{c}\text { Elongation, } \\
2 \text { in. } \\
(\%)\end{array}$ \\
\hline 0 & .05 & 36.3 & 90.6 & \\
\hline $\mathrm{Mn}$ & 1.65 & 36.3 & 90.6 & 53 \\
\hline$P$ & .013 & 39.9 & 92.4 & \\
\hline S & .011 & & & \\
\hline Si & .48 & & & \\
\hline $\mathrm{Ni}$ & 9.33 & & & \\
\hline $\mathrm{Cr}$ & 18.74 & & & \\
\hline $\mathrm{Fe}$ & Balance & & & \\
\hline
\end{tabular}


Table 3-3

Sodium Exposure History of Corroded Type 316 Stainless Steel

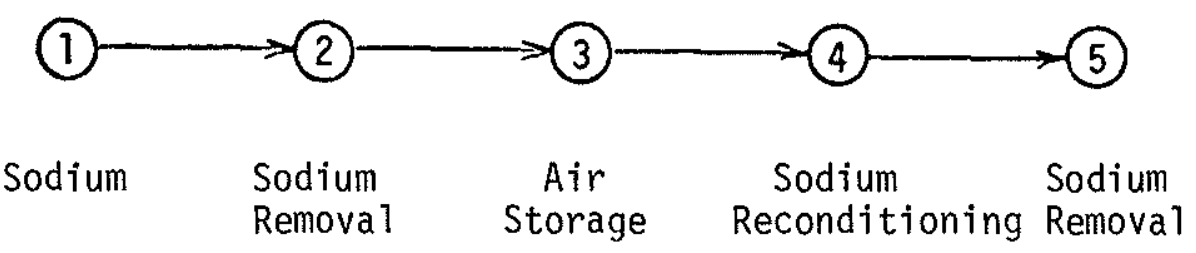

20\% Cold Worked, Type 316 Stainless Steel (Group 1)

(1) $718^{\circ} \mathrm{C}\left(1325^{\circ} \mathrm{F}\right) 2.1 \mathrm{~m} / \mathrm{s}(7 \mathrm{fps}),<10 \mathrm{ppm}$ oxygen, corrosion zone, $5000 \mathrm{hrs}$

(2) Methanol/Water Reactions

(3) Approximately 6 years

(4) $718^{\circ} \mathrm{C}\left(1325^{\circ} \mathrm{F}\right), 2.1 \mathrm{~m} / \mathrm{s}(7 \mathrm{fps}), 0.5-1.0 \mathrm{ppm}$ oxygen, corrosion zone, $.336 \mathrm{hrs}$

20\% Cold Worked, Type 316 Stainless Steel (Group 2)

(1) $649^{\circ} \mathrm{C}\left(1200^{\circ} \mathrm{F}\right), 2.1 \mathrm{~m} / \mathrm{s}(7 \mathrm{fps}),<10 \mathrm{ppm}$ oxygen, corrosion zone, $5000 \mathrm{hrs}$

(2) Methanol/Water Reactions

(3) Approximately 6 years

(4) $649^{\circ} \mathrm{C}\left(1200^{\circ} \mathrm{F}\right), 2.1 \mathrm{~m} / \mathrm{s}(7 \mathrm{fps}),<10 \mathrm{ppm}$ oxygen, corrosion zone, 336 grs

Note: 0xygen content of the sodium was determined by the mercury amalgamation procedure for Stage 1 and by vanadium wire equilibration for Stage 4. 
Table 3-4

SODIUM RECONDITION HISTORY OF THE TEST MATERIAL

\begin{tabular}{|c|c|c|c|c|c|}
\hline $\begin{array}{l}\text { Loop } \\
\text { Run }\end{array}$ & $\begin{array}{l}\text { Temp./No. } 0 \\
\text { Corroded Spec }\end{array}$ & f Specimens & $\frac{\text { Loop Ope }}{0 \times \text { vaph }}$ & - Cond. & Sodium Recond. \\
\hline 1 & $718^{\circ} \mathrm{C}\left(1325^{\circ} \mathrm{F}\right) / 8$ & & 0.31 & 2.1 & 334 \\
\hline 2 & $718^{\circ} \mathrm{C}\left(1325^{\circ} \mathrm{F}\right) / 7$ & & 0.50 & 2.1 & 330 \\
\hline 3 & $643^{\circ} \mathrm{C}\left(1190^{\circ} \mathrm{F}\right) / 8$ & $399^{\circ} \mathrm{C}\left(750^{\circ} \mathrm{F}\right) / 6$ & 0.60 & 2.1 & 335 \\
\hline 4 & $649^{\circ} \mathrm{C}\left(1200^{\circ} \mathrm{F}\right) / 7$ & $399^{\circ} \mathrm{C}\left(750^{\circ} \mathrm{F}\right) / 1$ & 0.59 & 2.1 & 340 \\
\hline 4 & & $399^{\circ} \mathrm{C}\left(750^{\circ} \mathrm{F}\right) / 7$ & 0.59 & 2.1 & 340 \\
\hline 6 & & $399^{\circ} \mathrm{C}\left(750^{\circ} \mathrm{F}\right) / 8$ & 0.50 & 2.1 & 340 \\
\hline 6 & & $399^{\circ} \mathrm{C}\left(750^{\circ} \mathrm{F}\right) / 8$ & 0.50 & 2.1 & 340 \\
\hline
\end{tabular}

* Measured by Vanadium Wire Equilibration Method. 

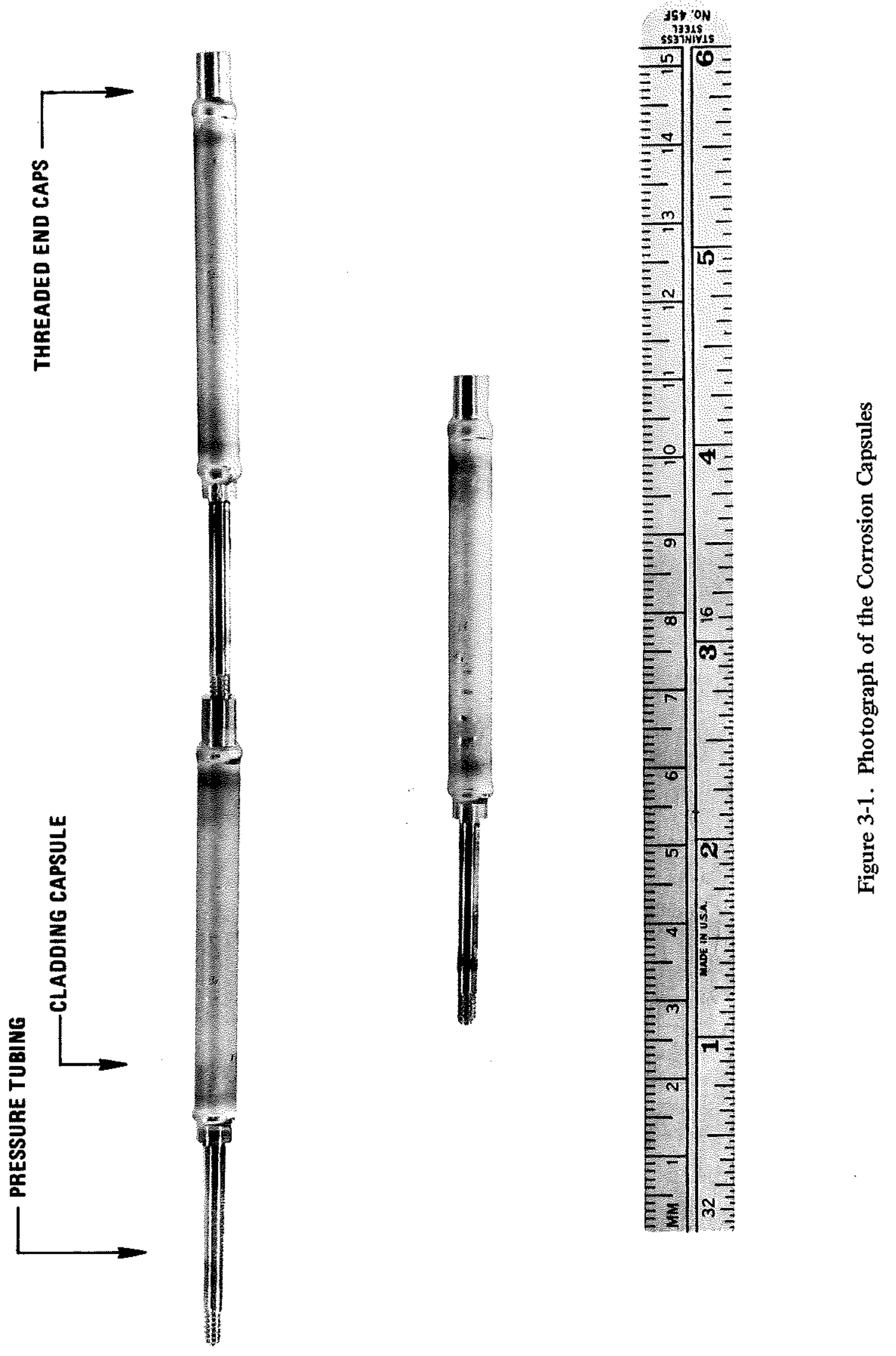
AS-FABRICATED SPECIMENS BEFORE

Na EXPOSURE IN MTL-4

Figure 3-2. Surface Appearance Of The Type 304 SS Specimens Before Sodium Exposure 


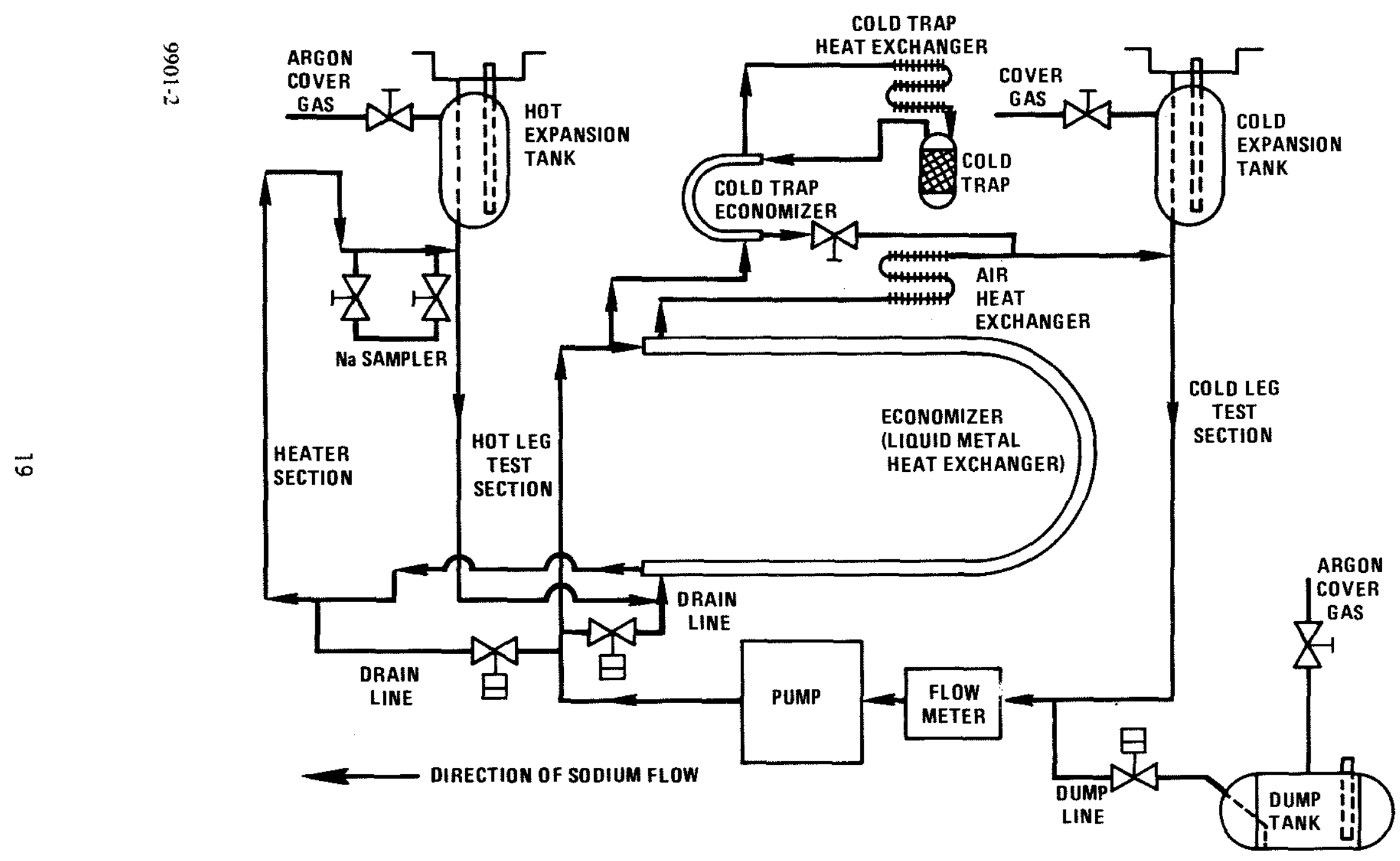

Figure 3-3. Schematic Drawing of an MTL System 

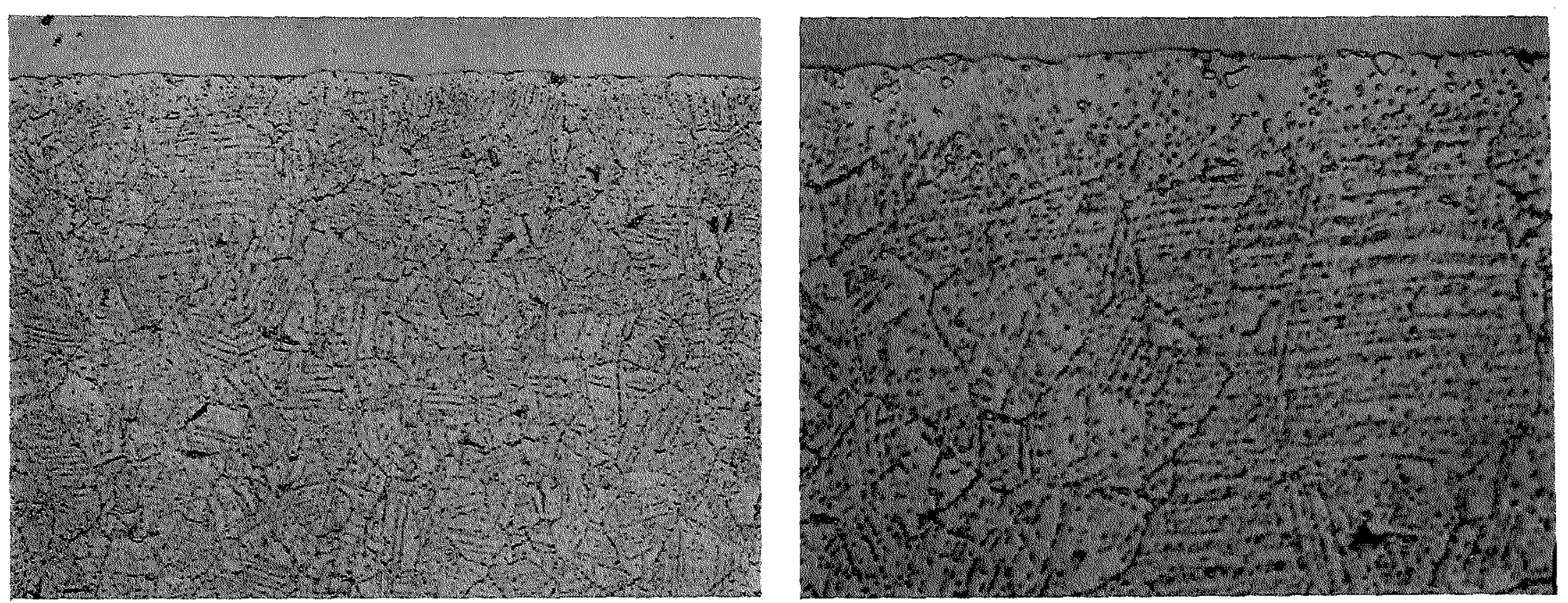

Figure 3-4. Microstructure Of Corroded 20\% Cold-Worked Type 316 SS (5300 Hours In $2.1 \mathrm{~m} / \mathrm{s}$ Sodium At $649^{\circ} \mathrm{C}$ )

(a) Intergranular Carbide Precipitation Along Slip Lines Within The Matrix. Etch: Gly/HCL/HNO $3.500 \times$

(b) Formation Of The Ferrite Layer And The Mo-Cr Intermetallic Compound. $1450 \mathrm{x}$ 


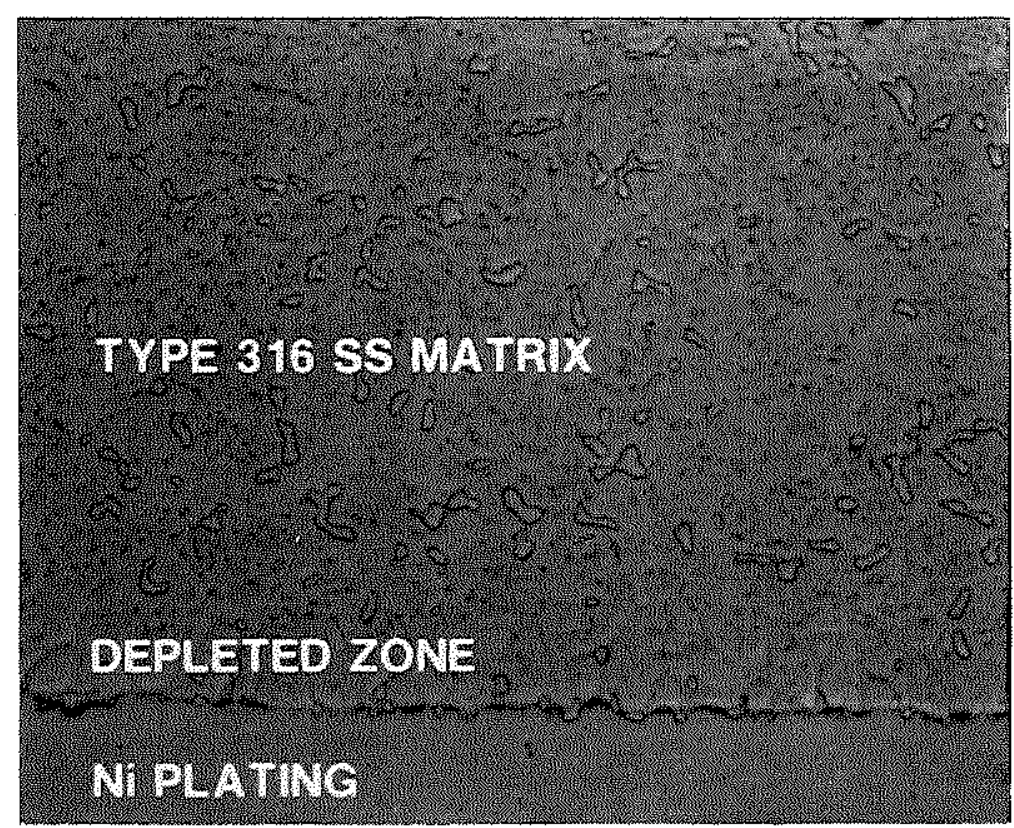

(a)

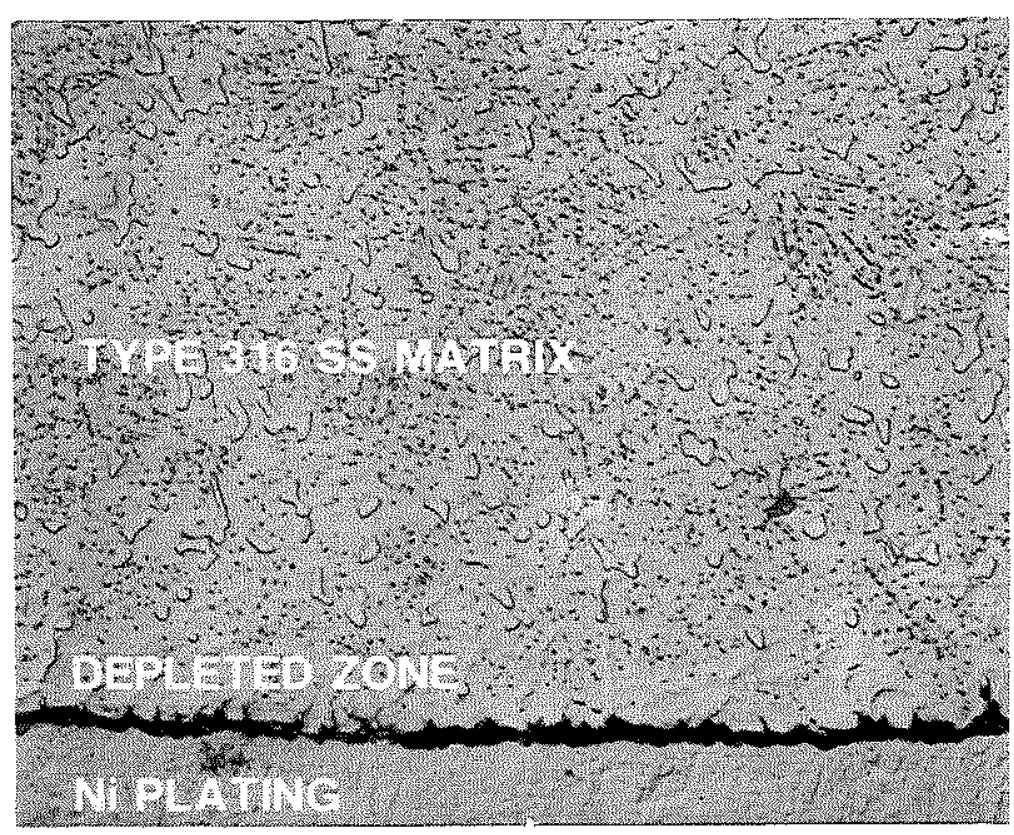

(b)

Figure 3-5. Microstructure Of Corroded 20\% Cold-Worked Type 316 SS (5300 Hours In $2.1 \mathrm{~m} / \mathrm{s}$ Sodium At $718^{\circ} \mathrm{C}$ ) (a) Sodium Removed By Alcohol/Water Reactions, Etch: Gly/HCL/HNO $3,500 \mathrm{x}$ (b) Sodium Removed By Steam/Argon Process, $500 \mathrm{x}$ 


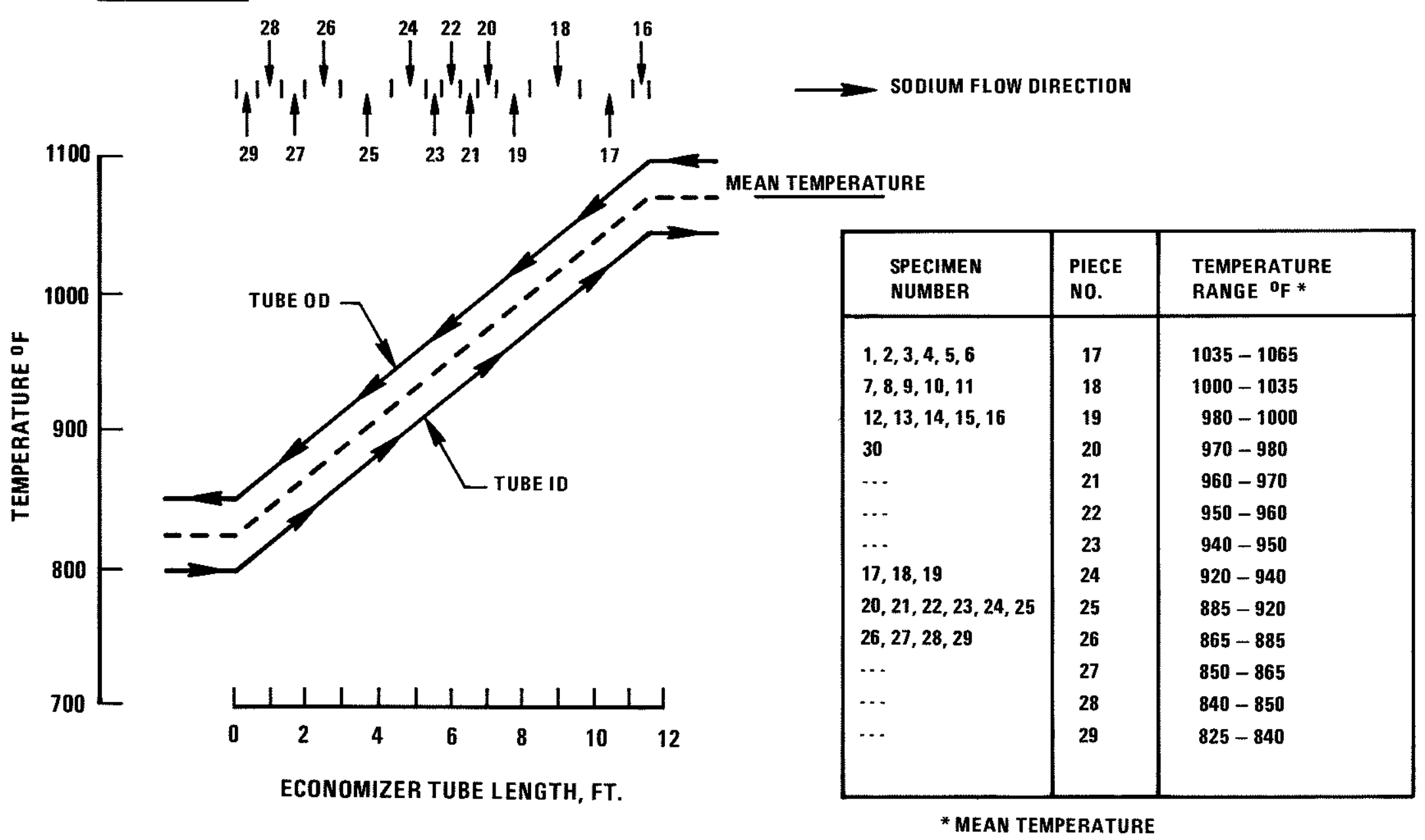

Figure 3-6. MTL-1-10 Economizer Tube Temperature Distribution 


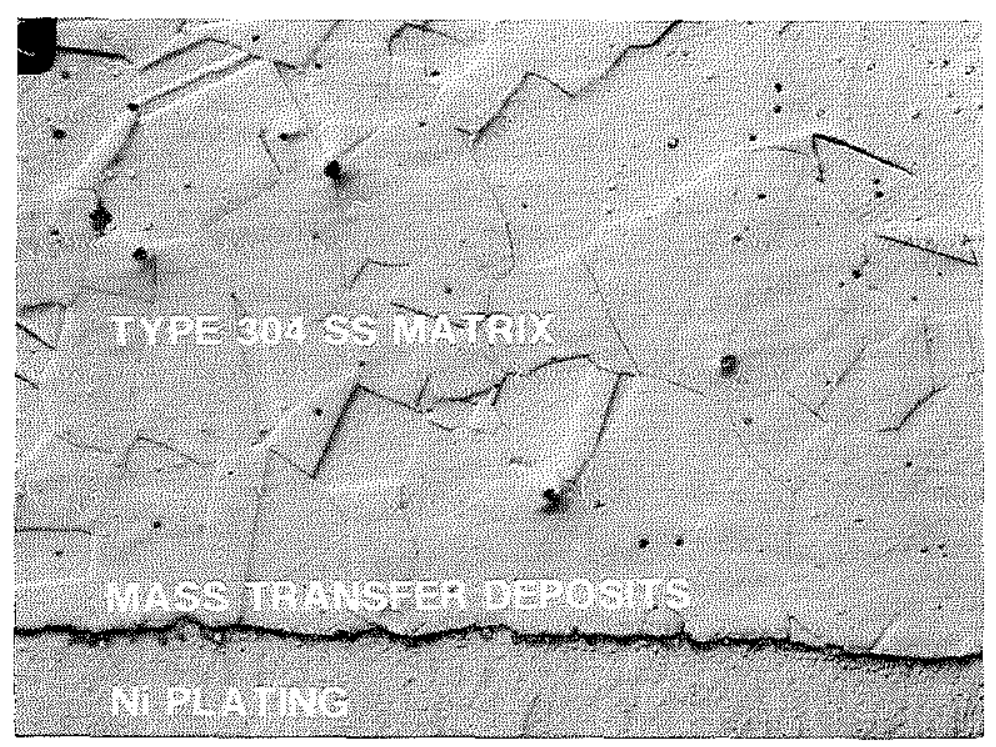

(a)

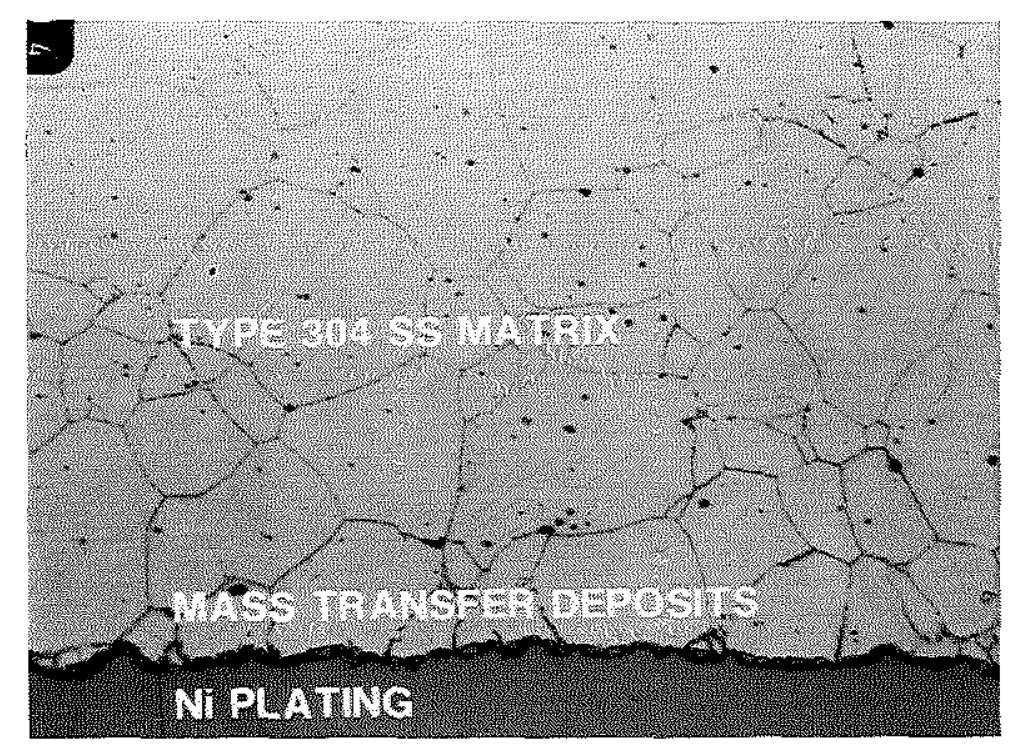

(b)

Figure 3-7. Microstructure Of Deposite-Bearing Type $304 \mathrm{SS}(\sim 3800$ Hours In $2.1 \mathrm{~m} / \mathrm{s} \mathrm{Sodium})$. Etch: Gly $/ \mathrm{HCL} / \mathrm{HNO}$ (a) Cold End Of The Economizer $\left(\sim 454^{\circ} \mathrm{C}\right) .500 \mathrm{x}$ (b) Hot End Of The Econimizer $\left(\sim 580^{\circ} \mathrm{C}\right) .500 \mathrm{x}$ 
号
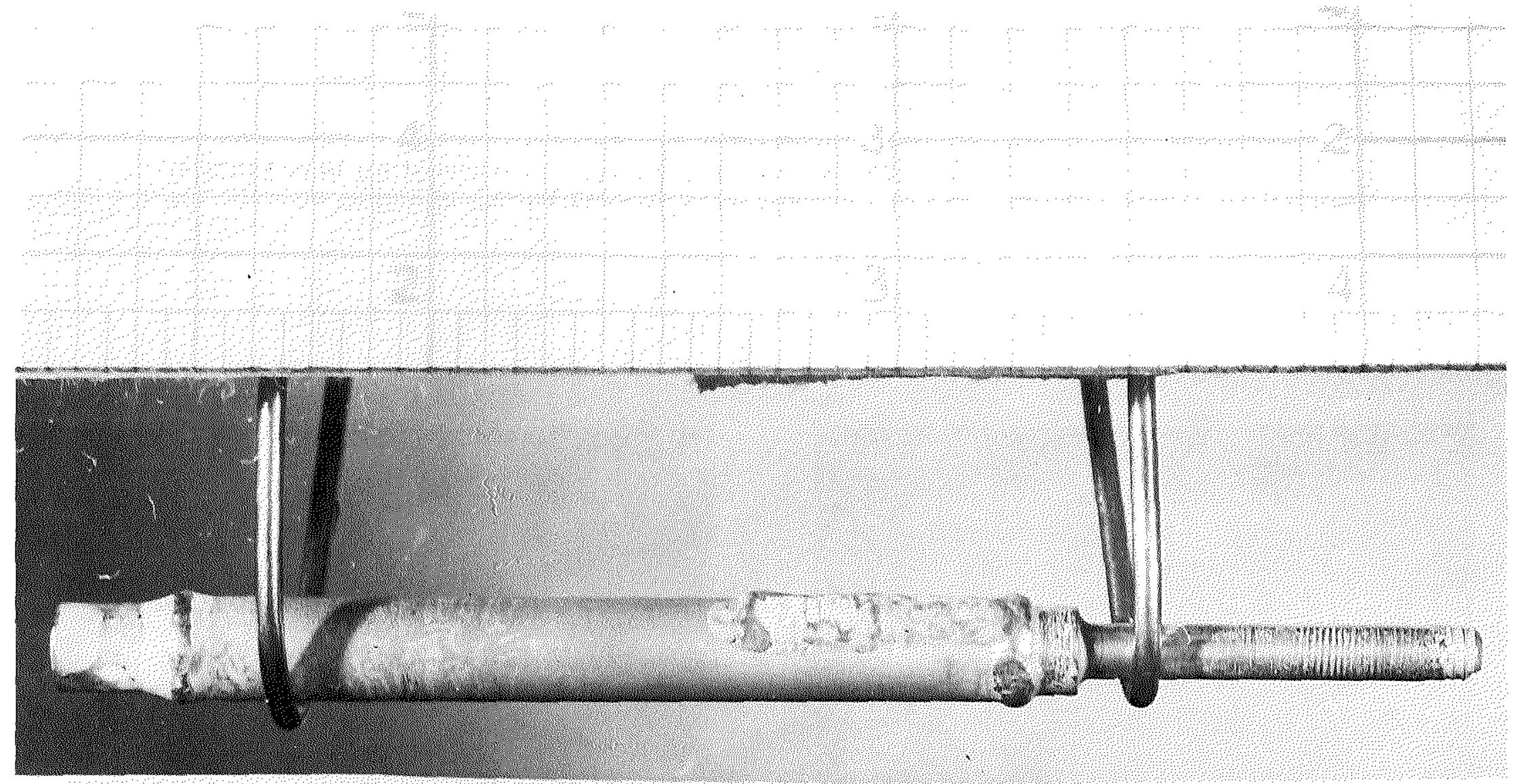

Figure 3-8. Typical Surface Condition Of The Type 316 SS Specimens After Sodium Exposure 


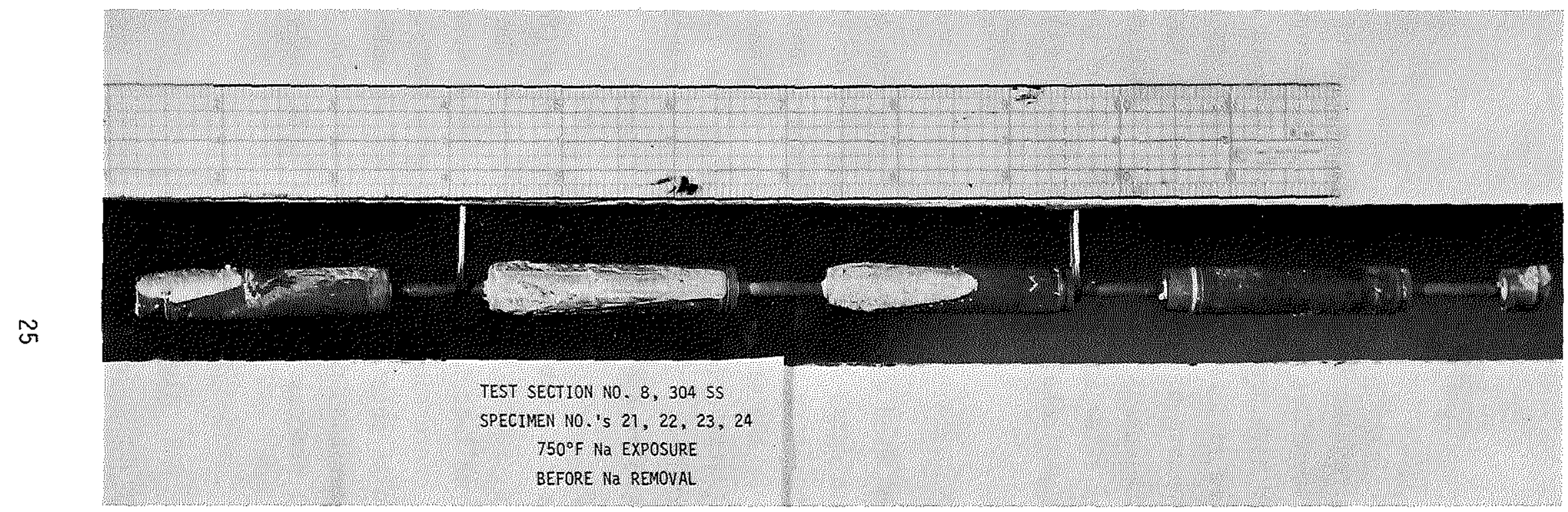

Figure 3-9. Typical Surface Condition Of The Type 304 SS Specimens After Sodium Exposure 


\subsection{SODIUM REMOVAL}

Practical considerations require the removal of the bulk of the residual sodium from LMFBR fuel assemblies prior to water pit storage. Various techniques and procedures have been developed and employed to remove sodium from sodium-exposed fast breeder reactor components and fuel assemblies. The main emphasis of the present investigation was to evaluate the effect on subsequent water corrosion of sodium-exposed prototypic cladding material after sodium removal by one of three sodium cleaning processes, namely alcohol, water vapor-argon (WVA), and steam/ argon (KNK) processes.

Al though alcohol has been used extensively to remove residual sodium from specimens and small containers, it has been generally utilized only for small items and on a laboratory scale. For efficiency and economic reasons, processes such as the water vapor/argon (WVA) and the steam/ argon (KNK) are more attractive in removing sodium from large scale LMFBR components and fuel assemblies. Consequently, the emphas is of the current program was mainly focused on the WVA and KNK processes.

Although the program was not intended to evaluate the efficiencies of the various cleaning methods, sodium ion $\left(\mathrm{Na}^{+}\right)$analyses of the alcohol and rinse water samples, as well as the hydrogen evolution data provided some qualitative information concerning the process efficiency. Based on this information and the results obtained on the effect on water corrosion behavior of the test materials, recommendations were made in choosing a reference sodium removal process for the LMFBR spent fuels as shown in Section 7 .

\subsection{Alcohol Process}

A total of eight (8) specimens, four (4) corroded Type 316 stainless steel 
specimens and four (4) deposit-bearing Type 304 stainless specimens, were sodium removed by the alcohol (Dowanol EB) process. The process control and the end of step requirements (EOSR) for this process are summarized in Table 4-1. The results obtained on sodium removal by this process are given in Table 4-2. Typical surface condition of the Types 316 and 304 stainless steel specimens after sodium removal by the alcohol process are shown in Figures $4-1$ and 4-2, respectively. It is evident that little or no changes occurred resulting from the cleaning process.

\subsection{Water Vapor/Argon Process}

Thirteen (13) corroded Type 316 stainless steel specimens and thirteen (13) deposit-bearing Type 304 stainless steel specimens were sodium cleaned by the WVA process as defined in Table 2-1. The process control and the end of step requirements (EOSR) for the WVA process are given in Table 4-3. The schematic diagram of the process and system used in sodium removal by this process is shown in Figure 4-3, and typical results obtained on sodium removal are given in Table 4-4. The effluent hydrogen monitored during the cleaning process for the corroded Type 316 stainless steel specimens is shown in Figure 4-4. As in the case of the alcohol process, the surface condition of the Types 316 and 304 specimens (shown in Figures 4-5 and 4-6, respectively) remained unchanged after the sodium removal operation.

\subsection{Steam/Argon Process}

A total of twenty-six (26) specimens, thirteen (13) specimens from each of the two test materials, were sodium cleaned by the KNK process. The process control and the end of step requirements (EOSR) for this process are given in Table 4-5. The schematic diagram of the process and system employed in sodium removal is shown in Figure 4-7. Typical results obtained on the 
corroded Type 316 stainless steel specimens during the sodium removal are given in Table 4-6. The hydrogen evolution monitored during the cleaning operation is shown in Figure 4-8. The surface conditions are shown in Figures 4-9 and 4-10 for the corroded Type 316 stainless steel specimens and the deposit-bearing Type 304 stainless steel specimens, respectively. In contrast to the specimens cleaned by the WVA process, the higher operating temperature of the steam/argon process $\left(140\right.$ to $160^{\circ} \mathrm{C}$ in the case of the KNK process versus $60-90^{\circ} \mathrm{C}$ in the case of the WVA process) caused surface discoloration by the formation of an adherent dark film.

\subsection{Summary}

Al1 specimens requiring sodium removal as defined in the test matrices of the current program have been sodium cleaned. The sodium removal history of the test specimens are summarized in Table 4-7. Visual examination after sodium removal indicated that little or no change of the specimen surface resulted from the alcohol and/or the WVA process; however, surface darkening and film formation was observed in specimens sodium cleaned by the KNK process, apparently due to the higher operating temperature.

Analyses of the hydrogen data indicated that some conversion of sodium to oxide may have occurred during glove box handling prior to the sodium removal operation. In addition, based on the weight change and the hydrogen effluent concentration observed, the maximum rate of sodium reaction was estimated to be $0.13 \mathrm{gram} / \mathrm{min}$ for the Type 304 stainless steel specimen. Furthermore, based on the percentage of residual sodium removed at a given time, shown in Figure 4-9, it is obvious that the KNK process is more expedient than the WVA process. 
Table 4-1

Dowanol EB Process Control and End-of-Step Requirements

\begin{tabular}{|c|c|c|c|c|c|c|c|c|c|}
\hline \multicolumn{3}{|c|}{ Inlet Fluid } & \multicolumn{3}{|c|}{ Component Temp.,${ }^{\circ} \mathrm{C}$} & \multicolumn{2}{|c|}{$\mathrm{H}_{2}$ Effluent, v/o } & \multicolumn{2}{|c|}{ General Effluent EOSR } \\
\hline Step & Type & Temp.,${ }^{\circ} \mathrm{C}$ & Control & Max. & EOSR & $\operatorname{Max}$ & EOSR & $\begin{array}{c}\text { Specific } \\
\text { Conductivity } \\
\text { umho/cm }\end{array}$ & $\mathrm{Na}+, \mathrm{ppm}$ \\
\hline 1. EB-I & $\begin{array}{l}\text { Dowanol EB+ } \\
\text { Ar Sparge }\end{array}$ & Ambient & -- & 95 & Ambient & 3.5 & $\leq 0.01$ & $n m(2)$ & (3) \\
\hline 2. EB-II & $\begin{array}{l}\text { Dowanol } \mathrm{EB}+5 \\
\mathrm{~V} / \mathrm{O} \mathrm{H}_{2} \mathrm{O}-\mathrm{Ar}\end{array}$ & Ambient & -- & 95 & Ambient & 3.5 & $\leq 0.01$ & $\mathrm{~nm}$ & (3) \\
\hline 3. EB-III & $\begin{array}{l}\text { Dowanol } \mathrm{EB}+10 \\
\mathrm{~V} / \mathrm{O} \mathrm{H}_{2} \mathrm{O}-\mathrm{Ar}\end{array}$ & Ambient & $\cdots$ & 95 & Ambient & 3.5 & $\leq 0.01$ & $\mathrm{~nm}$ & (3) \\
\hline 4. EB-IV & $\begin{array}{l}\text { Dowanol } \mathrm{EB}+2 \mathrm{O} \\
\mathrm{V} / \mathrm{O} \mathrm{H}_{2} \mathrm{O}-\mathrm{Ar}\end{array}$ & Ambient & $\cdots$ & 95 & Ambient & 3.5 & $\leq 0.001$ & $\mathrm{~nm}$ & (3) \\
\hline $\begin{array}{l}\text { 5. } \mathrm{H}_{2} \mathrm{O}(4) \\
\text { fi]l } \\
\text { and } \\
\text { cycle }\end{array}$ & $\mathrm{H}_{2} \mathrm{O}+\mathrm{Ar}$ Sparge & Ambient & --- & 95 & Ambient & 3.5 & $\leq 0.00\}$ & (4) & (4) \\
\hline 6. $\mathrm{H}_{2} \mathrm{O}$ cycles $(5)$ & $\mathrm{H}_{2} \mathrm{O}$ & $80 \pm 5$ & --- & 95 & $80 \pm 5$ & $\mathrm{~nm}$ & $\mathrm{~nm}$ & $\leq 20$ & $\leq 1$ \\
\hline 7. Dry ${ }^{(6)}$ & Ar & $100 \pm 5$ & -- & 105 & $100 \pm 5$ & $\mathrm{~nm}$ & $\mathrm{~nm}$ & $\mathrm{~nm}$ & $\mathrm{~nm}$ \\
\hline
\end{tabular}

(1) EOSR - End-of-Step Requirement

(2) $\mathrm{nm}$ - not monitored

(3) Determine the total volume of inlet fluid cycled in each step and obtain sample for Nat analysis for information.

(4) Grade B water to be analyzed as blank before fill. Total volume of water cycled to be determined. Cycle to be continued until the Na+ content and specific conductance are constant ( $\pm 10 \%$ ) for a 2-hour cycle period. Final Na+ content to be determined for information.

(5) The test section or vessel is to be refilled with fresh Grade B water and cycled at the temperature indicated. Refilling and cycling to be continued until the EOSR for specific conductance and Na+ content are met. Each cycle is to be analyzed for Nat content.

(6) Drying is to be continued until the effluent argon dewpoint is $\leq 15^{\circ} \mathrm{C}$. 
Table 4-2

Results on Sodium Removal by the Alcohol Process

\begin{tabular}{|c|c|c|c|c|c|}
\hline Inlet & Time, hours & $\begin{array}{l}\text { Flow } \\
\text { gpm }\end{array}$ & $\begin{array}{l}\operatorname{Max} . \\
\text { Temp. }{ }^{\circ} \mathrm{C} \\
\end{array}$ & $\begin{array}{c}\text { Max. } \\
\underline{H}_{2}, p \mathrm{pm}\end{array}$ & $\begin{array}{c}\text { Volume } \\
\text { Circulated, gal. }\end{array}$ \\
\hline \multirow[t]{2}{*}{$E B-A r$} & 4 & 0 & 26 & no data & 3 \\
\hline & 1.5 & 2.5 & 35 & $<10$ & $"$ \\
\hline $\begin{array}{c}\mathrm{EB}-5 \mathrm{~V} / \mathrm{O} \\
\mathrm{H}_{2} \mathrm{O}-\mathrm{Ar}\end{array}$ & 0.5 & 2.5 & 30 & 12 & " \\
\hline $\begin{array}{c}\mathrm{EB}+10 \mathrm{~V} / \mathrm{O} \\
\mathrm{H}_{2} \mathrm{O}-\mathrm{Ar}\end{array}$ & 0.25 & 2.5 & 30 & $<10$ & $"$ \\
\hline $\begin{array}{c}\mathrm{EB}+20 \mathrm{~V} / \mathrm{O} \\
\mathrm{H}_{2} \mathrm{O}-\mathrm{Ar}\end{array}$ & 0.25 & 2.5 & 30 & $<10$ & $"$ \\
\hline $\mathrm{H}_{2} \mathrm{O}-\mathrm{Ar}$ & 5 & 2.5 & 20 & $<10$ & 4 \\
\hline $\mathrm{H}_{2} \mathrm{O}$ & 6.5 & 2.5 & 80 & -- & $"$ \\
\hline
\end{tabular}

Sodium ion analyses of the alcohol and rinse water samples indicated that approximately 0.23 grams of residual sodium ions removed from the eight specimens processed by Dowanol EB. 
Table 4-3 WVA Process Control and End-of-Step Requirements

\begin{tabular}{|c|c|c|c|c|c|c|c|c|c|}
\hline \multicolumn{3}{|c|}{ Inlet Fluid } & \multicolumn{3}{|c|}{ Component Temp., ${ }^{\circ} \mathrm{C}$} & \multicolumn{2}{|c|}{$\mathrm{H}_{2}$, Effluent; $\mathrm{v} / \mathrm{O}$} & \multicolumn{2}{|c|}{ General Effluent EOSR ${ }^{(1)}$} \\
\hline Step & Type & Temp. , ${ }^{\circ} \mathrm{C}$ & Control & Max. & EOSR & Max. & EOSR & $\begin{array}{r}\text { Specific } \\
\text { Conductiyity } \\
\mu \mathrm{mho} / \mathrm{cm}\end{array}$ & $\mathrm{Na}^{+}, \mathrm{ppm}$ \\
\hline 1. Preheat & Ar & $60 \pm 5$ & $60 \pm 5$ & 65 & $60 \pm 5$ & \multicolumn{2}{|c|}{ background } & $\mathrm{nm}^{(2)}$ & $\mathrm{nm}$ \\
\hline 2. WVA $1^{(3)}$ & $\mathrm{Ar}+1-3 \mathrm{v} / \mathrm{O} \mathrm{H}_{2} \mathrm{O}$ & $60 \pm 5$ & $60 \pm 5$ & 95 & $60 \pm 5$ & 3.5 & $\leq 0.7$ & $\mathrm{~nm}$ & $\mathrm{~nm}$ \\
\hline 3. WVA II & $\mathrm{Ar}+5-10 \mathrm{~V} / \mathrm{O}_{2} \mathrm{H}_{2} \mathrm{O}$ & $60 \pm 5$ & $60 \pm 5$ & 95 & $60 \pm 5$ & 3.5 & $\leq 0.1$ & $\mathrm{~nm}$ & $\mathrm{~nm}$ \\
\hline 4. WVA III ${ }^{(4)}$ & $\begin{array}{r}\mathrm{Ar}+15-20 \mathrm{v} / \mathrm{O} \\
\mathrm{H}_{2} \mathrm{O}\end{array}$ & $80 \pm 5$ & $80 \pm 5$ & 95 & $80 \pm 5$ & 3.5 & $\leq 0.001$ & $\mathrm{~nm}$ & (5) \\
\hline $\begin{array}{l}\text { 5. } \mathrm{H}_{2} \mathrm{O} \mathrm{fill} \\
\text { and cycle }\end{array}$ & $\mathrm{Ar}+\mathrm{H}_{2} \mathrm{O}$ & Ambient & -- & 95 & Ambient & 3.5 & $\leq 0.001$ & (6) & (6) \\
\hline 6. $\mathrm{H}_{2} \mathrm{O}$ & $\mathrm{H}_{2} \mathrm{O}$ & $80 \pm 5$ & -- & 95 & $80 \pm 5$ & $\mathrm{~nm}$ & $\mathrm{~nm}$ & $\leq 20$ & $\leq 1$ \\
\hline 7. Drying $(8)$ & Ar & $100 \pm 5$ & $-\cdots$ & 105 & $100 \pm 5$ & $\mathrm{~nm}$ & $\mathrm{~nm}$ & $\mathrm{~nm}$ & $\mathrm{~nm}$ \\
\hline
\end{tabular}

(1) EOSR - End-of-Step Requirement

(2) $\mathrm{nm}$ - not monitored

(3) If during WVA phases, Max. values of component temperature or effluent $\mathrm{H}_{2}$ are reached, water vapor injection is to be stopped and the $\mathrm{Ar}$ flow increased until the temperature and effluent $\mathrm{H}_{2}$ values have decreased to an acceptable level before proceeding. Changes in inlet fluid temperature and component temperature control may also be used to aid this process.

(4) Before starting this step, remove hygrometer probe. Maximum operating temperature for probe is $70^{\circ} \mathrm{C}$.

(5) Condensate from WNA steps to be collected, volume measured, and sampled for $\mathrm{Na}^{+}$concentration for information.

(6) Grade B water to be analyzed as blank before fill. Total volume of water cycled to be determined. Cycle to be continued until the $\mathrm{Na}^{+}$content and specjfic conductance are constant $( \pm 10 \%)$ for a 2 -hour cycle period. Final $\mathrm{Na}^{+}$content to be determined for information.

(7) After drain of initial fill, the vessel is to be refilled with fresh Grade $B$ water and cycled at temperature indicated. Refilling and cycling to be continued until the EOSR for specific conductance and $\mathrm{Na}^{+}$content are met. Each cycle is to be analyzed for $\mathrm{Na}^{+}$content.

(8) Drying is to be continued until the effluent argon dewpoint is $\leq 15^{\circ} \mathrm{C}$. 
Table $\quad 4-4$

Results on Sodium Removal by the WVA Process

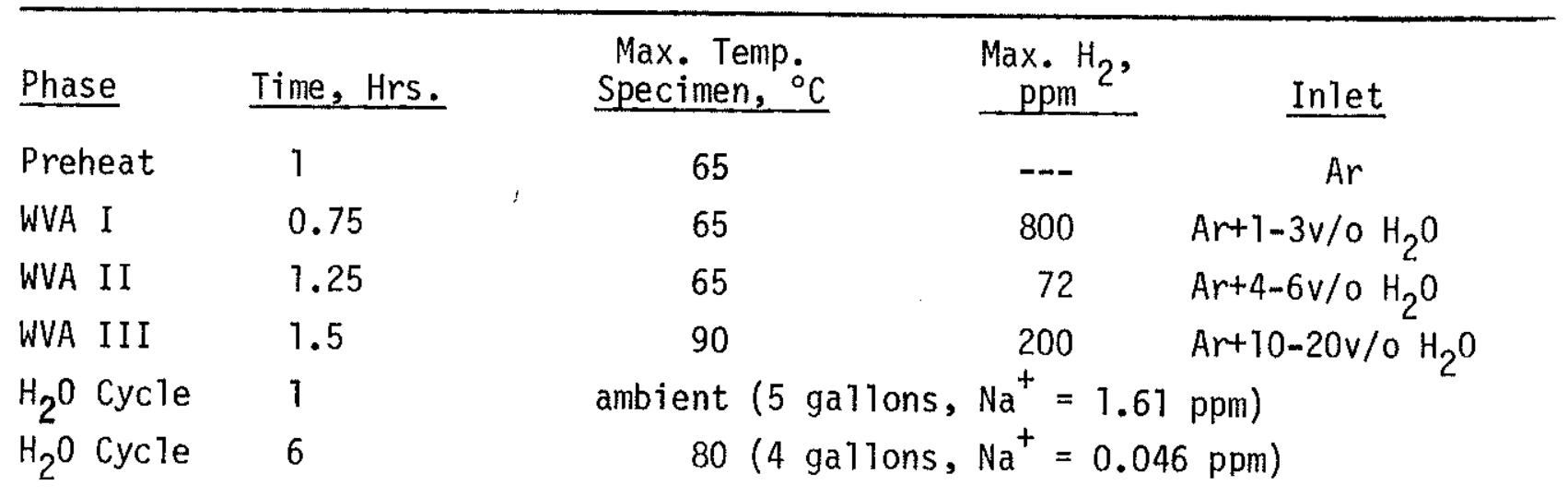


Table 4-5 Steam/Argon Process Control and End-of-Step Requirements

\begin{tabular}{|c|c|c|c|c|c|c|c|c|c|}
\hline \multicolumn{3}{|c|}{ Inlet Fluid } & \multicolumn{3}{|c|}{ Component Temp., ${ }^{\circ} \mathrm{C}$} & \multicolumn{2}{|c|}{$\mathrm{H}_{2}$ Effluent, v/o } & \multicolumn{2}{|c|}{ General Effluent $\operatorname{EOSR}^{(1)}$} \\
\hline Step & Type & $\begin{array}{l}\text { Temp. } \\
{ }^{\circ} \mathrm{C}\end{array}$ & Control & Max. & EOSR & Max. & EOSR & $\begin{array}{c}\text { Specific } \\
\text { Conductivity } \\
\text { umho/cm }\end{array}$ & $\mathrm{Na}^{+}, \mathrm{ppm}$ \\
\hline 1. Preheat & Ar & $100 \pm 5$ & $160 \pm 5$ & 165 & $160 \pm 5$ & \multicolumn{2}{|c|}{ background } & $n m^{(2)}$ & $\mathrm{nm}$ \\
\hline 2. Steam/Ar $(3)$ & Steam/Ar & $100 \pm 5$ & $160 \pm 5$ & 180 & $160 \pm 5$ & 1.0 & 0.001 & $\mathrm{~nm}$ & (4) \\
\hline 3. $\mathrm{H}_{2} \mathrm{O}$ fill ${ }_{\text {cycle }}^{(5)}$ & $\mathrm{H}_{2} \mathrm{O}+\mathrm{Ar}$ & 100 & $\cdots$ & 180 & 100 & 1.0 & 0.001 & (5) & (5) \\
\hline 4. $\mathrm{H}_{2} \mathrm{O}$ cycles ${ }^{(6)}$ & $\mathrm{H}_{2} \mathrm{O}$ & Ambient & $\cdots$ & 180 & Ambient & $\mathrm{nm}$ & $\mathrm{nm}$ & $\leq 20$ & $\leq 1$ \\
\hline 5. Drying $(7)$ & Ar & Ambient & --- & Ambient & Ambient & $\mathrm{nm}$ & $\mathrm{nm}$ & $\mathrm{nm}$ & $\mathrm{nm}$ \\
\hline
\end{tabular}

(1) EOSR - End-of-Step Requirement

(2) Nm - Not monitored

(3) See Steps 4.10.5.1 through 4.10.5.5.

(4) Condensate from Steam/Ar phase is to be collected, volume measured, and sampled for $\mathrm{Na}^{+}$concentration for information.

(5) Grade B water blank to be analyzed for $\mathrm{Na}+, \mathrm{pH}$, and specific conductance. Total volume of water cycled to be determined. Cycle to be continued until $\mathrm{Na}$ + content and specific conductance are constant $( \pm 10 \%)$ for a 2 -hour cycle period. Final $\mathrm{Na}$ to be determined for information.

(6) After drain of initial fill, the test section is to be refilled with fresh Grade B water and cycled. Refilling and cycling to be continued until the EOSR for specific conductance and $\mathrm{Na}+$ content are met. Each cycle is to be analyzed for $\mathrm{Na}+$ content.

(7) Drying is to be continued until the effluent argon dewpoint is $\leq 15^{\circ} \mathrm{C}$. 
Table 4-6

Resu1ts for Steam/Argon Process on 20\% Cold-Worked Type 316 SS Specimens No. 2-7

$\stackrel{\omega}{\perp}$

\begin{tabular}{|c|c|c|c|c|c|}
\hline Step & $\begin{array}{l}\text { Inlet } \\
\text { Fluid } \\
\end{array}$ & Time, Hours & $\begin{array}{c}\text { Maximum } \\
\text { Observed } \\
\text { Component } \mathrm{T},{ }^{\circ} \mathrm{C}\end{array}$ & $\begin{array}{l}\text { Maximum } \\
\text { Effluent } \\
\mathrm{H}_{2}, \mathrm{v} / \mathrm{O} \\
\end{array}$ & Remarks \\
\hline Preheat & $\mathrm{Ar}-140^{\circ} \mathrm{C}$ & 3 & 140 & background & $\begin{array}{l}\text { Ar flow } 5 c \mathrm{fm}, 0_{2}<2 \mathrm{v} / \mathrm{o}, \\
\text { all end steps achieved }\end{array}$ \\
\hline Steam/Argon & $\begin{array}{l}\text { Arts team } \\
-140^{\circ} \mathrm{C}\end{array}$ & 2 & 140 & 0.23 & $\begin{array}{l}\text { Ar flow } 1 \text { scfm, terminal } \\
\mathrm{H}_{2} 6 \mathrm{ppm} \text {, all end steps } \\
\text { achieved. One ( } 11 \text { liter } \\
\text { condensate collected } \\
\left(9.2 \times 10^{-4} \mathrm{M} \mathrm{Na}^{+}\right)\end{array}$ \\
\hline $\begin{array}{l}\text { Hot water } \\
\text { cycle }\end{array}$ & $\mathrm{H}_{2} \mathrm{O}-90^{\circ} \mathrm{C}$ & $\begin{array}{l}1 \\
5\end{array}$ & $\begin{array}{l}30-90 \\
30-90\end{array}$ & $\begin{array}{l}\text { none } \\
\text { none }\end{array}$ & $\begin{array}{l}151 \text { iters deionized water } \\
\text { circulated } \\
341 \text { liters deionized water } \\
\text { circulated } \\
\text { Terminal specific conduc- } \\
\text { tance was } 6-9 \mu \mathrm{mho} / \mathrm{cm}\end{array}$ \\
\hline $\begin{array}{l}\text { Water } \\
\text { cycle }\end{array}$ & $\mathrm{H}_{2} \mathrm{O}-\mathrm{Amb}$ & 1 & 15 & $\begin{array}{l}\text { not } \\
\text { measured }\end{array}$ & $\begin{array}{l}341 \text { iters deionized water } \\
\text { circulated, terminal } \\
\text { specific conductance was } \\
8 \mu \mathrm{mho} / \mathrm{cm} \text {, terminal } \mathrm{Na}^{+} \\
<0.1 \mathrm{ppm}\end{array}$ \\
\hline Drying & $\mathrm{Ar}-110^{\circ} \mathrm{C}$ & 1 & 105 & $\begin{array}{l}\text { not } \\
\text { measured }\end{array}$ & $\begin{array}{l}\text { Ar flow } 0.1 \mathrm{cfm} \text {, terminal } \\
\text { dew point } 15^{\circ} \mathrm{C}\end{array}$ \\
\hline
\end{tabular}


Table 4-7

Sodium Cleaning History of Cladding Specimens

\begin{tabular}{|c|c|c|c|c|c|}
\hline $\begin{array}{l}\text { Cladding } \\
\text { Iype }(1,2)\end{array}$ & $\begin{array}{c}M T L-4 \\
\text { Run No. }\end{array}$ & $\begin{array}{c}\text { Test } \\
\text { Section }\end{array}$ & $\begin{array}{c}\text { Sodium } \\
\text { Re-Exposure }\end{array}$ & $\begin{array}{l}\text { Specimen } \\
\text { Nos. } 3 \text { ( }) \\
\end{array}$ & $\begin{array}{l}\text { Sodium } \\
\text { Removal } \\
\text { Process } \\
\end{array}$ \\
\hline $316 \mathrm{CW}$ & 1 & 1 & $\begin{array}{c}718^{\circ} \mathrm{C}\left(1325^{\circ} \mathrm{F}\right) \\
200 \mathrm{hrs} .\end{array}$ & $\begin{array}{c}23 \\
24-30\end{array}$ & $\begin{array}{c}\text { Dowanol EB } \\
\text { WVA }\end{array}$ \\
\hline $316 \mathrm{ch}$ & 2 & 2 & $\begin{array}{c}718^{\circ} \mathrm{C}\left(1325^{\circ} \mathrm{F}\right) \\
200 \mathrm{hrs} .\end{array}$ & $16-22$ & Steam/Argon \\
\hline $316 \mathrm{CH}$ & 3 & 3 & $\begin{array}{c}649^{\circ} \mathrm{C}\left(1200^{\circ} \mathrm{F}\right) \\
335 \mathrm{hrs} .\end{array}$ & $\begin{array}{r}8,9 \\
10-15\end{array}$ & $\begin{array}{c}\text { Dowano] EB } \\
\text { WVA }\end{array}$ \\
\hline $316 \mathrm{CW}$ & 4 & 4 & $\begin{array}{c}649^{\circ} \mathrm{C}\left(1200^{\circ} \mathrm{F}\right) \\
336 \mathrm{hrs} .\end{array}$ & $\begin{array}{c}1 \\
2-7\end{array}$ & $\begin{array}{l}\text { Dowanol EB } \\
\text { Steam/Argon }\end{array}$ \\
\hline 304 SS & 3 & $5 / 6$ & $\begin{array}{c}399^{\circ} \mathrm{C}\left(750^{\circ} \mathrm{F}\right) \\
335 \mathrm{hrs} .\end{array}$ & $25-30$ & Steam/Argon \\
\hline 304 SS & 4 & $7 / 8$ & $\begin{array}{c}399^{\circ} \mathrm{C}\left(750^{\circ} \mathrm{F}\right) \\
336 \mathrm{hrs} .\end{array}$ & $\begin{array}{c}17 \\
18-24\end{array}$ & $\begin{array}{c}\text { WVA } \\
\text { Steam/Argon }\end{array}$ \\
\hline 304 SS & 5 & $9 / 10$ & $\begin{array}{c}399^{\circ} \mathrm{C}\left(750^{\circ} \mathrm{F}\right) \\
336 \text { hrs. }\end{array}$ & $\begin{array}{r}9-12 \\
13-16\end{array}$ & $\begin{array}{c}\text { Dowanol EB } \\
\text { WVA }\end{array}$ \\
\hline 304 SS & 6 & $11 / 12$ & $\begin{array}{c}399^{\circ} \mathrm{C}\left(750^{\circ} \mathrm{F}\right) \\
336 \mathrm{hrs} .\end{array}$ & $1-8$ & WVA \\
\hline
\end{tabular}

(1) $20 \%$ cold-worked Type 316 SS tubing $0.230^{\prime \prime} 0.0 \times 0.015^{\prime \prime} \mathrm{W}$

(2) 304 SS tubing $0.437^{\prime \prime} 0 . D . \times 0.020^{\prime \prime} \mathrm{W}$

(3) Specimen numbers listed per orientation from sodium inlet to sodium outlet in MTL-4. 


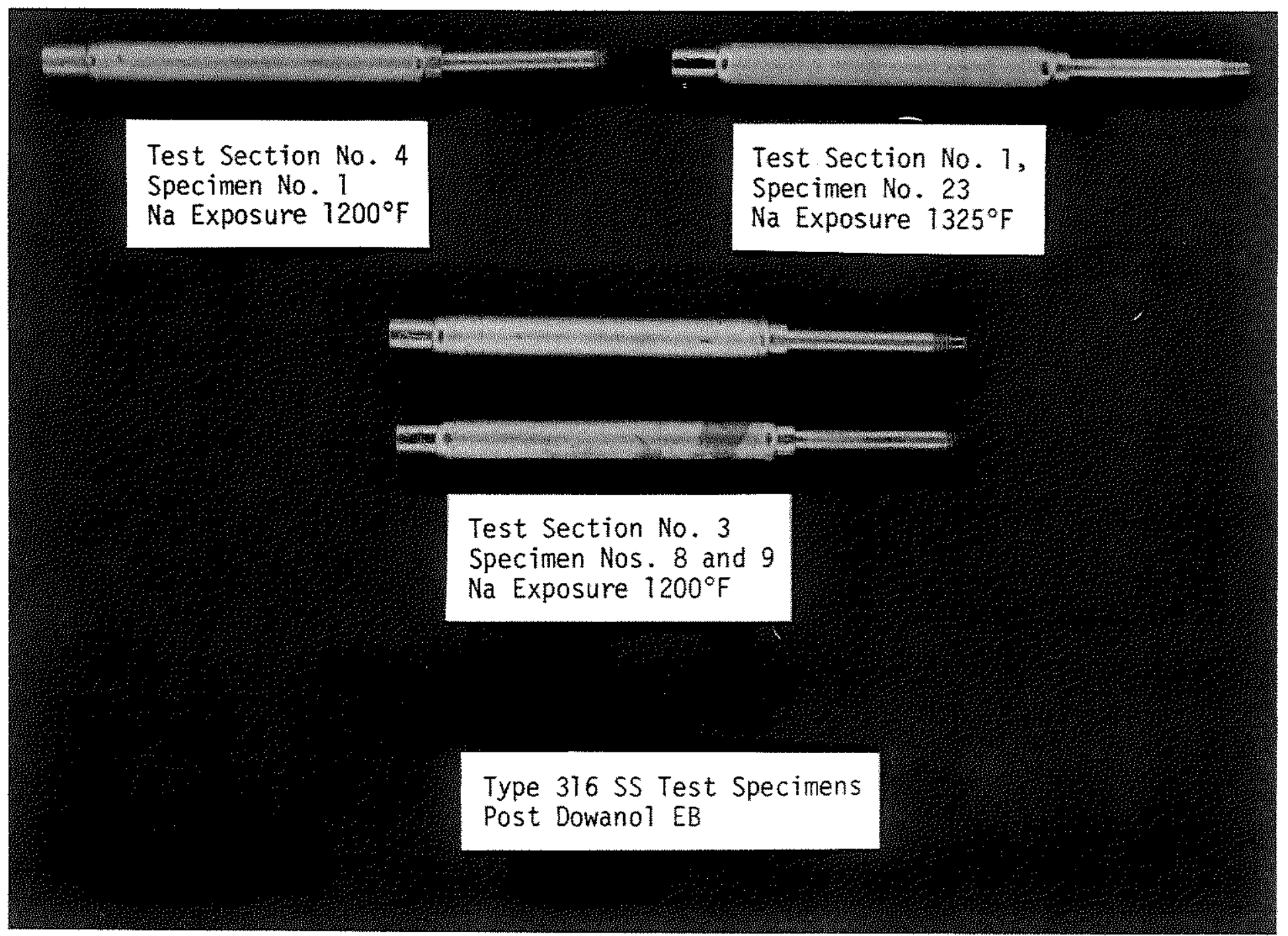

Figure 4-1. Typical Surface Condition Of The Type 316 SS Specimens After Sodium Removal By The Alcohol Process 

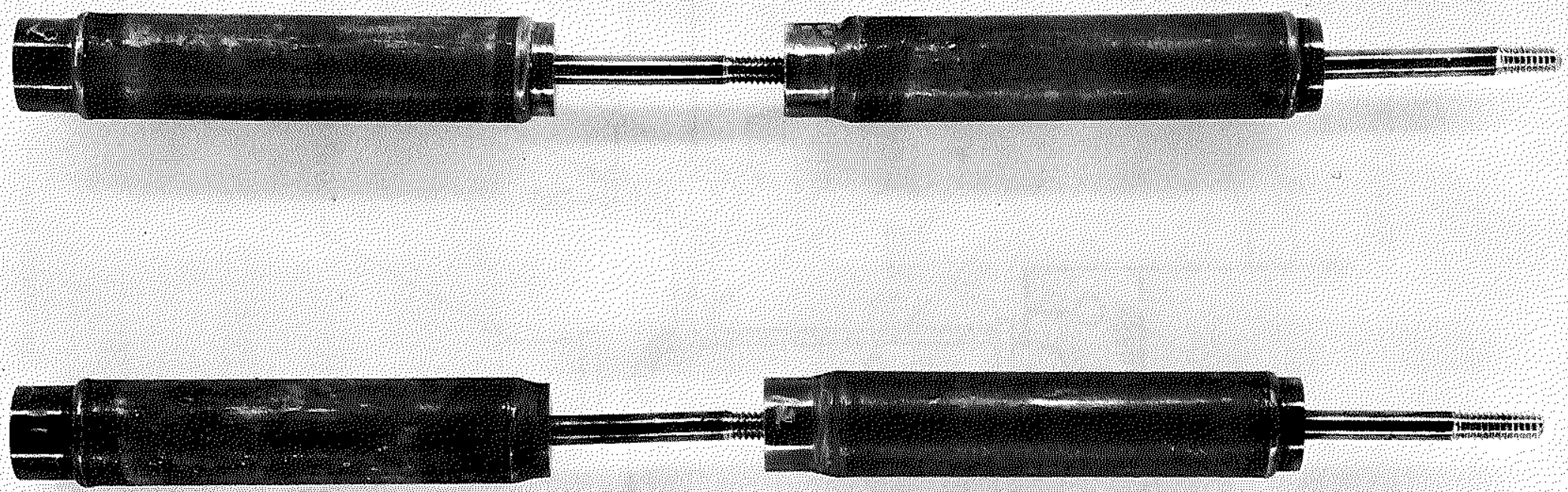

Test Section No. 9, 304 SS, Specimen Nos. $9,10,11,12$

$\mathrm{Na}$ Exposure $750^{\circ} \mathrm{F}$

Post Dowanol EB

Figure 4-2. Typical Surface Condition Of The Type 304 SS Specimens After Sodium Removal By The Alcohol Process 


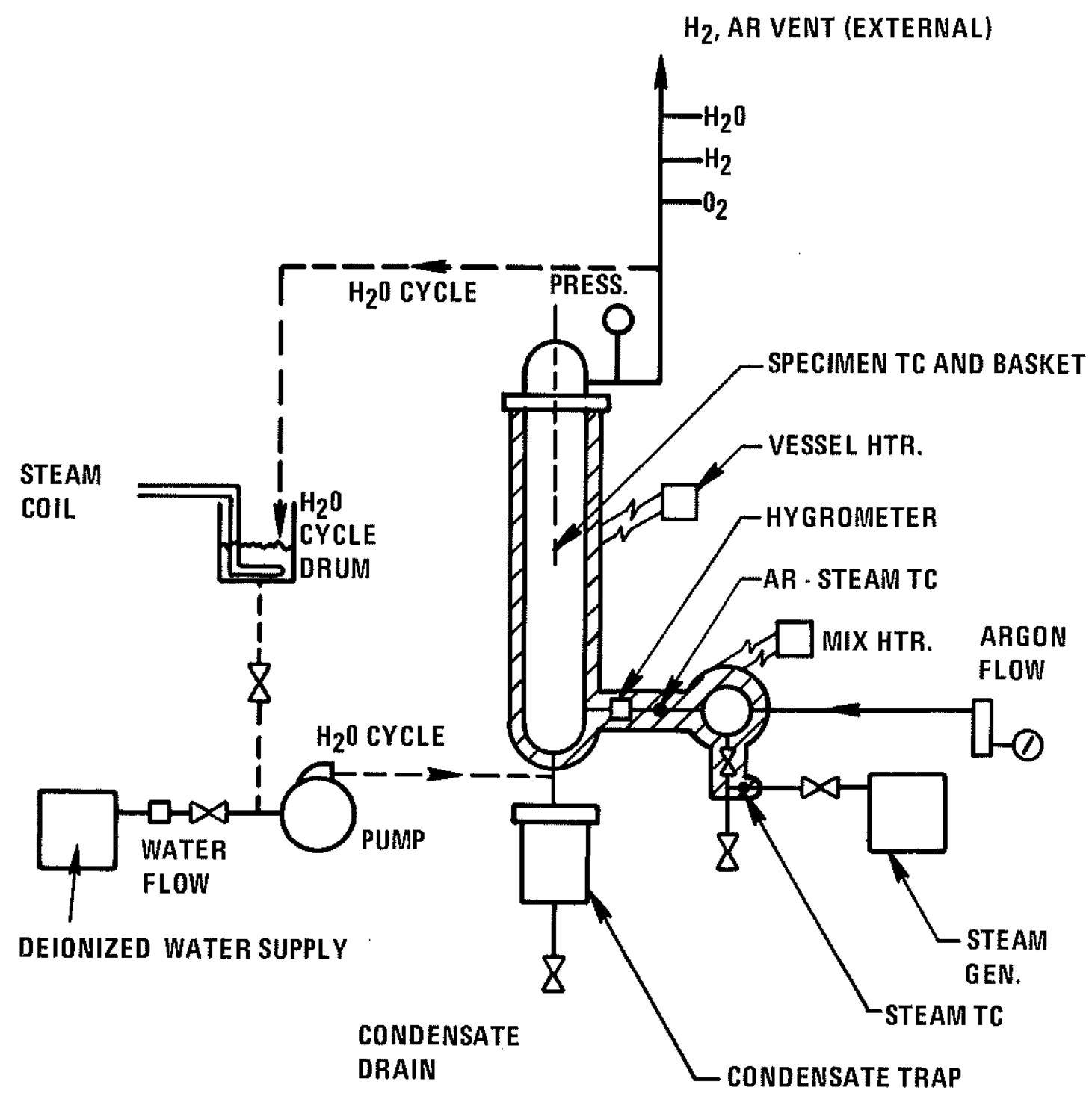

Figure 4r3. Schematic of WVA for Cladding Specimens from MTL - 4 Runs 1 and 3 


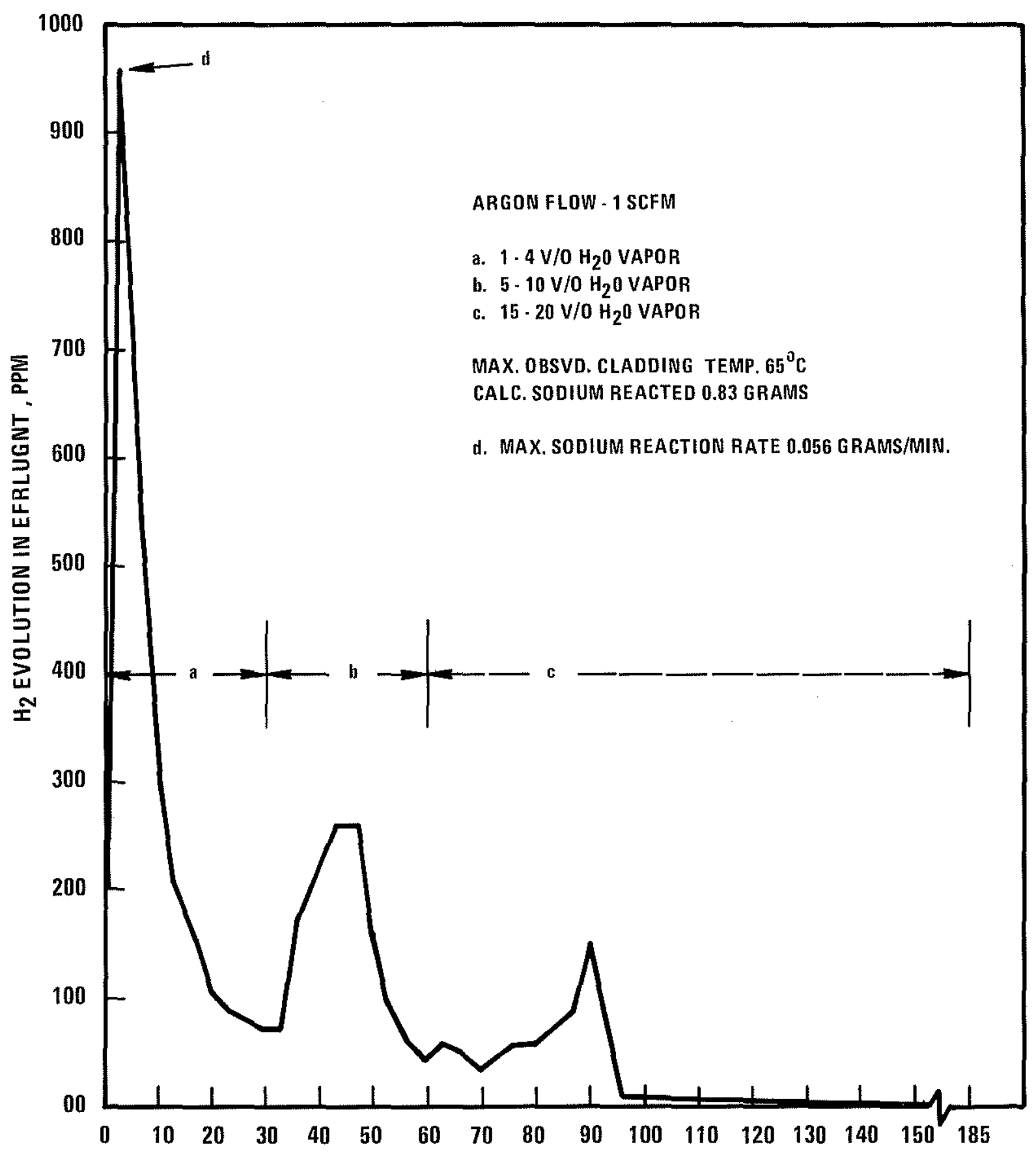

Figure 4-4. Effluent Hydrogen During WVA Process For Cladding Specimens from Sections 1 and 3, MTL - 4 Runs 1 and 3 
$\frac{10}{0}$

B
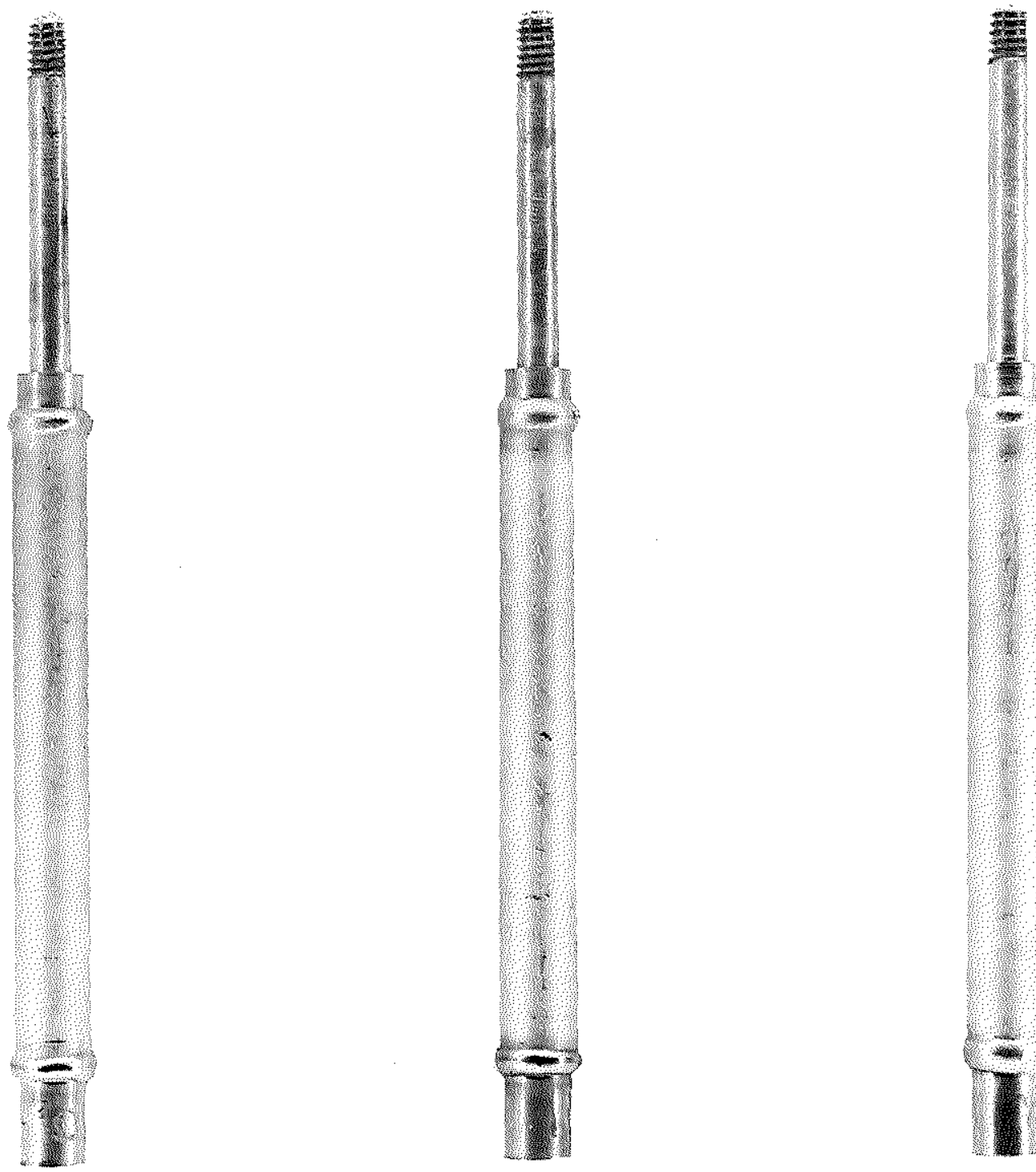

Figure 4-5. Typical Surface Condition Of. The Type 316 SS Specimens After Sodium Removal By The Water Vapor/Argon Process 


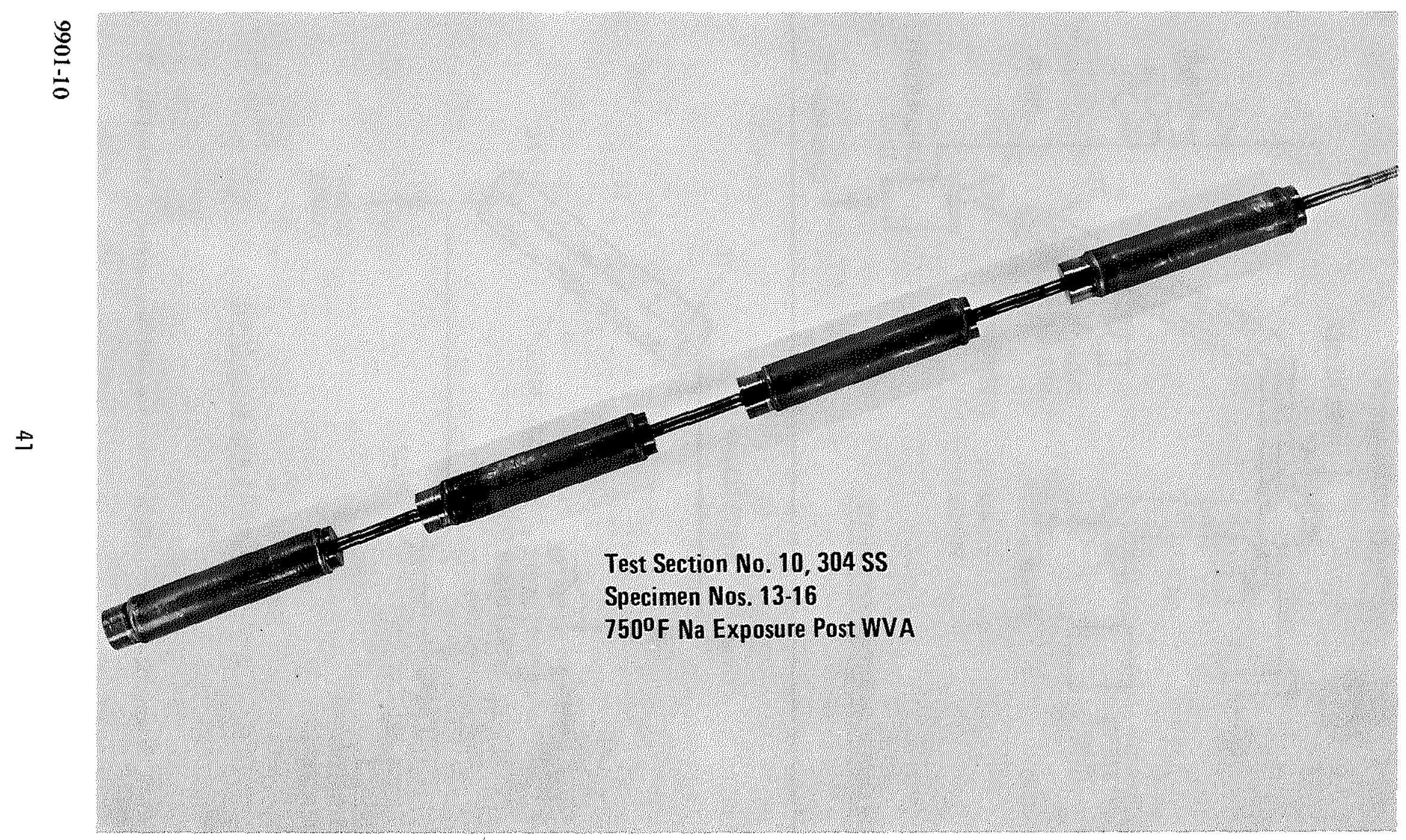

Figure 4-6. Typical Surface Condition Of The Type 304 SS Specimens After Sodium Removal By The Water Vapor/Argon 

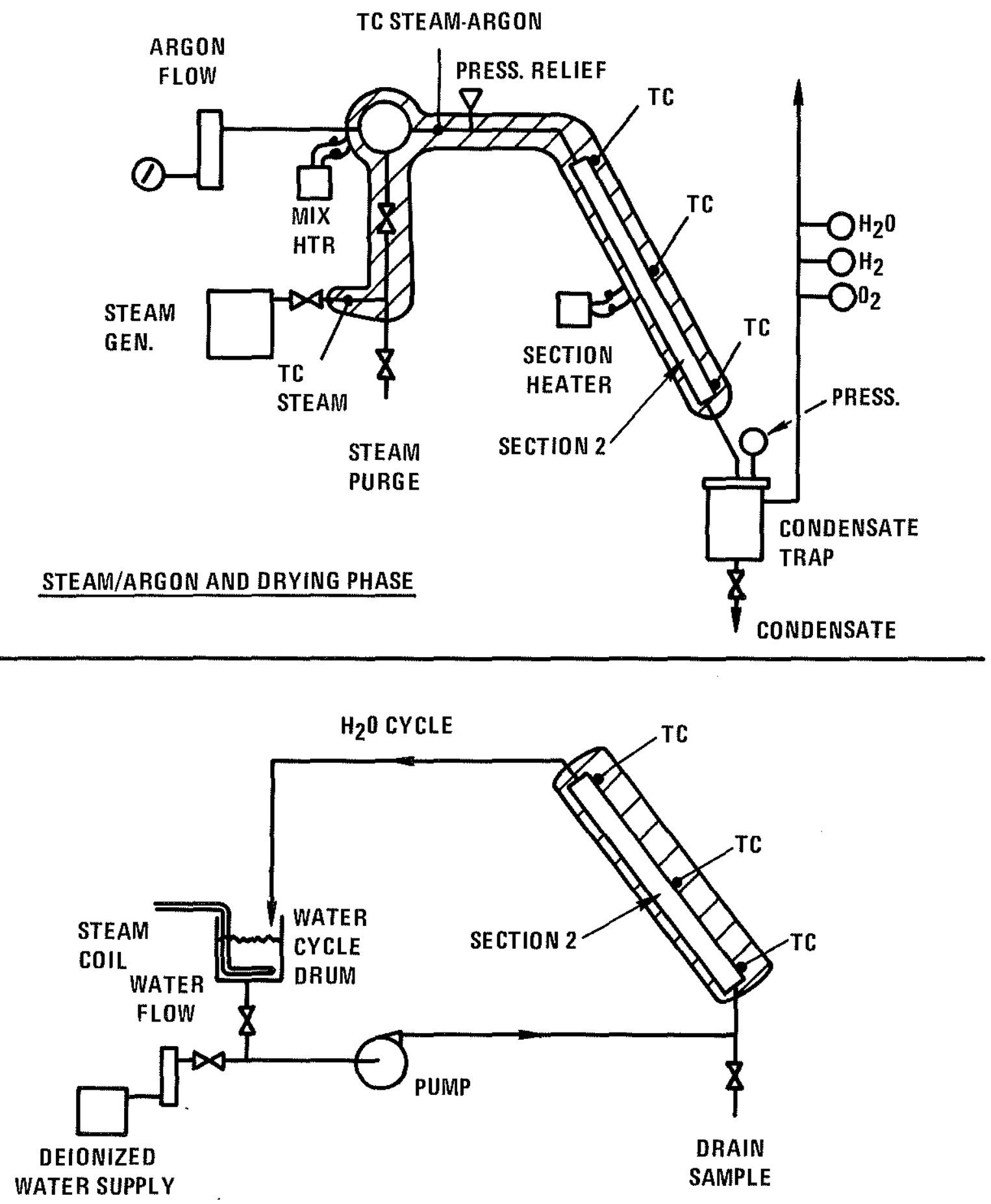

WATER FILL AND RINSE PHASE

Figure 4-7. Schematic of Steam/Argon Process for Cladding Section 2, MTL-4 Run 2 $9901-9$ 


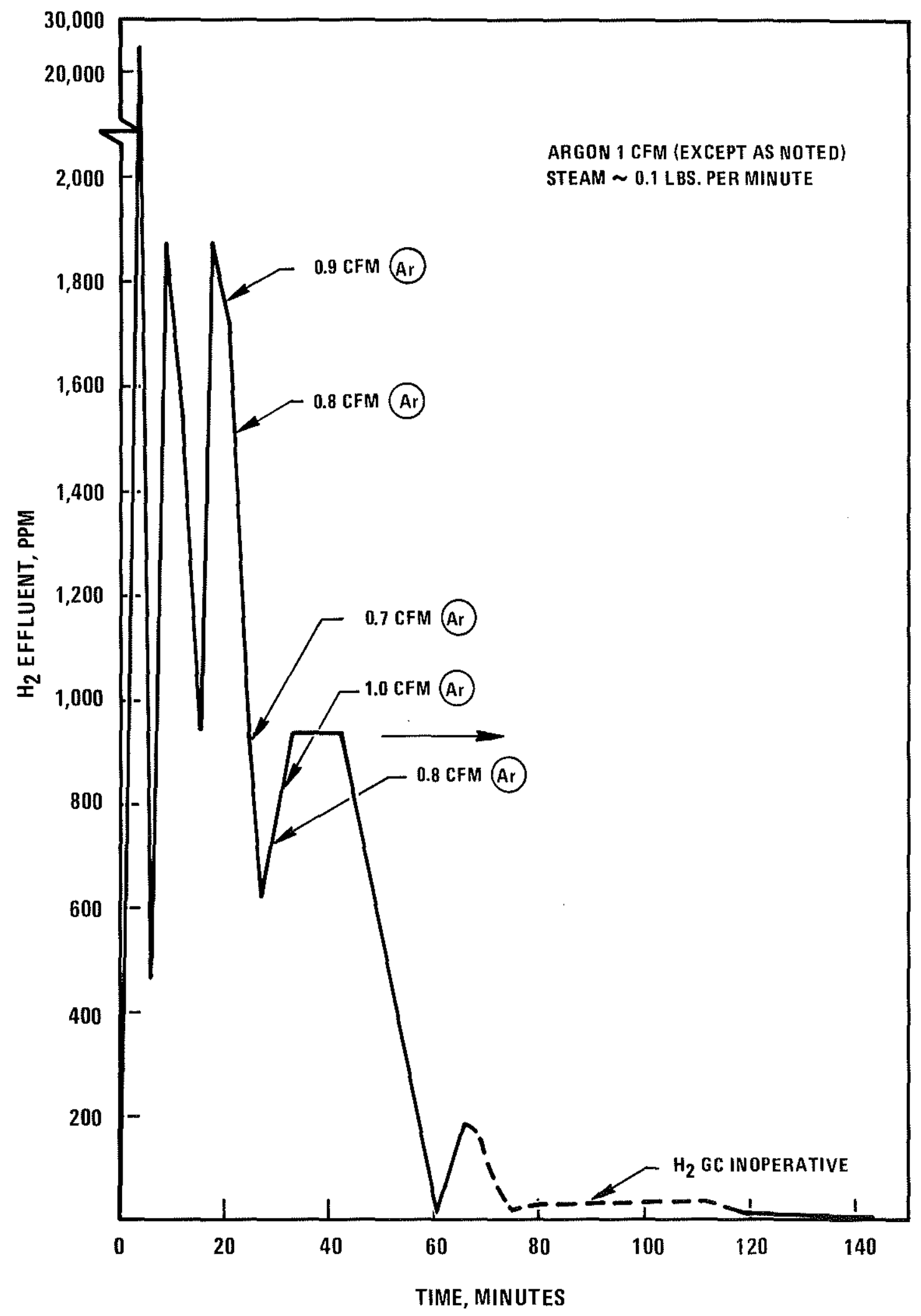

Figure 4-8. Effluent Hydrogen During Steam/Argon Process for Type 316SS Cladding Specimens 9901-3 
$\frac{8}{2}$

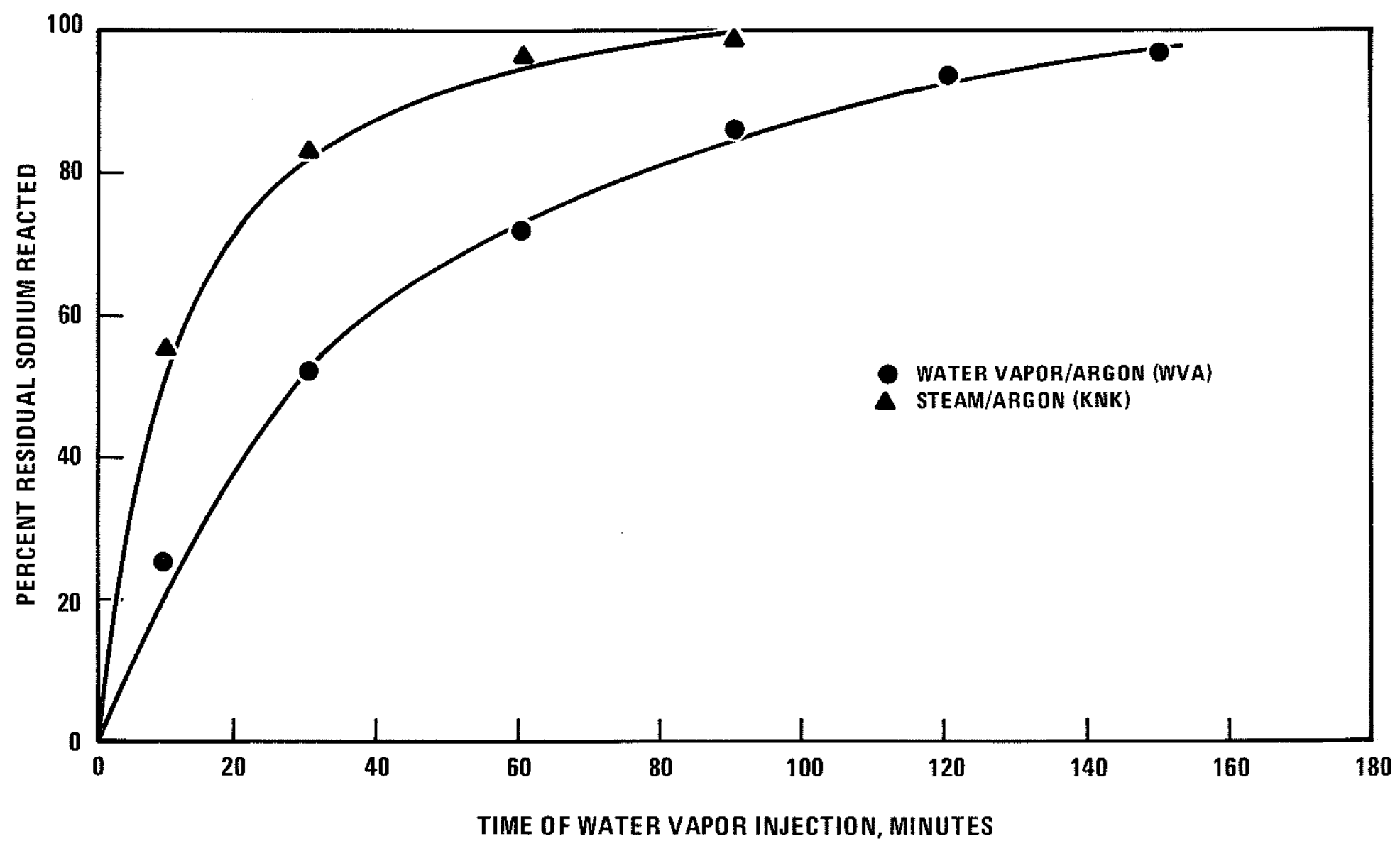

Figure 4-9. Comparison of Sodium Removal Expediency 
$\frac{\wp}{\stackrel{0}{*}}$

아

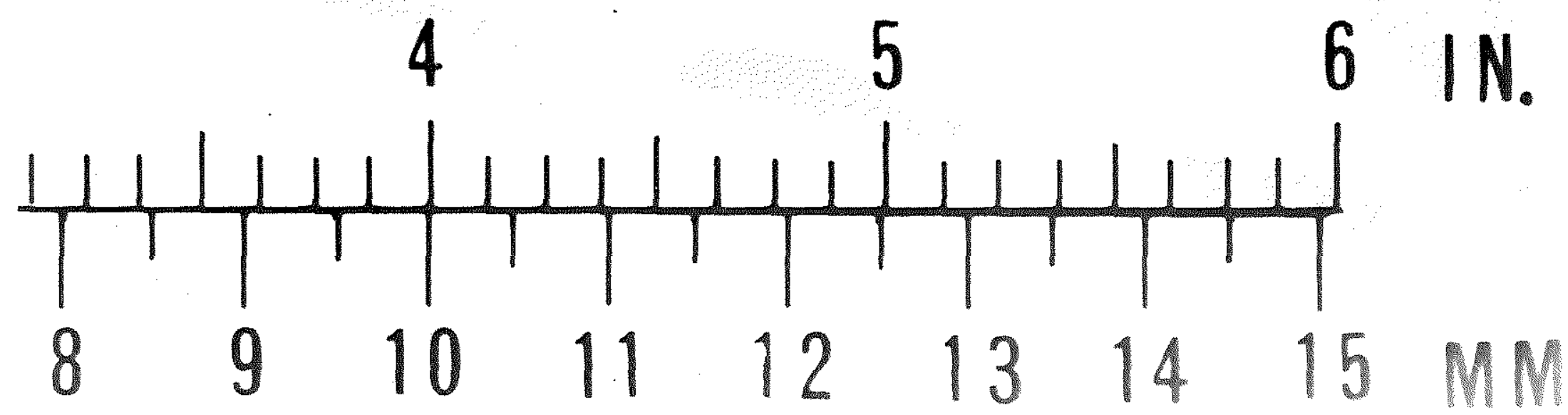

Figure 4-10. Typical Surface Condition Of The Type 316 SS Specimens After Sodium Removal By The Steam/Argon Process 


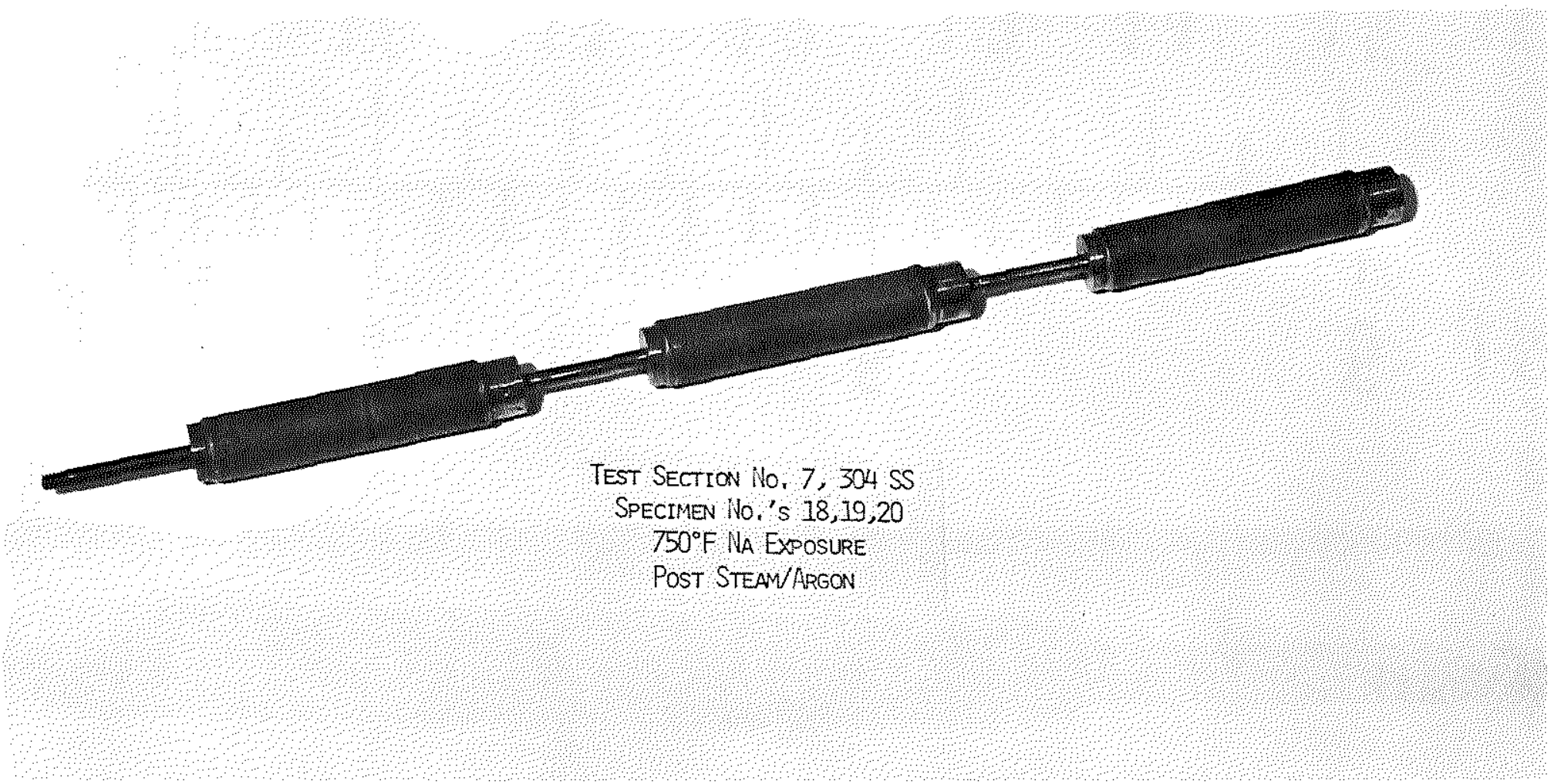

Figure 4-11. Typical Surface Condition Of The Type 304 SS Specimens After Sodium Removal By The Steam/Argon Process 


\subsection{WATER EXPOSURE}

Underwater storage of spent fuel has been used for years. Its advantages militate for its use unless peculiar safety and/or materials compatibility problems exist. The effect of water, under certain conditions, on the integrity of fuel element cladding can be severe, depending on its chemistry. Problems such as pitting, intergranular attack, and stress corrosion cracking of austenitic stainless steels in aqueous solutions have been reported and investigated. ${ }^{(4)}$ However, information concerning the corrosion behavior of sodium-exposed stainless steels in aqueous environment is extremely limited. (5) The main purpose of the present study was to provide information regarding the resistance of the LMFBR sodium-exposed fue 1 cladding material to chloride-containing caustic solutions. Based on the results obtained from the present study, recommendations were made regarding the feasibility of water storage for the LMFBR spent fuels in Section 7 .

\subsection{Test Conditions}

Test specimens, sodium removed by the various methods described in the previous section, were water exposed for periods up to three (3) months according to the test matrix given in Table 2-3. As shown in Table 2-4, the specimens were subjected to water exposure under four basic water chemistries:

(1) The first water bath chemistry was prototypic of the water storage pit for PWR spent fuels except without 2000-4000 ppm boron content. This water chemistry and other requirements are given in Table 2-4. 
(2) The second water bath chemistry was similar to that of the PWR water storage pit conditions as shown in Table 2-4. However, in this case the pH level was kept at a constant level of $10+1$.

(3) The third water bath chemistry was identical to that of bath \#1 except with high chloride concentration as shown in Table 2-4.

(4) The fourth water bath chemistry was identical to that of bath \#2 except with high chloride concentration as shown in Table 2-4.

\subsection{Test Procedure and Operation}

As determined by their sodium removal history defined in the test matrix, specimens were assigned to particular positions on the gas manifolds of the four water baths. The threaded end of each specimen was cut off and a $1 / 8^{\prime \prime}$ stainless steel Swagelok union was attached to the remaining $1 / 8^{\prime \prime}$ diameter stub on the specimen before it was attached to a manifold. Each manifold was then attached to regulated argon gas supply with the specimens being immersed in a given water bath. All specimen handling and positioning were conducted while wearing lintless gloves to prevent possible contamination. The schematic diagram of the water exposure system is shown in Figure $5-1$.

Before commencing the water exposure, specimen positions in a given water bath were recorded in the log book and the assemblies subsequently pressurized to $350 \mathrm{psi}$ with the argon supply. This pressure was derived on the assumption that one third (1/3) of the residual pressure (1000 psi) due to fission gas released at the end of the life of the fuel rods would still be retained. Any pressure drop, as indicated on the pressure gauges, enabled the detection of leakage. After a period of observation for possible leakage, specimens were allowed to complete their intended water exposure at $82^{\circ} \mathrm{C}$.

During the early stage of water bath operation, it was observed that as a 
result of continuing absorption of atmospheric $\mathrm{CO}_{2}$ and additions of $\mathrm{NaOH}$, the high pH baths became buffered and essentially corresponded to a solution of sodium carbonate. As a result, the $\mathrm{pH}$ level of these two baths was confined to the range of 9.7 to 10.5. A similar range in $\mathrm{pH}$ level was also reached in a trial bath which contained $95 \mathrm{mg} \mathrm{CO}{ }_{3}{ }^{\circ} / \mathrm{ml}$ as $\mathrm{Na}_{2} \mathrm{CO}_{3}$ after ten weeks operation. Consequently, the two alkaline baths reached a steady state with respect to their pH level through absorption of atmospheric carbon dioxide.

During the routine operation of the water baths, the chloride content of the water baths were analyzed approximately twice a week. For high level chlorides, a titrimetric specific ion probe was employed. The standard titration curves have less than $5 \%$ Relative Standard Deviation (RSD). For low chlorides, from less than 50 to 0.05 microgram range, turbidimetric spectrophotometry was employed for analysis. The standard calibration curves again have less than 5\% RSD. Duplicate samples were taken, and replicate analyses were performed on the same samples.

Visual examination of the specimens was conducted daily throughout the water exposure period while the specimen pressure was monitored constantiy to detect any specimen failure. After the specimens completed their intended exposure as defined in Table 2-3, they were withdrawn from the water baths. Some of these specimens were subjected to destructive posttest specimen characterization while the rest of the specimens were reinserted into the water bath to accumulate additional water exposure.

\subsection{Test Resuits}

As defined in the test matrix (Table 2-3), a total of sixty (60) specimens were tested in the present investigation. The test results obtained from the water exposure are summarized in Tables 5-1 to 5-4 for the corroded Type 316 stainless steel specimens and the deposit-bearing Type 304 stainless steel specimens, respectively. 


\subsubsection{Corroded Type 316 Stainless Steel Specimens}

The water exposure results of the corroded Type 316 stainless steel specimens along with their sodium exposure and sodium removal histories are given in Table 5-1. Since the main purpose of the present investigation was a screening test, a simple "fail or pass" criterion was adopted for test evaluation. As shown in Table 5-1, all specimens completed their intended exposure without failure. After visual examination, selected specimens were destructively examined while the rest of the specimens were reinserted into the water baths for additional exposure. This information is given in the last column of Table 5-2 for a given specimen.

It is important to note that specimen \#14 failed at the upper weld during re-pressurization at the start of additional water exposure. Subsequent metallographic examination gave no indication of material deterioration, and the failure was apparently caused by a simple weld defect.

\subsubsection{Deposit-Bearing Type 304 Stainless Steel Specimens}

Results on water corrosion of the deposit-bearing Type 304 stainless steel specimens and their sodium exposure and sodium removal histories are given in Tables 5-3 and 5-4. As shown in Table 5-3, a total of seven (7) specimens failed before completing their intended water exposure while localized rusting occurred in most of the unfailed specimens. The sodium exposure temperature of these specimens varies with their positions in the economizer (1 iquid metal heat exchanger) from which they were manufactured. In Table 5-4, the specimens listed in order of increasing sodium exposure temperature (rather than specimen number) reveal an important trend that all failures involved specimens exposed to sodium at temperatures above $499^{\circ} \mathrm{C}$. Furthermore, six (6) out of the seven (7) failures occurred in water bath \#3 (high chloride and neutral solution), as noted in the last two columns of the table. This indicates that a high $\mathrm{pH}$ environment (bath \#4) is beneficial for the test material because it tends to inhibit and/or retard the corrosion mechanism. In addition, it is also important to note that the failures observed in bath \#3 involved specimens with sodium removed by all three sodium cleaning processes. 


\subsubsection{Additional Testing}

Although there has been no failure in the Type 316 stainless steel specimens in any one of the four water baths for periods up to three (3) months as defined in the test matrix, certain specimens were selected for extended exposure, in order to obtain long term behavior of this material under the present test conditions. This information will enhance and substantiate the conclusions derived from the present screening investigation. In Table 5-2, the results on specimens subjected to the extended water exposure are briefly described. It is noted that as of this writing, no specimen failure occurred for periods up to five (5) months.

In view of the failures observed on the deposit-bearing Type 304 stainless stee 1 specimens, additional tests were conducted to determine the effect of sensitization and the sodium mass transfer deposits on the corrosion behavior of the test materials. Specimens in the annealed, as-received, and sodium-exposed (but with a11 mass transfer deposits removed by surface polishing) conditions were exposed in bath \#3 (high chloride and neutral solution) for periods up to one month. In addition, a sensitized specimen was also tested without internal pressurization to study the effect of internal stress on the failures observed in the present investigation. The results shown in Table 5-4 indicate that for periods up to one month there was no obvious deterioration or failure among those specimens. Consequently, factors such as cold work, sensitization, and internal pressurization were not the direct cause of the failures observed in the present investigation. Detailed analyses on the possible failure mechanism are discussed in the next section: 
Table 5-1

Corroded Type 316 SS Specimens Exposed in Water Baths

\begin{tabular}{|c|c|c|c|c|c|}
\hline \multirow{2}{*}{$\begin{array}{l}\text { Na Removat } \\
\text { Methods }\end{array}$} & \multirow{2}{*}{$\begin{array}{c}\text { Test Period } \\
\text { (Month) }\end{array}$} & \multicolumn{4}{|c|}{ Water Bath (a) } \\
\hline & & $\# 1$ & $\# 2$ & $\# 3$ & $\# 4$ \\
\hline \multirow{3}{*}{ Alcohol } & 1 & & & & \\
\hline & 2 & & & & \\
\hline & 3 & 1 & 9 & 8 & 23 \\
\hline \multirow{3}{*}{$\begin{array}{l}\text { Water Vapor- } \\
\text { Argon (WVA) }\end{array}$} & 1 & & 13 & 11 & 10 \\
\hline & 2 & & 15 & 12 & 14 \\
\hline & 3 & 24,26 & 25,29 & 28,30 & 27 \\
\hline \multirow{3}{*}{$\begin{array}{c}\text { Steam-Argon } \\
(\text { KNK) }\end{array}$} & 1 & & 2 & 4 & 6 \\
\hline & 2 & & 3 & 5 & 7 \\
\hline & 3 & 21,22 & 16,17 & 19,20 & 18 \\
\hline
\end{tabular}

(a) The number shown in each water bath are specimen numbers. All specimens have completed their intended exposure without incident. Information concerning specimen history and test results is given in Table 5-2. 
Table 5-2

Status of Water Exposure - Corroded Type 316 SS

\begin{tabular}{|c|c|c|c|c|c|c|}
\hline \multirow{2}{*}{$\begin{array}{l}\text { SPECIMEN } \\
\text { NO. }\end{array}$} & \multirow{2}{*}{$\begin{array}{l}\text { Na REMOVAL } \\
\text { PROCESS }\end{array}$} & \multicolumn{2}{|c|}{$\begin{array}{c}\text { ORIGINAL TEST } \\
\text { MATRIX EXPOSURE }\end{array}$} & \multicolumn{2}{|c|}{$\begin{array}{l}\text { ADDITIONAL } \\
\text { EXPOSURE }\end{array}$} & \multirow{2}{*}{$\begin{array}{c}\text { TOTAL } \\
\text { EXPOSURE } \\
(h r .)\end{array}$} \\
\hline & & BATH \# & TIME $\left(h r_{.}\right)$ & BATH \# & TIME (hr.) & \\
\hline $\begin{array}{l}1 \\
2 \\
3 \\
4 \\
5 \\
6 \\
7 \\
8 \\
9 \\
10 \\
11 \\
12 \\
13 \\
14 * \\
15 \\
16 \\
17 \\
18 \\
19 \\
20 \\
21 \\
22 \\
23 \\
24 \\
25 \\
26 \\
27 \\
28 \\
29 \\
30\end{array}$ & $\begin{array}{l}\text { Alcohol } \\
\text { KNK } \\
\text { KNK } \\
\text { KNK } \\
\text { KNK } \\
\text { KNK } \\
\text { KNK } \\
\text { Alcohol } \\
\text { Alcohol } \\
\text { WVA } \\
\text { WVA } \\
\text { WVA } \\
\text { WVA } \\
\text { WVA } \\
\text { WVA } \\
\text { KNK } \\
\text { KNK } \\
\text { KNK } \\
\text { KNK } \\
\text { KNK } \\
\text { KNK } \\
\text { KNK } \\
\text { Alcohol } \\
\text { WVA } \\
\text { WVA } \\
\text { WVA } \\
\text { WVA } \\
\text { WVA } \\
\text { WVA } \\
\text { WVA }\end{array}$ & $\begin{array}{l}1 \\
2 \\
2 \\
3 \\
3 \\
4 \\
4 \\
3 \\
2 \\
4 \\
3 \\
3 \\
2 \\
4 \\
2 \\
2 \\
2 \\
4 \\
3 \\
3 \\
1 \\
1 \\
4 \\
1 \\
2 \\
1 \\
4 \\
3 \\
2 \\
3\end{array}$ & $\begin{array}{r}2160 \\
742 \\
1440 \\
742 \\
1404 \\
742 \\
1440 \\
2160 \\
2160 \\
722 \\
727 \\
1440 \\
729 \\
1440 \\
2160 \\
2160 \\
2160 \\
2170 \\
2208 \\
2208 \\
2163 \\
2163 \\
2160 \\
2178 \\
2160 \\
2178 \\
2160 \\
2173 \\
2160 \\
2173\end{array}$ & $\begin{array}{l}- \\
2 \\
- \\
3 \\
- \\
4 \\
- \\
- \\
- \\
- \\
- \\
- \\
- \\
- \\
2 \\
3 \\
4 \\
3 \\
3 \\
1 \\
3 \\
- \\
1 \\
2 \\
3 \\
4 \\
- \\
3 \\
3\end{array}$ & 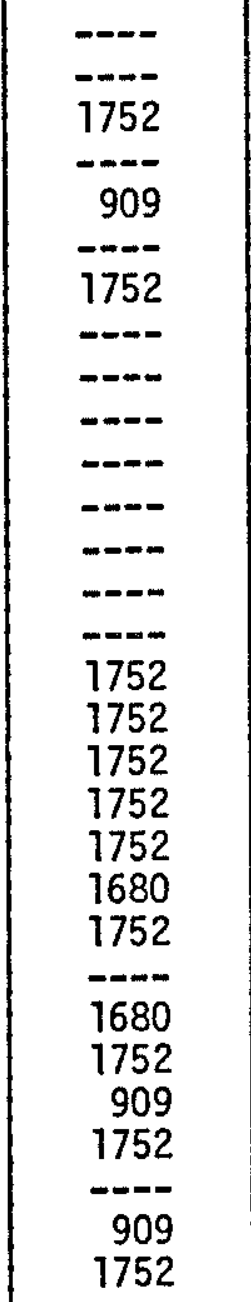 & $\begin{array}{r}2160 \\
742 \\
3192 \\
742 \\
2349 \\
742 \\
3192 \\
2160 \\
2160 \\
722 \\
721 \\
1440 \\
729 \\
1440 \\
2160 \\
3912 \\
3912 \\
3922 \\
3960 \\
3960 \\
3843 \\
3915 \\
2160 \\
3858 \\
3912 \\
3087 \\
3912 \\
2173 \\
3069 \\
3925\end{array}$ \\
\hline
\end{tabular}

Failed at upper weld at start of additional water exposure. 
Table 5-3

Deposit-Bearing Type 304 SS Specimens Exposed in Water Baths

\begin{tabular}{|c|c|c|c|c|c|}
\hline \multirow{2}{*}{$\begin{array}{l}\text { Na Removal } \\
\text { Methods }\end{array}$} & \multirow{2}{*}{$\begin{array}{l}\text { Test Period } \\
\text { (Month) }\end{array}$} & \multicolumn{4}{|c|}{ Water Bath $(a)$} \\
\hline & & $\# 1$ & $\# 2$ & $\# 3$ & $\# 4$ \\
\hline \multirow{3}{*}{ Al cohol } & 1 & & & & \\
\hline & 2 & & & & \\
\hline & 3 & 11 & 9 & $12^{f}$ & 10 \\
\hline \multirow{3}{*}{$\begin{array}{l}\text { Water Vapor- } \\
\text { Argon (WVA) }\end{array}$} & 1 & & 8 & $2^{f-}$ & 5 \\
\hline & 2 & 3,15 & 7 & $1^{f}$ & 6 \\
\hline & 3 & 3,15 & 4,16 & $14^{f}, 17^{f}$ & 13 \\
\hline \multirow{3}{*}{$\begin{array}{c}\text { Steam-Argon } \\
\text { (KNK) }\end{array}$} & 1 & & 23 & 20 & $18^{f}$ \\
\hline & 2 & & 24 & 22 & 19 \\
\hline & 3 & 21,26 & 25,29 & $28,30^{f}$ & 27 \\
\hline
\end{tabular}

(a) The number shown in each water bath are specimen numbers. The Superscript " $f$ " indicates that the specimen had failed before reaching its intended exposure. Information concerning specimen history and water exposure results are given in Table $5-4$ 
Table $5-4$

Status of Hater Exposure - Deposit-Bearing Type 304 SS

\begin{tabular}{|c|c|c|c|}
\hline $\begin{array}{l}\text { SPECIMEN } \\
\text { NO. }\end{array}$ & $\begin{array}{c}\mathrm{Na} \\
\text { REMOVAL } \\
\text { PROCESS }\end{array}$ & $\begin{array}{l}\text { BATH } \\
\text { NO. }\end{array}$ & $\begin{array}{c}\text { TOTAL } \\
\text { EXPOSURE } \\
(\mathrm{hr} .)\end{array}$ \\
\hline $\begin{array}{l}1 \\
2 \\
3 \\
4 \\
5 \\
6 \\
7 \\
8 \\
9 \\
10 \\
11 \\
12 \\
13 \\
14 \\
15 \\
16 \\
17 \\
18 \\
19 \\
20 \\
21 \\
22 \\
23 \\
24 \\
25 \\
26 \\
27 \\
28 \\
29 \\
29 a \\
30\end{array}$ & 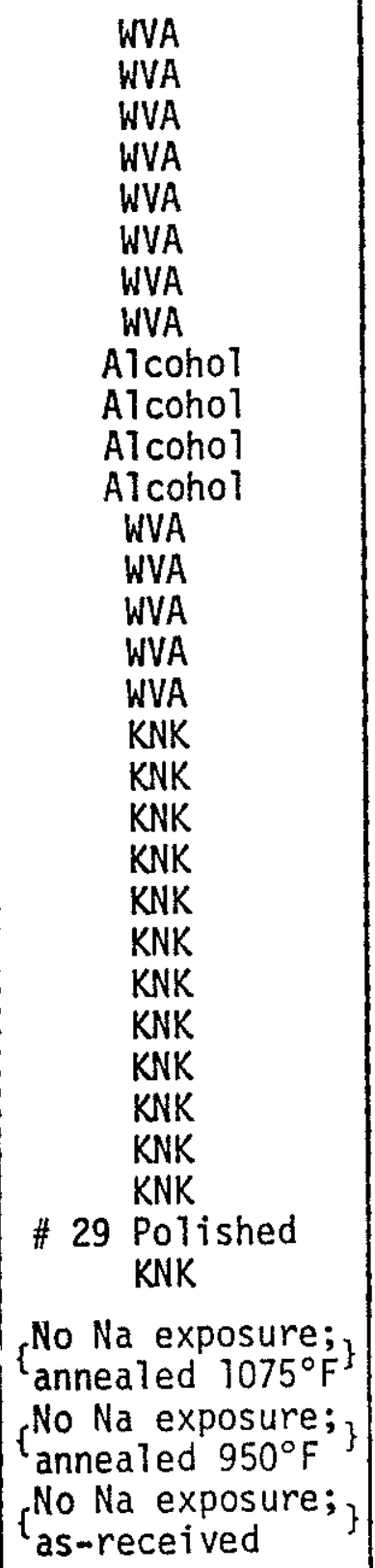 & $\begin{array}{l}3 \\
3 \\
1 \\
2 \\
4 \\
4 \\
4 \\
2 \\
2 \\
2 \\
4 \\
4 \\
1 \\
3 \\
4 \\
3 \\
3\end{array}$ & $\begin{array}{c}72^{\star} \\
216^{\star} \\
2160 \\
2160 \\
721 \\
1467 \\
1488 \\
720 \\
2160 \\
2160 \\
2160 \\
120^{*} \\
2188 \\
65^{\star} \\
2177 \\
2177 \\
233^{\star} \\
336^{\star} \\
1440 \\
721 \\
2188 \\
1444 \\
721 \\
1444 \\
2177 \\
2188 \\
2180 \\
2173 \\
2160 \\
840 \\
92^{\star} \\
1152 \\
840 \\
840\end{array}$ \\
\hline
\end{tabular}

* Specimen failed. 


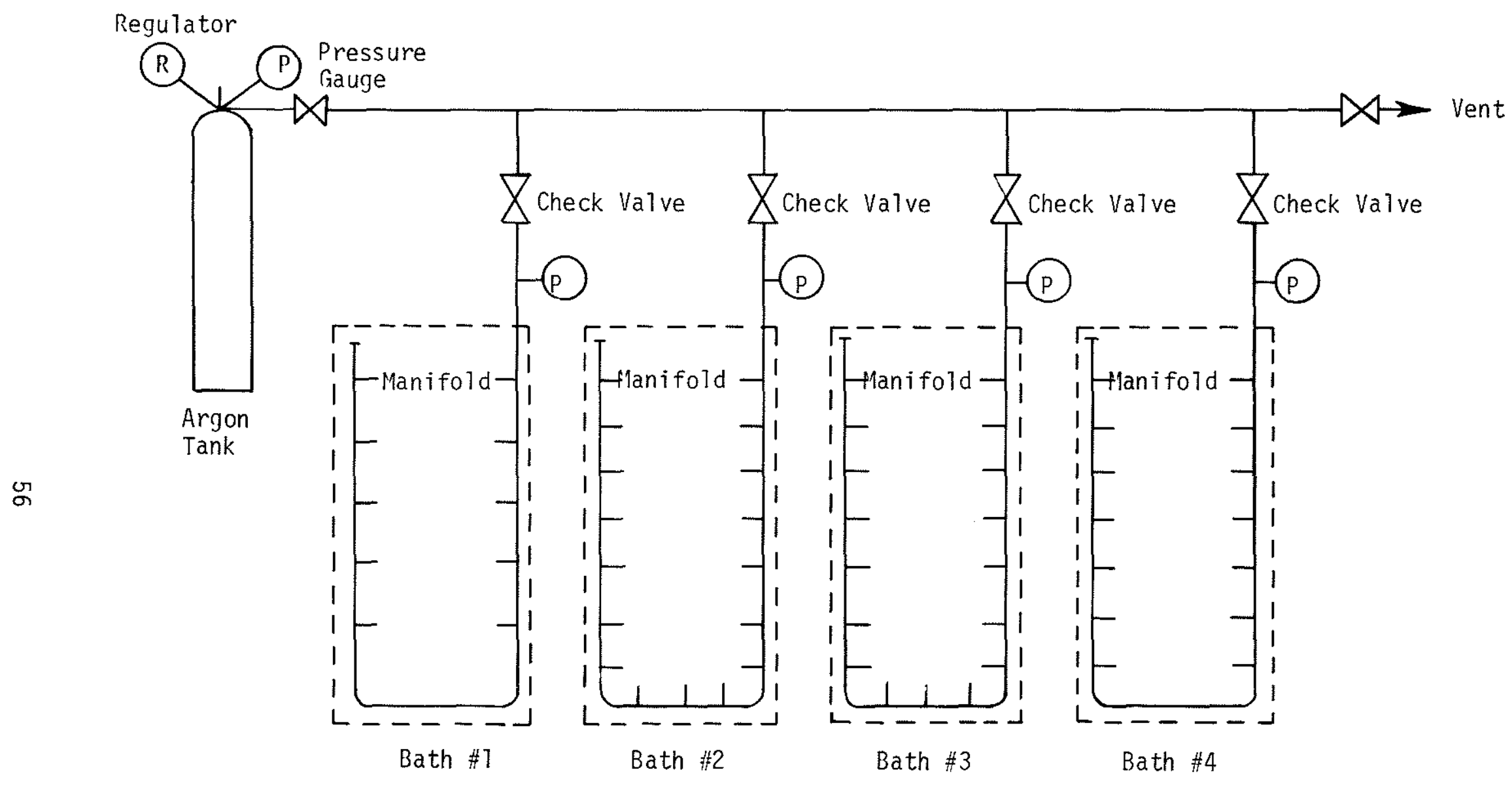

Figure 5-1 Schematic Diagram of Water Exposure System 


\subsection{POST-TEST SPECIMEN CHARACTERIZATION}

In addition to visual examination, optical and electron microscopy and electron microprobe analyses were employed to characterize the posttest specimens. The purpose was to assess the metallurgical and structural effects on the corrosion resistance of the corroded Type 316 stainless steel, and the deterioration and failure observed on the deposit-bearing Type 304 stainless steel.

The grain size and anisotropy of the test materials in the as-received and post-test conditions were examined by optical microscopy. Surface morphology and the substructures of these materials were also examined by electron microscopy. In addition, electron microprobe analys is was conducted to establish the alloy depletion and element distribution on the specimen surface.

\subsection{Corroded Type 316 Stainless Steel}

The corroded Type 316 stainless steel specimens were made of $20 \%$ coldworked Type 316 stainless steel tubing (prototypic LMFBR cladding alloy) with two different sodium exposure histories. The microstructure of specimens made of the $649^{\circ} \mathrm{C}\left(1200^{\circ} \mathrm{F}\right)$ sodium-exposed (5300 hours) cladding material is shown in Figure 3-3. Massive intragranular carbide precipitation along the slip lines resulting from severe cold-work is evident in Figure 3-4(a). The cold-work effect apparently reduced significantly the susceptibility of the material to sensitization. In Figure 3-4(b), the presence of a ferrite layer of approximately $8 \mu \mathrm{m}$ thick, and the Mo$\mathrm{Cr}$ intermetallic compound at the alloy/sodium interface is evident. Formation of these phases in the austenitic alloy surface is mainly due to the preferential depletion of nickel (austenite stabilizer) resulting from high temperature sodium exposure. 
The microstructure of specimens of the $718^{\circ} \mathrm{C}\left(1325^{\circ} \mathrm{F}\right)$ sodium-exposed ( 5300 hours) cladding alloy is shown in Figure 3-5 (a). In contrast to the $649^{\circ} \mathrm{C}$ sodium exposed structure, a large amount of sigma phase but less extensive carbide precipitation was observed in the $718^{\circ} \mathrm{C}$ sodium exposed structure. The significant reduction in intragranular carbides is due mainly to the rapid growth of ferrite in the austenite matrix during the early exposure at $718^{\circ} \mathrm{C}$.

However, the ferrite phase in the Type 316 SS matrix is known to be unstable after about 2000 hours, and begins to decompose due to the formation of sigma phase. Consequently, it is no surprise that large amounts of sigma phase are present in this alloy after 5300 hours sodium exposure at $718^{\circ} \mathrm{C}$. It is also important to note that a thicker ferrite layer $(25 \mu \mathrm{m})$ was formed in this case compared to a ferrite layer of about $8 \mu \mathrm{m}$ formed in the $649^{\circ} \mathrm{C}$ sodium-exposed material. Microstructure of the same material after sodium removal by the steam/ argon (KNK) process is shown in Figure 3-5 (b). No significant change was observed in the alloy matrix, however, the intermetallic phase at the specimen surface appeared to be selectively dissolved during the sodium removal process.

Electron microprobe analys is was conducted on a $649^{\circ} \mathrm{C}$ sodium-exposed Type 316 SS specimen. The results by line tracing, shown in Figure 6-7, indicate that the precipitates formed at the alloy/sodium interface are mainly Cr-Mo intermetallic phases.

Scanning Electron Microscope (SEM) photomicrographs shown in Figure 6-2 reveal the surface morphology of the corroded Type 316 SS specimens $\left(5300\right.$ hours at $\left.718^{\circ} \mathrm{C}\right)$. No significant change in surface condition was observed resulting from the water vapor/argon cleaning process as shown in Figure 6-2(a). However, due to the higher operating temperature involved in the steam/argon process, obvious change in surface morphology can be noted in Figure 6-2(b). In Figure 6-3, the SEM surface morphology 
and element distribution obtained by Electron Dispersive Analyses of $X$-rays (EDAX) are shown for a Type 316 SS specimen sodium exposed at $649^{\circ} \mathrm{C}$ for 5300 hours. The nodules (site " $A$ " in Figure 6-3a) on the alloy surface resulting from sodium corrosion are rich in both $\mathrm{Cr}$ and Mo. This is consistent with the Electron Microprobe results shown in Figure 6-1. The Fe-rich " $B$ " site shown in the same figure is the "ferrite" layer shown in Figure 3-4.

\subsection{Deposit-Bearing Type 304 Stainless Steel Specimens}

Surface appearances of deposit-bearing Type 304 SS specimens sodium removed by the steam/argon process are shown in Figure 6-4. Specimen No. 26 shows the surface appearance in the as-cleaned condition, while specimen No. 30 shows that as a result of high chloride (nominally 750 $\mathrm{ppm}$ chloride) and neutral water exposure severe corrosion and failure had occurred after three (3) days at the test temperature, $82^{\circ} \mathrm{C}\left(180^{\circ} \mathrm{F}\right)$. It is interesting to note that the volume change due to formation of corrosion products led to the bending observed on specimen No. 30 .

Surface cracking and pin-hole leaks were developed on the deposit bearing Type 304 SS specimens after exposure in the high chloride baths as shown in Figure 6-5. The majority of the failures resulted from exposure in bath \#3 (high chloride and neutral), and only one failure was observed in bath \#4 (high chloride and high $\mathrm{pH}$ ). Therefore, high pH solution apparently enhances the cracking resistance of the test material in high chloride environment.

Typical surface appearance of the failed deposit-bearing Type 304SS specimens are shown in Figures 6-6 and 6-7. Based on these results, it can be concluded that the failure was apparently initiated by severe localized pitting, and the subsequent formation of the transition metal chlorides accelerated the crack propagation through wedging effect by volume expansion. 
Surface morphology of the deposit-bearing Type 304 SS specimens and that of the corroded Type 376 SS specimens were compared by SEM characterization, and the results are shown in Figure 6-8. Semi-adherent interlocking precipiatates were observed on the Type 304 SS surface while "nodules" and "valleys" were observed on the corroded Type 316 SS surface. As in the case of Type $316 \mathrm{SS}$, sodium removal by alcohol and/or water vapor/ argon processes did not affect the surface morphology of the Type 304 SS specimens. However, surface tarnishing, due to caustic reaction occurred during sodium removal by steam/argon process as shown in Figure 6-9 (a). Multiple cracking and severe pitting resulting from high chloride water exposure of the Type 304 SS specimen surfaces are visible in Figure 6-9(b). EDAX analyses were conducted on the specimen surfaces shown in Figure 6-9, and the results are given in Figure 6-10. The surface deposits on the specimen with $454^{\circ} \mathrm{C}$ sodium exposure were mainly iron-rich particles, while those on the specimen with $525^{\circ} \mathrm{C}$ sodium exposure were high chromium-containing precipitates. This is characteristic of the deposition phenomena in a dynamic and non-isothermal sodium/stainless steel system.

The chemical composition of the corrosion products formed on the high chloride water exposed Type 304 SS specimens was further characterized by EDAX. In general, there were three (3) different kinds of reaction products formed on the specimen surface as shown in Figure 6-11(a). The EDAX results shown in Figure 6-11(b) showed that the particle "A" is a chloride without any alloy component of the stainless steel. Since it is possible that a small amount of residual sodium may still remain on the specimen surface even after the sodium removal procedure, and it is also known that absorbed sodium "bleeds" out gradually from water rinsed sodiumexposed stainless steel surfaces, it is very likely that the high-chloride particle "A" shown in Figure 6-11 is a $\mathrm{NaCl}$ particle. However, the EDAX results clearly show that the particle "B" is a mixture of iron and chromium chiorides. The presence of high aluminum in the same figure is believed to be caused by alumina $\left(\mathrm{Al}_{2} \mathrm{O}_{3}\right)$ particles imbeded on the surface during specimen preparation. In Figure 6-12(a), the chemical composition of the particle "B" is compared with that of the Type 304 SS alloy matrix, where Figure 6-12(b) shows a comparison between particle " $\mathrm{C}$ " and the Type 304 SS alloy matrix. 
Classical intergranular cracking of the alloy matrix initiated by severe localized pitting is shown in Figure 6-13(a) for a deposit-bearing Type 304 SS specimen exposed in high chloride water solution. In Figure 6-13 (b), the close view of the pitting and the cracking morphology is shown. 


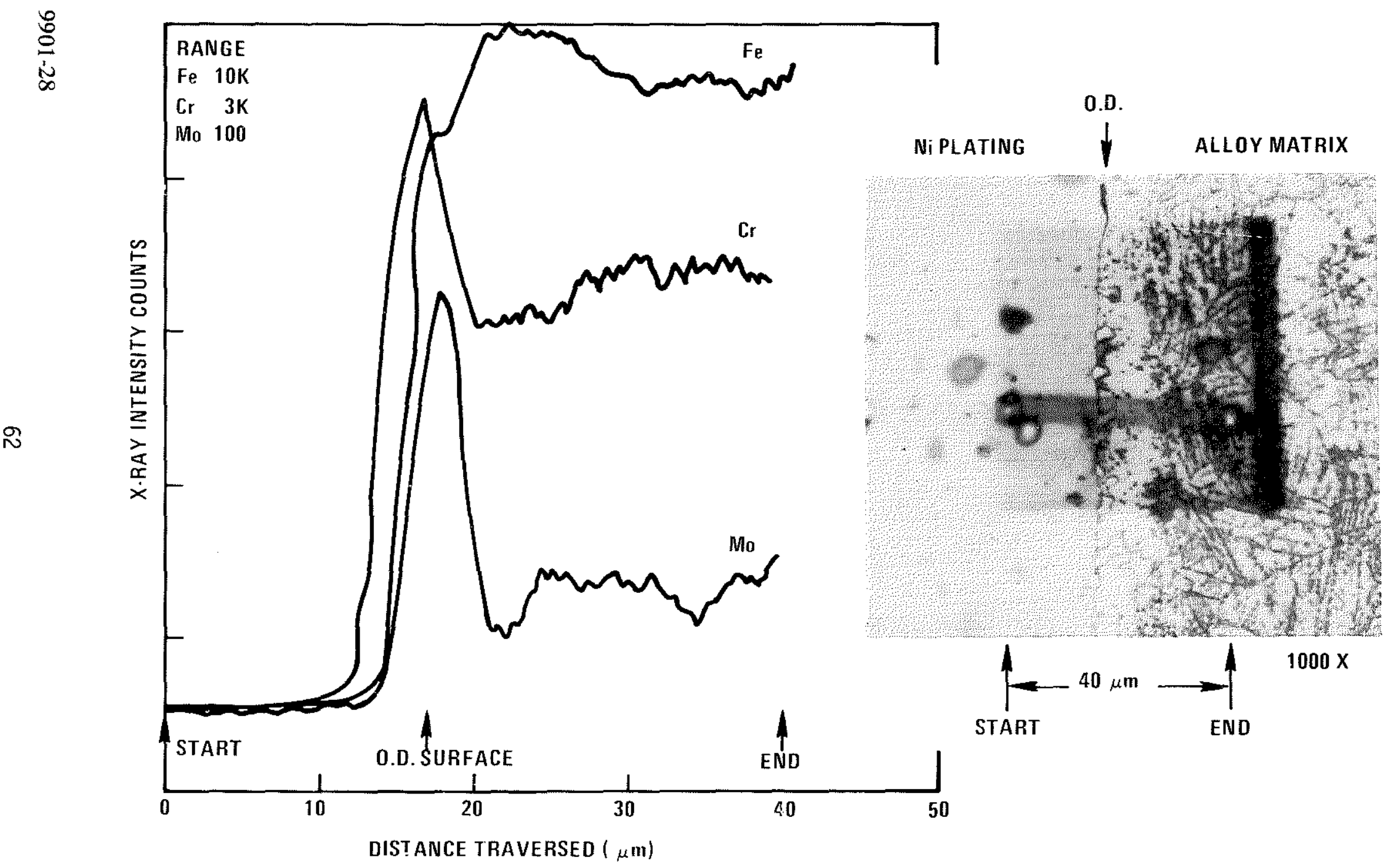

Figure 6-1. Electron Microprobe Analyses Of The Sodium Corroded (5300 Hours At $\left.718^{\circ} \mathrm{C}\right) 20 \%$ Cold-Worked Type $316 \mathrm{SS}$ 


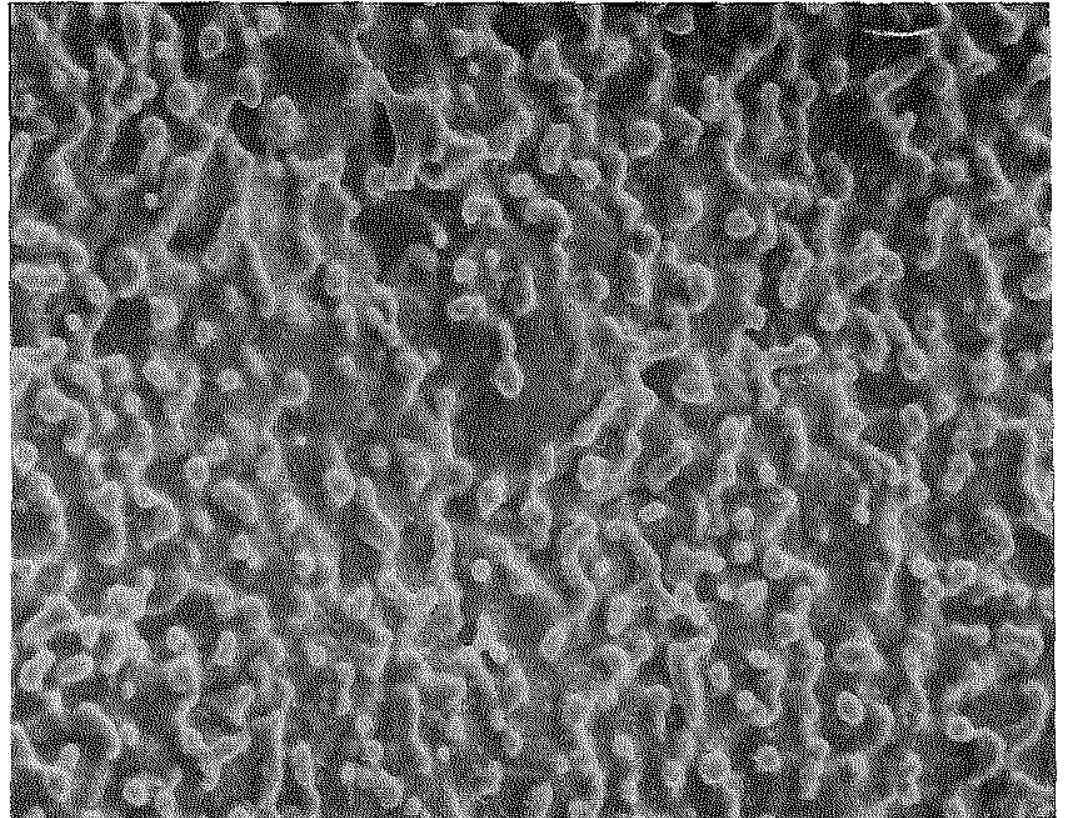

(a)

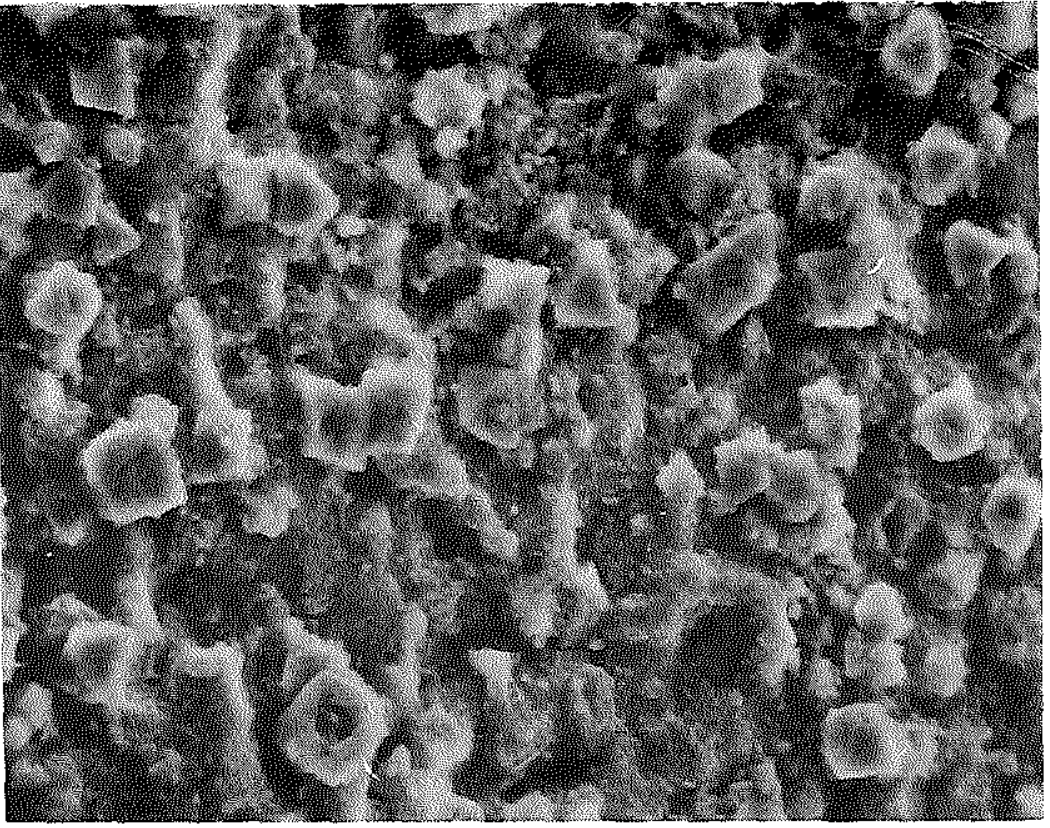

(b)

$10 \mu$

Figure 6-2. SEM Photomicrograph Of Sodium-Exposed (5300 Hours At $718^{\circ} \mathrm{C}$ ) $20 \%$ Cold-Worked Type 316 SS (a) Surface Morphology After Sodium Removal By Water Vapor/Argon Process, 1250 x (b) Surface Morphology After Sodium Removal By Steam/Argon Process, $3000 \mathrm{x}$ 


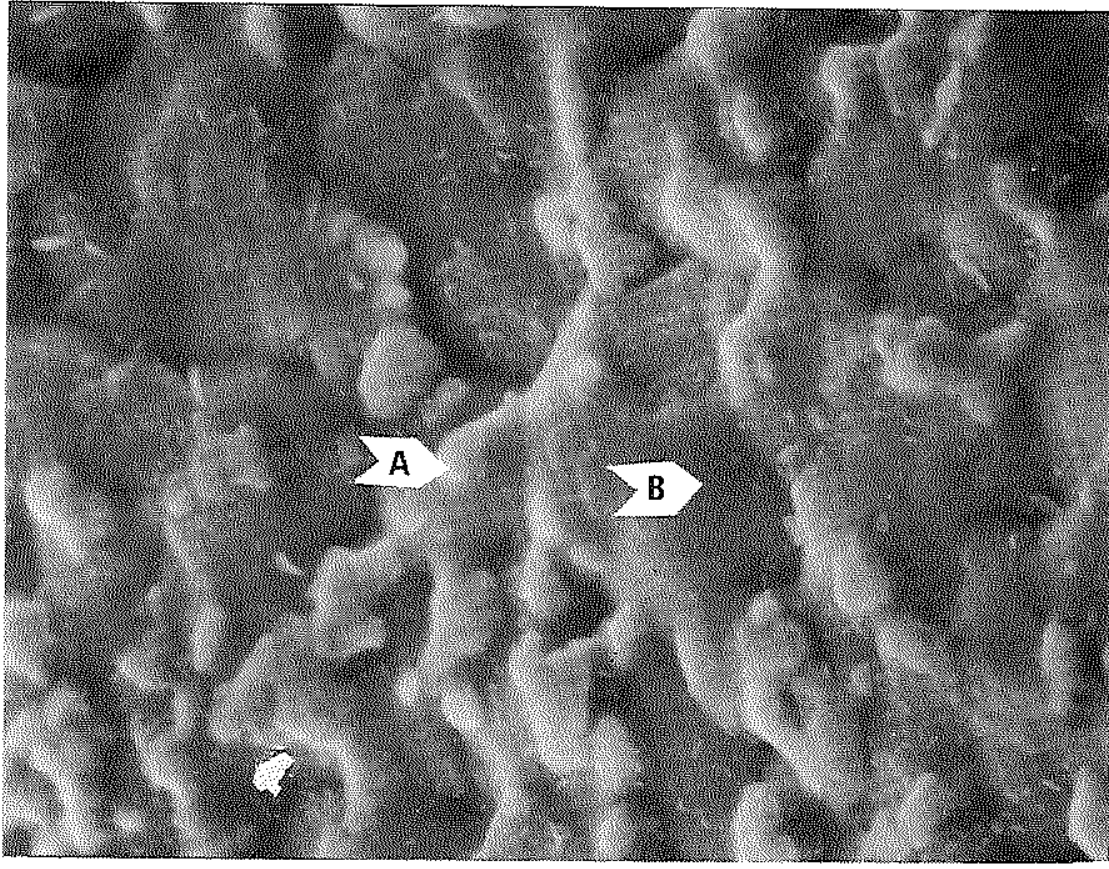

(a)

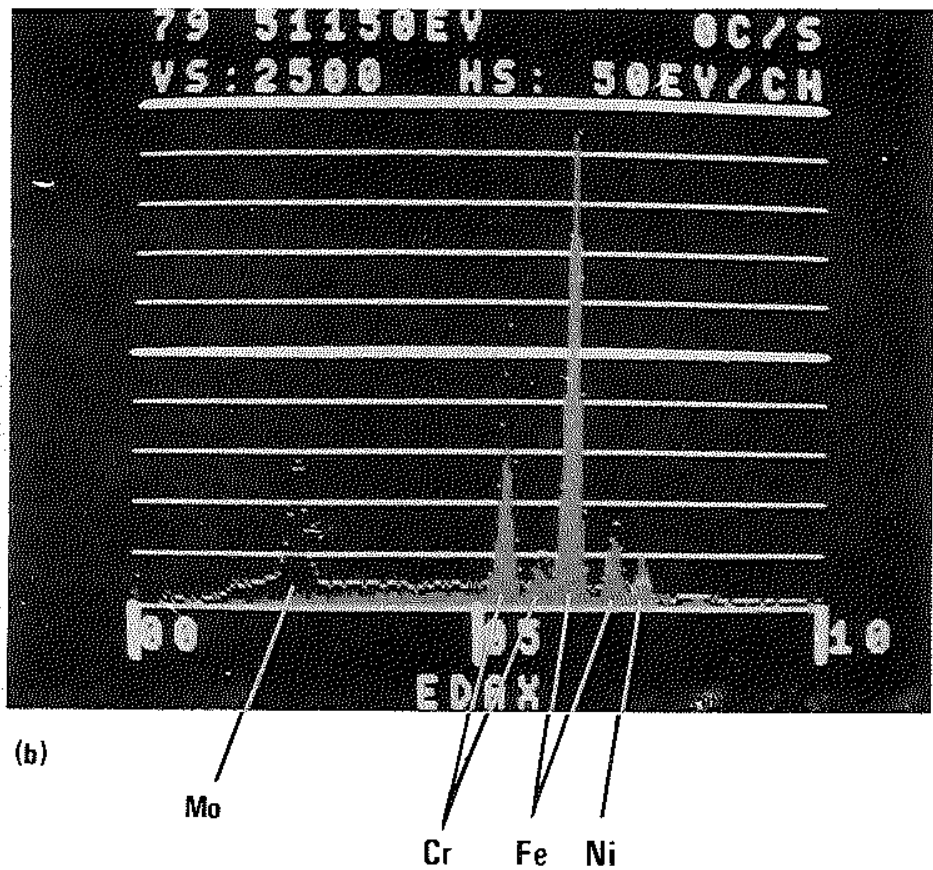

Figure 6-3. Surface Morphology And Element Distribution Of Sodium-Exposed ( 5300 Hours At $\left.649^{\circ} \mathrm{C}\right) 20 \%$ Cold-Worked Type 316 SS (a) SEM Photomicrograph Of Surface Morphology After Sodium Removal By Water/Vapor Argon Process, 4000 x. (b) EDAX Results: Dots Mo And Cr-Rich "A" Site, Bars Fe Rich "B" Site 


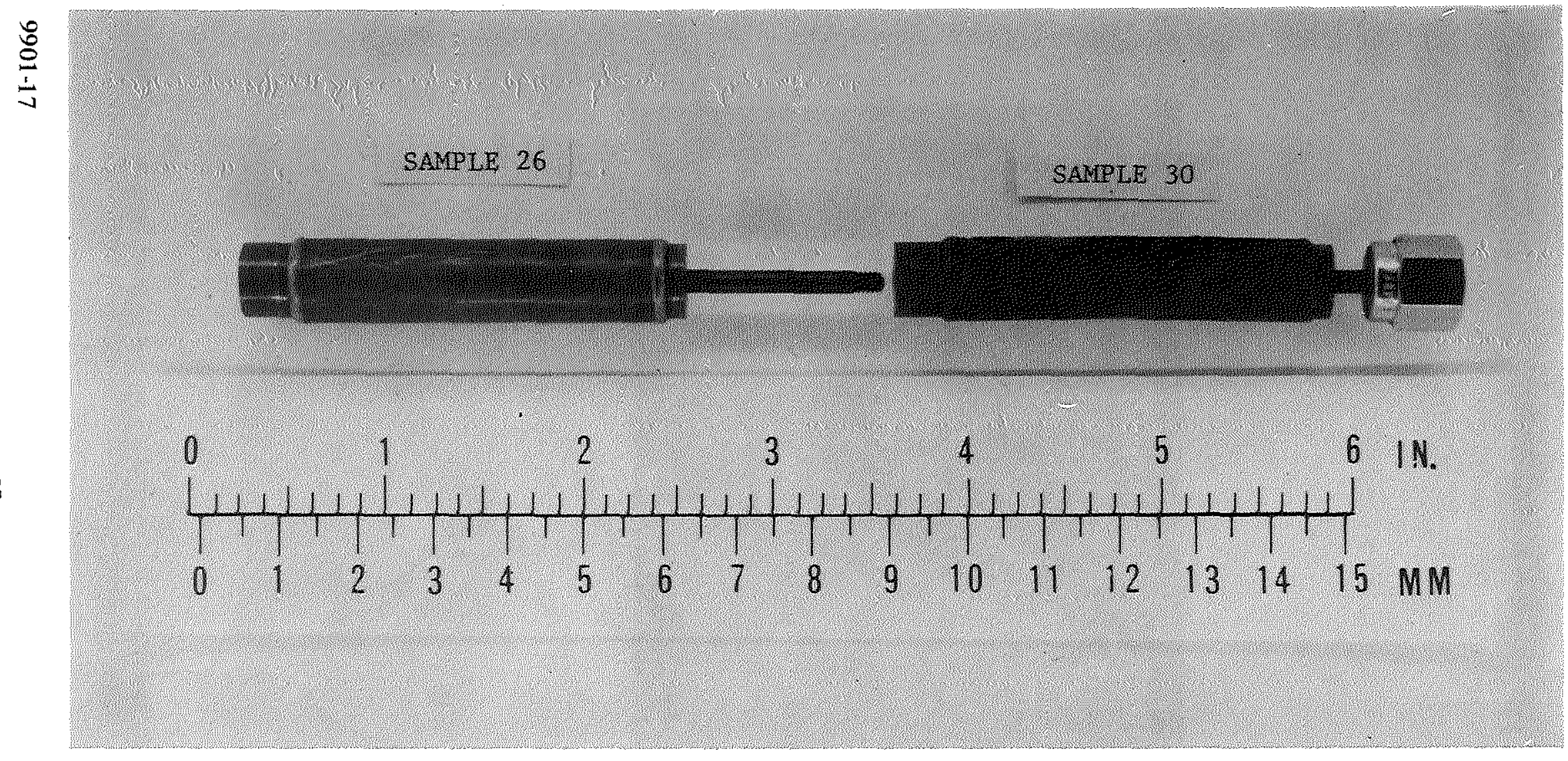

Figure 6-4. Steam/Argon Cleaned Deposit Bearing Type 304 SS Sample $26-3500 \mathrm{hrs}$. in $454^{\circ} \mathrm{C}$ Sodium, As Cleaned Sample $30-3500$ hrs. in $525^{\circ} \mathrm{C}$ Sodium, High Chloride, Neutral Water Exp. 3 Days at $82^{\circ} \mathrm{C}$ 


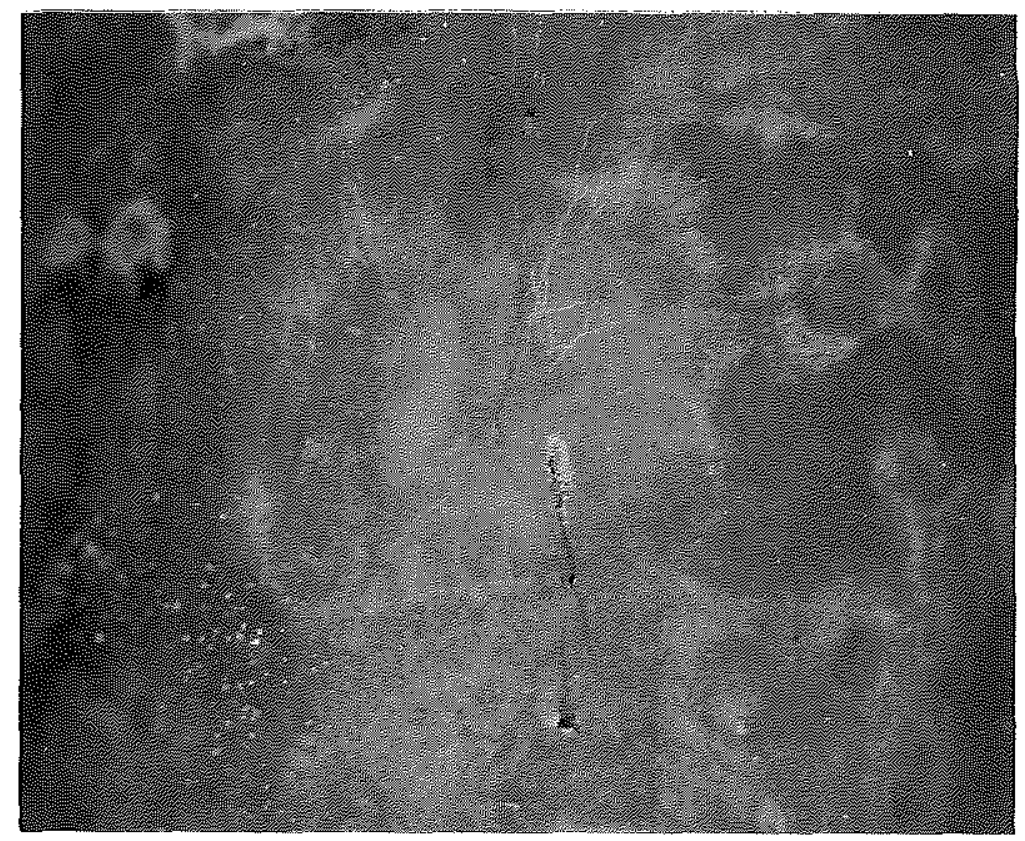

Figure 6-5. Surface Appearance Of Post-Water Exposed Deposit-Bearing Type 304 SS 10x 9901-19 


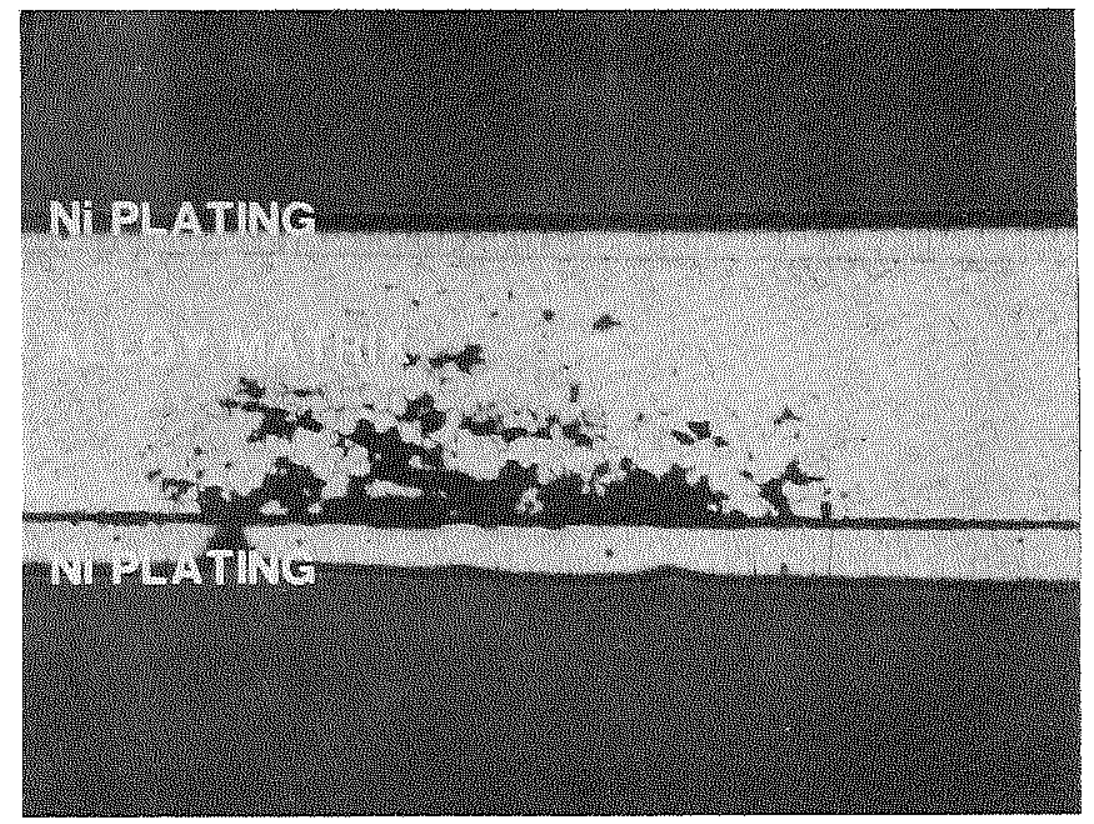

(a)

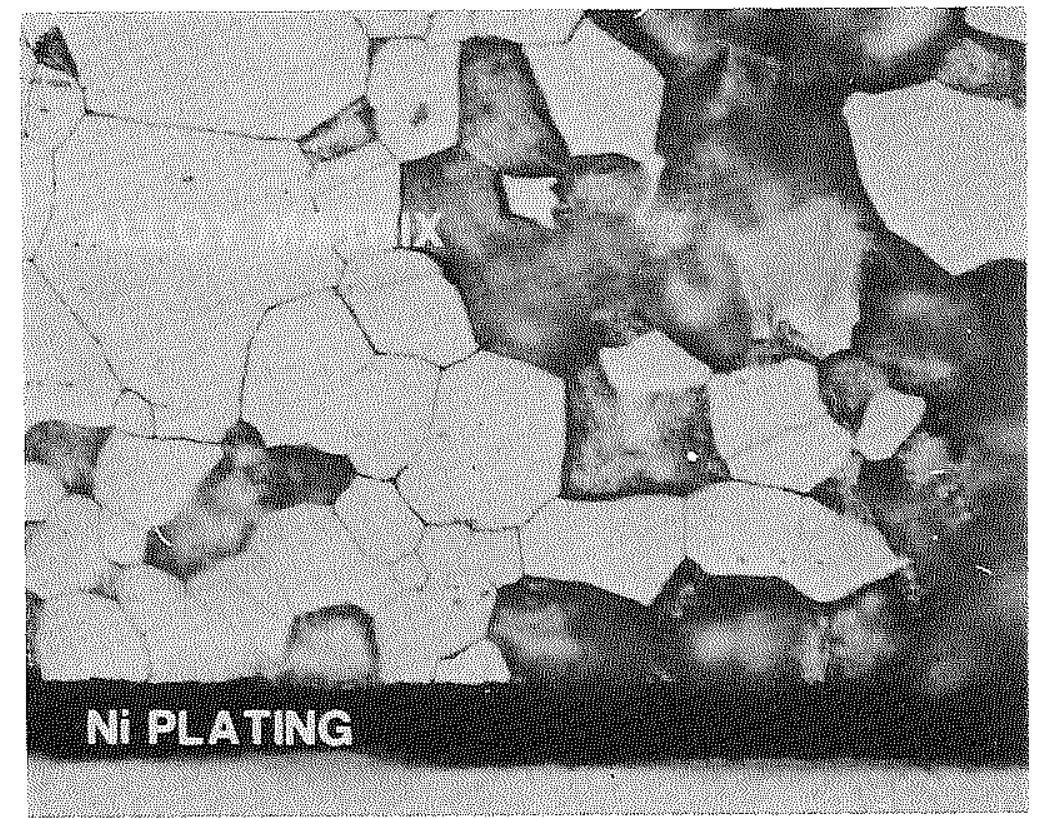

(b)

Figure 6-6. Microstructure Of Deposit-Bearing Type 304 SS After Neutral And High Chloride Water Exposure $\left(82^{\circ} \mathrm{C}\right.$, 10 Days) (a) Severe Localized Pitting, Etch: Gly/HCI/HNO 3,50 x (b) Intergranular Cracking Of The Alloy Matrix, $500 \mathrm{x}$. 


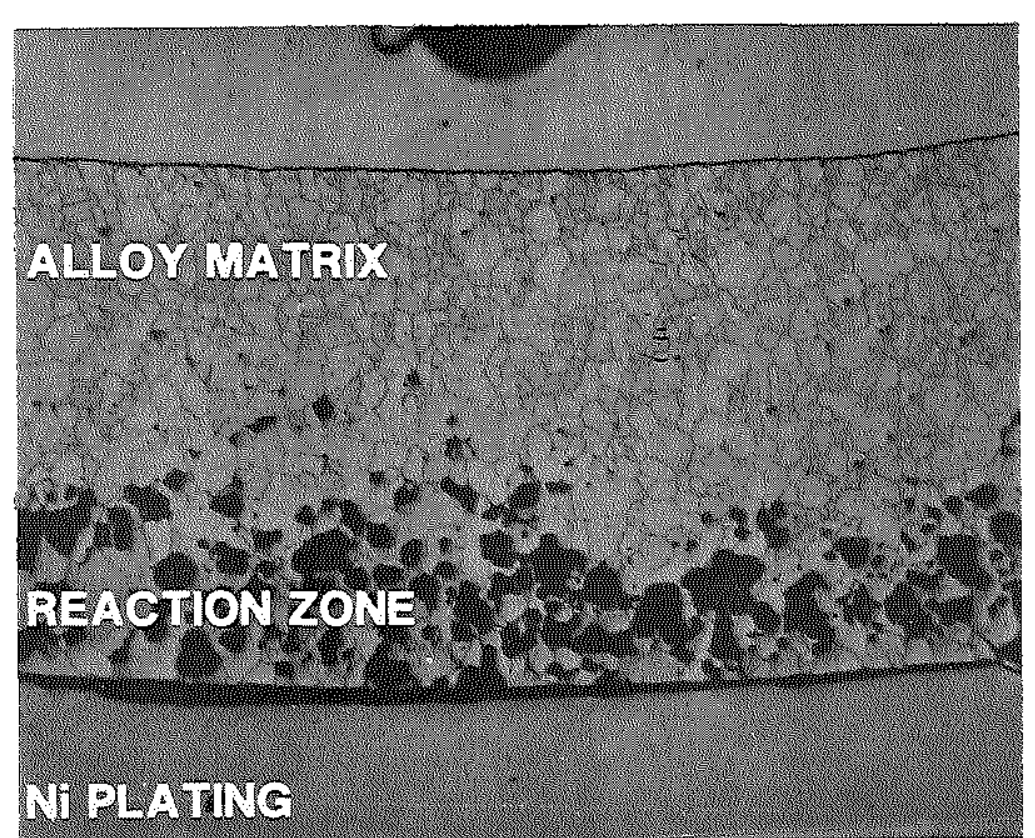

(a)

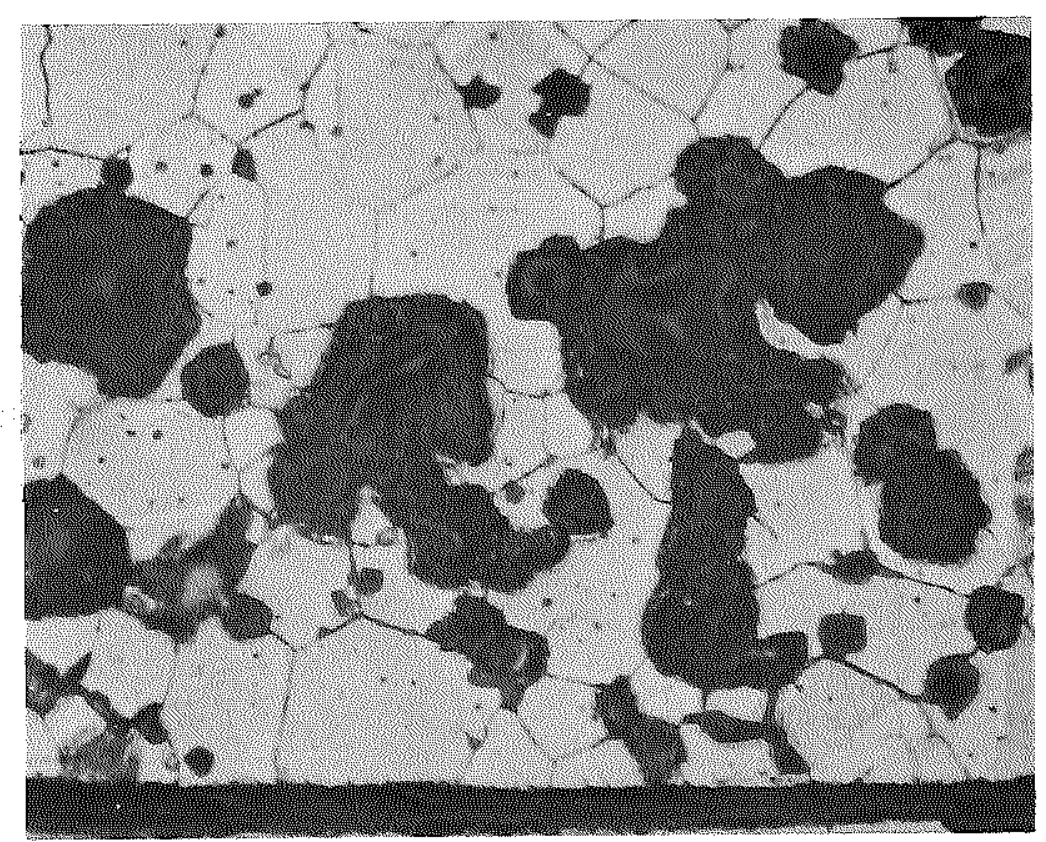

(b)

Figure 6-7. Photomicrograph Of Post-Water Exposed Deposit-Bearing Type 304 SS, Gly/HC1/HNO 3 (a) 100 x, Grain Size-ASTM No. 7, (b) Intergranular Cracking, $500 \mathrm{x}$ 
¿

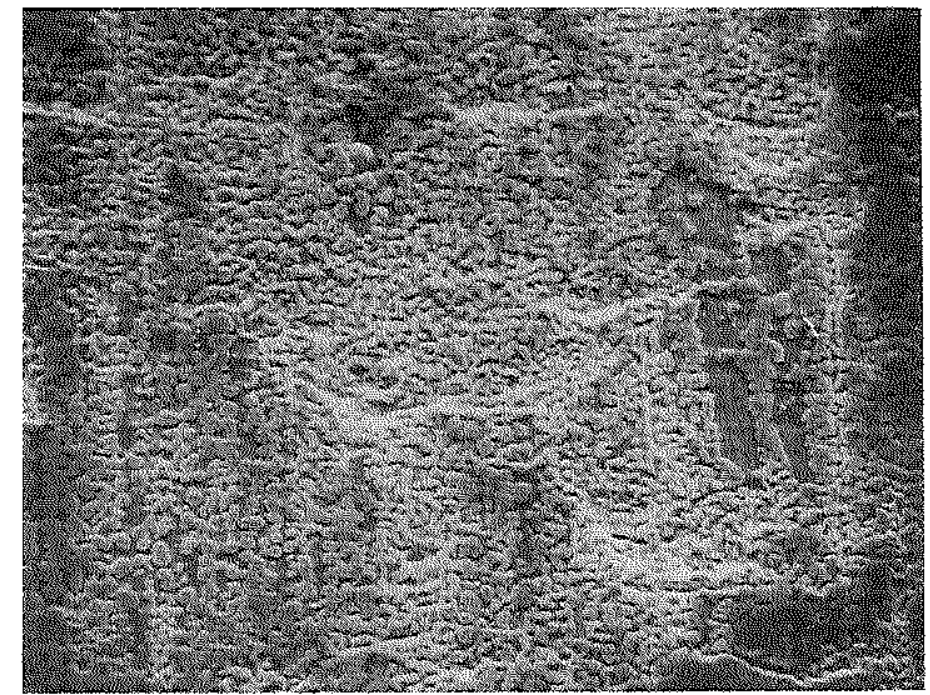

(a)

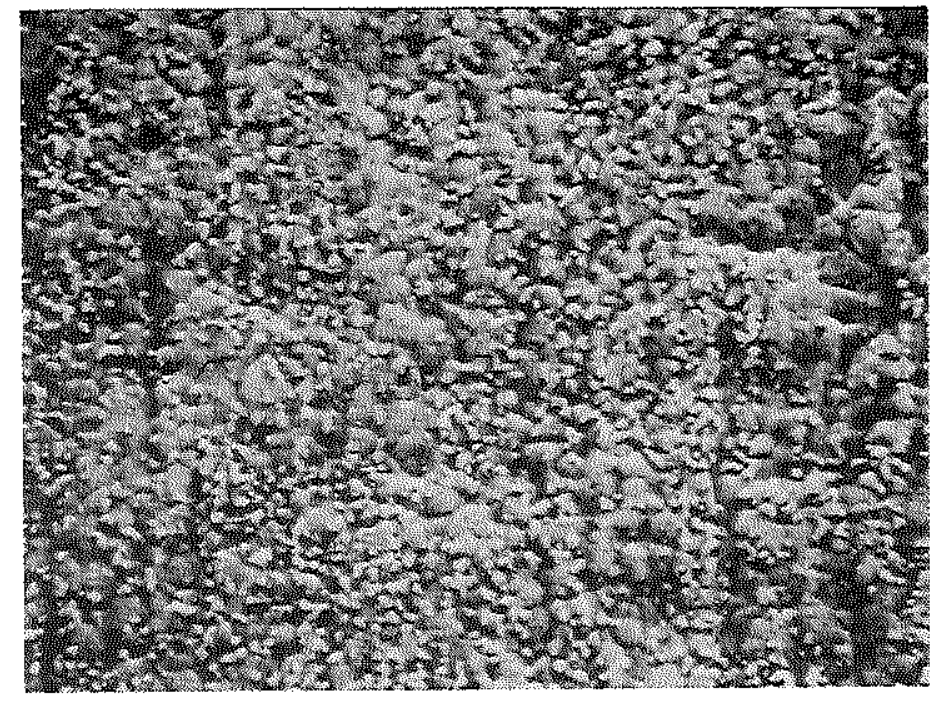

(b)

Figure 6-8. SEM Photomicrograph Of Sodium-Exposed Stainless Steels: (a) Deposit-Bearing Type 304 SS, Steam/Argon Cleaned, $500 \mathrm{x}$ (b) Corroded Type $316 \mathrm{SS}$, Water Vapor/Argon Cleaned, $500 \mathrm{x}$. 


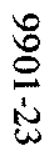

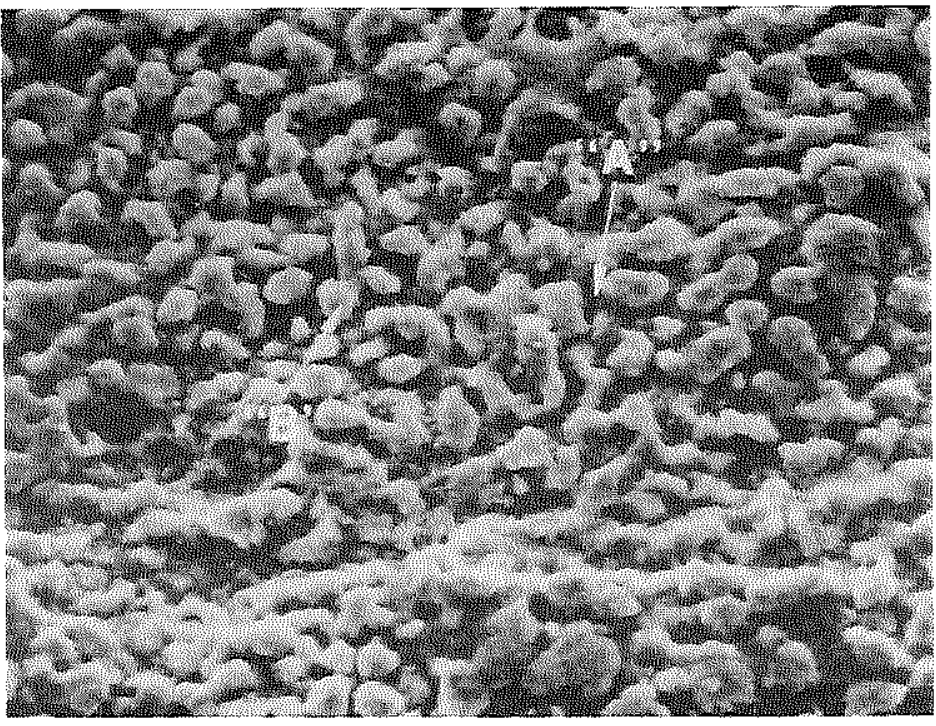

(a)

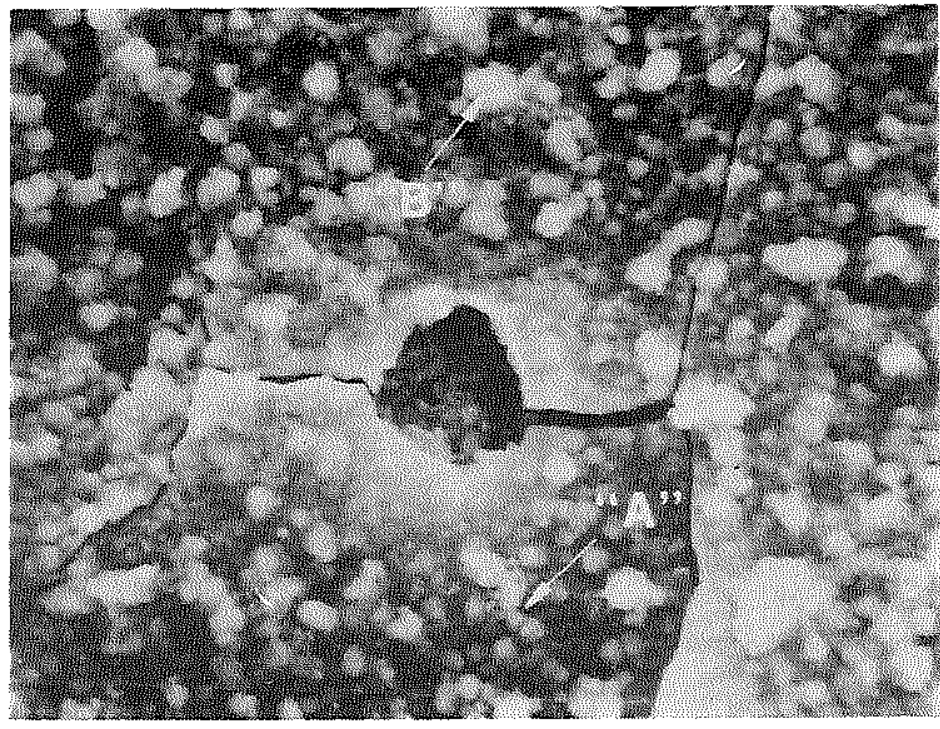

(b)

Figure 6-9. SEM Photomicrograph Of Deposit Bearing Sodium-Exposed Type 304 SS (A) Sodium-Exp. At $454^{\circ} \mathrm{C}$ For 3500 Hours Sodium Removal By Steam/Argon Process (b) Sodium-Exp. At $525^{\circ} \mathrm{C}$ For 3500 Hours. Sodium Removal By Steam/Argon Process, And Water-Exp. In High Chloride And Neutral Bath At $82^{\circ} \mathrm{C}$ For 72 Hours 

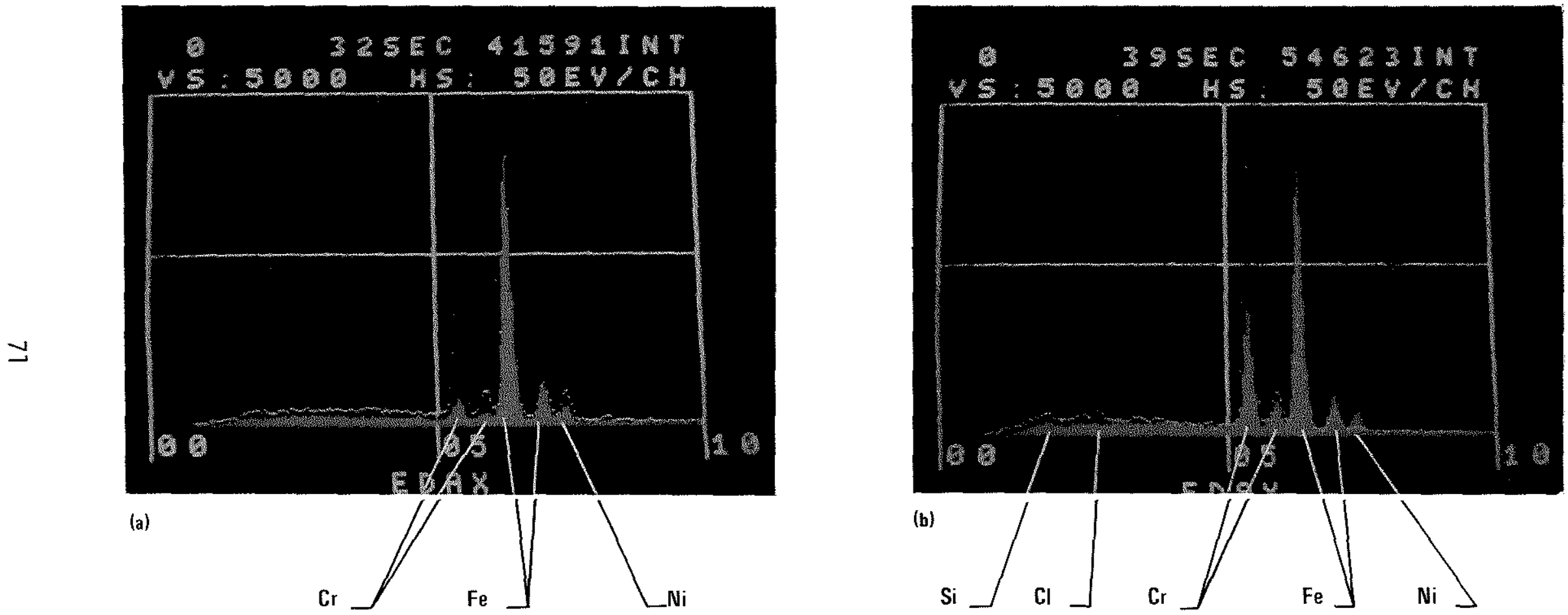

Figure 6-10. EDAX Analysis Of Deposit-Bearing, Na-Exp., And Steam/Argon Cleaned Type 304 SS (a) Pre-Water Exp., Dots - Matrix ("A" Sites In Figure 6-9 (a)). Bars - ppt. ("B" Sites In Figure 6-9 (a)). (b) Post-Water Exp. Bars - Matrix, ("A" Sites In Figure 6-9 (b)). Dots - ppt. ("B" Sites In Figure 6-9 (b)). 


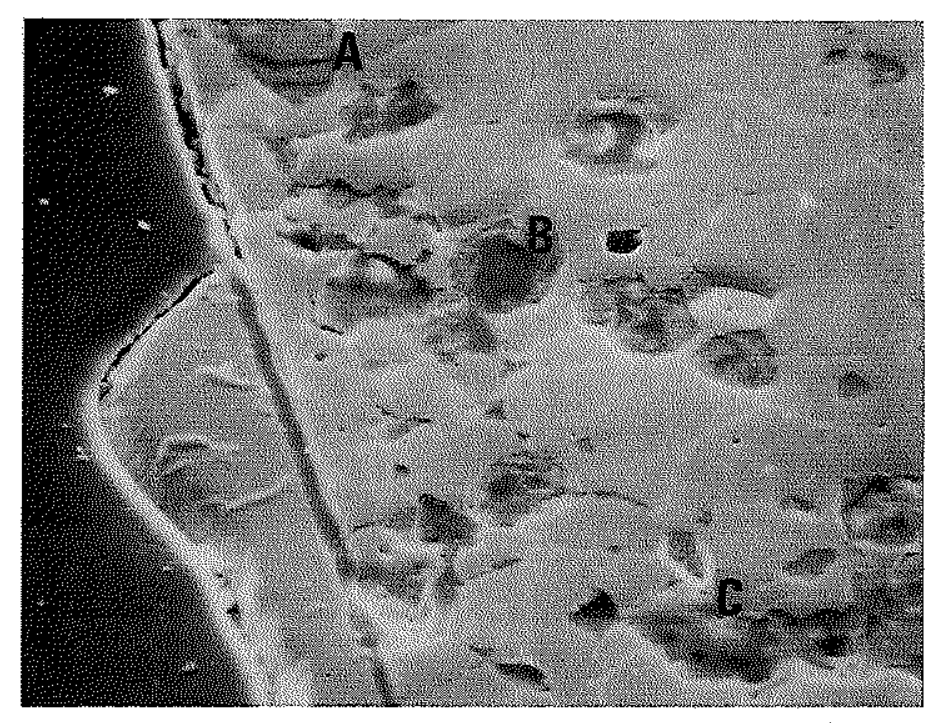

(a)

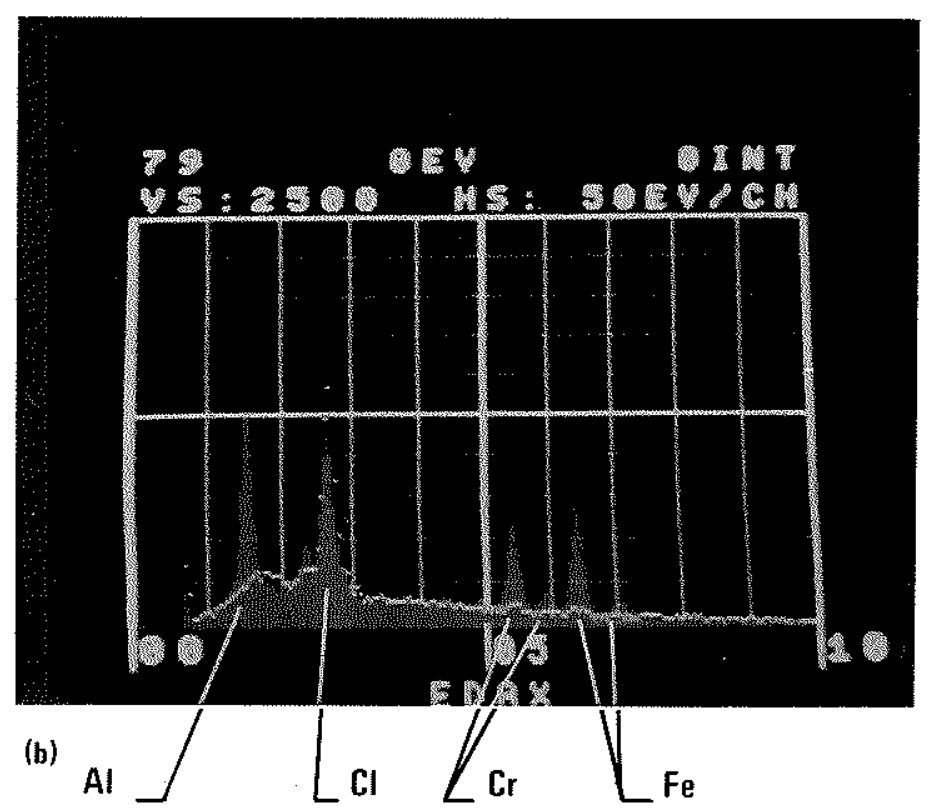

Figure 6-11. SEM And EDAX Analysis Of Deposit-Bearing Type 304 SS After Water Exposure (a) Intergranular Cracking And The Formation Of Reaction Products. 500/(b) EDAX Analysis Of The Reaction Products Dots - Particle "A" Bars - Particle "B". 
$\frac{8}{8}$
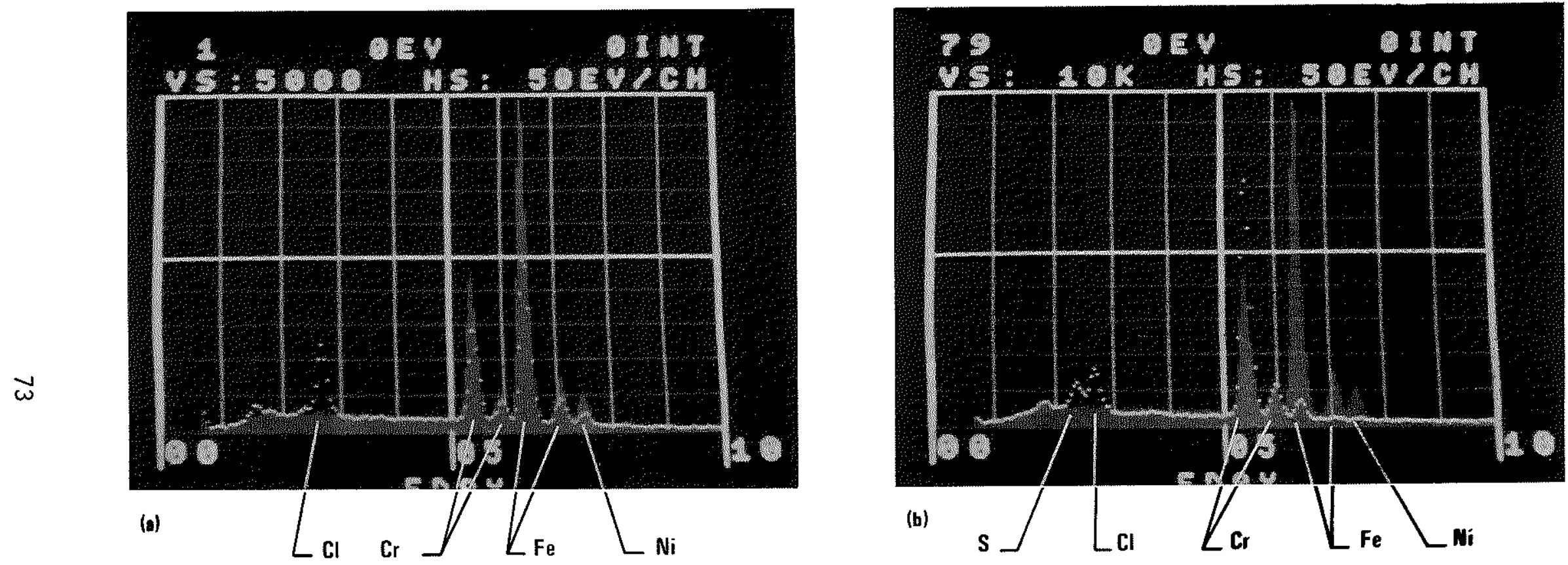

Figure 6-12. EDAX Analysis Of The Reaction Products Shown In Figure 6-11 (a) Dots: Partical "B", Bars - Type 304 SS Matrix. (b) Dots - Particle "C", Bars - Type 304 SS Matrix. 


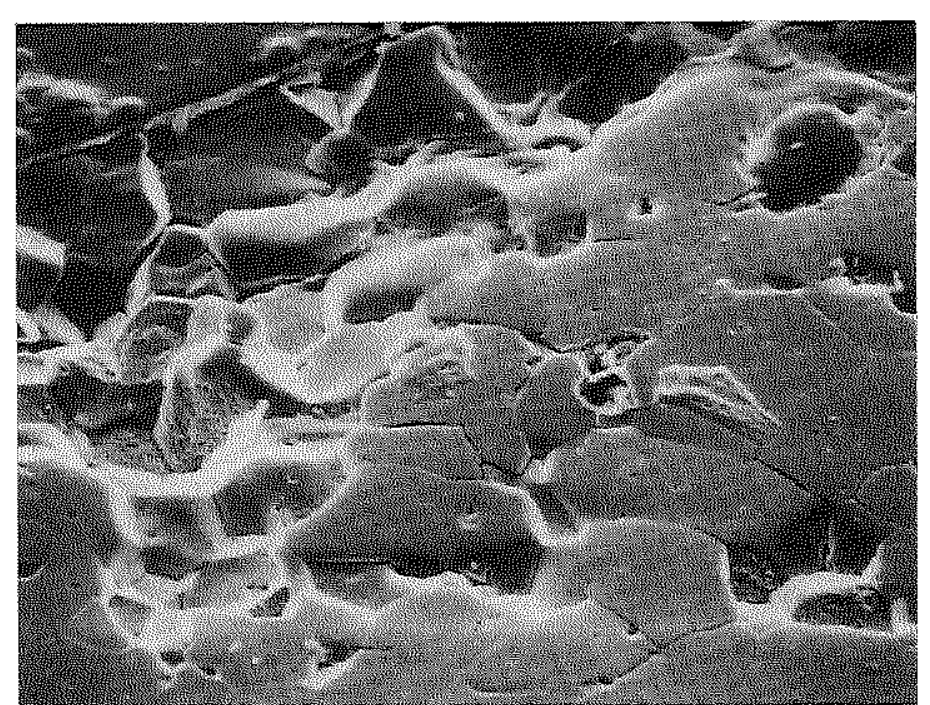

(a)

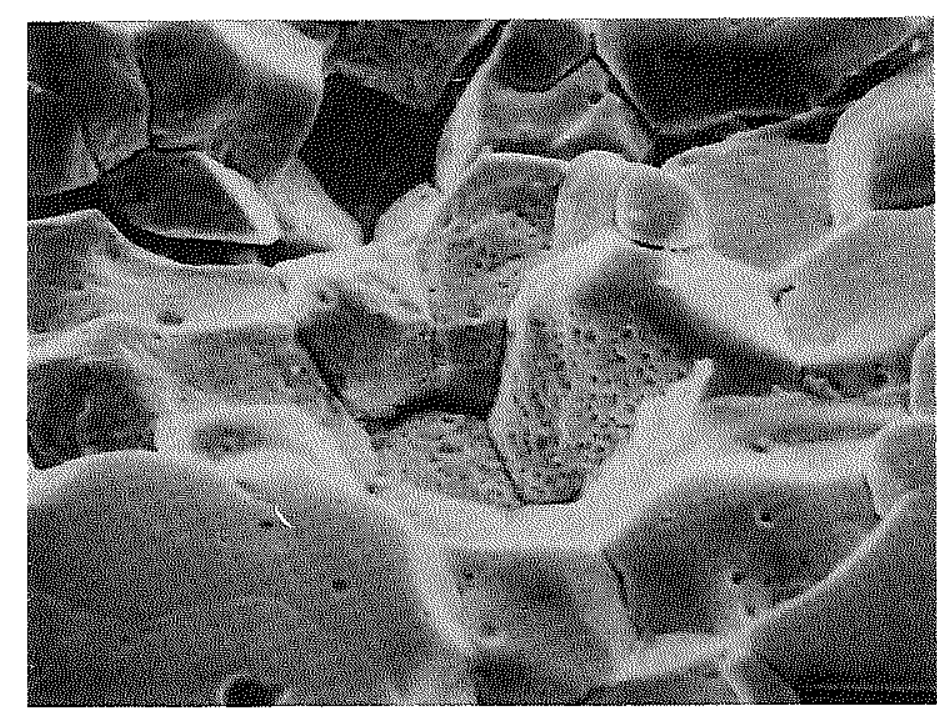

(b)

Figure 6-13. SEM Photomicrographs Of Sodium-Exposed Type 304 SS After High Chloride And Neutral Water Exposure (a) Intergranular Cracking Occurred At The Alloy/Water Interface, $500 \mathrm{x}$ (b) Close View Of The Pitting And The Intergranular Cracking, $1000 \mathrm{x}$ 


\subsection{CONCLUSION}

\subsection{Corroded Type 316 Stainless Steel}

Based on the results obtained to date, it can be concluded that sodiumcorroded Type 316 stainless steel, prototypic LMFBR cladding alloy, shows no visible deterioration or failure in any one of the four water solutions investigated in the present study. Although the exposure time of five (5) months, three months of intended exposure and two months of extended exposure, was relatively short compared to the proposed storage periods of up to twenty-four (24) months in the Hot Pilot Plant (HPP), it is anticipated that the chemistry, particularly the chloride content of the proposed water storage pool will be controlled at a significantly lower level than those investigated in the present study. Consequently, it is reasonable to believe that the fuel cladding would maintain its integrity in a water pool where chloride level may be as high as $2 \mathrm{ppm}$.

The satisfactory performance of the corroded Type 316 stainless stee 1 specimens in the high chloride water solutions are mainly due to two factors: 1) massive intragranular carbide precipitation due to severe cold work prevented the alloy from sensitizing during high temperature sodium exposure, which in turn reduces the susceptibility of this alloy to intergranular attack, and 2) the presence of a ferrite layer with high molybdenum enhanced the alloy's resistance to localized pitting corrosion.

\subsection{Deposit-Bearing Type 304 Stainless Steel}

The results on the corrosion behavior of the deposit-bearing Type 304 stainless steel were unsatisfactory. Surface rust occurred on specimens exposed in all four (4) water baths. However, failure occurred only in the two high chloride baths with six (6) failures in the high chloride neutral bath and only one failure in high chloride and high pH bath. Consequently, it appears that high pH tends to enhance the corrosion 
resistance of the test material. Since the failures involved specimens sodium removed by all three cleaning processes, it can be concluded that sodium removal procedures have little or no effect on the failures observed.

The results also indicate that no failure occurred in specimens sodiumexposed at temperatures below $482^{\circ} \mathrm{C}\left(900^{\circ} \mathrm{F}\right)$. Microstructural examination showed that these specimens were not sensitized. In contrast, all failures involved specimens with sensitized structure. This appears to suggest that sensitization was the main cause of failure. However, additional testing involving annealed, sensitized, and polished sodium-exposed specimens did not show any failure in the high chloride and neutral bath in both pressurized and nonpressurized conditions. This observation strongly indicates that the failure was not due to internal pressurization and it was caused by a combination of the presence of the sodium mass transfer deposits and the sensitization effect.

Based on the metallographic examination and electron microscopic analyses, the failure mode involved in the deposit-bearing Type 304 stainless steel specimens was apparently initiated by localized severe pitting, and accelerated by intergranular attack of the sensitized structure. The presence of sodium mass transfer deposits, particularly iron particles, apparently initiated and accelerated the pitting corrosion of the test material. 


\subsection{Recommendations}

Based on this initial study, it is reasonable to conclude that water pool storage of LMFBR spent fuel is indeed feasible, provided the purity of the water is maintained in a neutral or slightly basic state with a chloride concentration of less than two (2) $\mathrm{ppm}$.

Although the sodium removal processes have no significant effect on the subsequent water corrosion behavior, based on economical and efficiency reasons the water vapor/argon or water vapor/nitrogen process with its lower operating temperature is recommended as the reference sodium removal process for spent fuels. It is recognized that the sodium removal processes employed in the present investigation were non-prototypic, on a production line, due to the relatively long cleaning periods. Also, effectiveness and efficiency of cleaning could not be evaluated due to the simple geometry of the specimens, i.e. cylindrical. Therefore, it is recommended that additional studies be conducted to determine the effects of rapid sodium removal by various processes, and that one process be selected for evaluation of the effectiveness of sodium removal from a complex geometry prototypic to LMFBR spent fuel assembly.

Since the present investigation is a screening test, additional studies are necessary to enhance the statistical confidence of the results obtained in the current study, and to determine the limitations and purity conditions of the water to ensure an acceptable risk for storage. In addition, irradiated Type 316 stainless steel specimens should be tested in order to assess the effect of radiation on the corrosion resistance of sodium-exposed Type 316 stainless steel when exposed to prototypic water pool storage condition.

Although the results obtained from the present scoping study show unsatisfactory performance of the deposit-bearing Type 304 stainless steel, it is necessary to investigate the effect of sodium mass transfer deposits on the corrosion behavior of LMFBR fuel cladding, 20\% cold-worked Type 316 stainless steel. 


\subsection{REFERENCES}

1. J. L. English, "Considerations for Use of Water Coolant for Decay Storage of Liquid-Metal Fast Breeder Spent Fuel Elements - A Literature Survey", ORNL/TM-5762, Apri1, 1977.

2. C. A. Zimmerman and D. W. Rhodes, "Integrity of Stainless Stee 1 Cladding on EBR-II Fuel in Water", IN-1331, October, 1969.

3. B. Weiss and R. Stickler, "Phase Instabilities During High Temperature Exposure of 316 Austenitic Stainless Steel". Metallurgical Transactions, Vo1. 3, p. 851, Apri1, 1972. 
ORNL/TM-6068

Dist. Category UC-79C

INTERNAL DISTRIBUTION

1. J. T. Bel1

2. M. Bender

3. M. R. Bennett

4. R. E. Blanco

5. J. 0. Blomeke

6. R. Bl umberg

7. W. D. Bond

8. B. F. Bottenfield

9. E. C. Bradley

10. N. C. Bradley

11. R. E. Brooksbank

12. K. B. Brown

13-22. W. D. Burch

23. D. D. Cannon

24. J. M. Chandler

25. W. E. Clark

26. L. T. Corb in

27. D. A. Costanzo

28. R. M. Counce

29. D. J. Crouse

30. B. F. Crump

31. F. L. Culler

32. J. P. Drago

33. B. C. Duggins

34. D. E. Dunning

35. J. H. Evans

36. M. J. Feldman

37. D. E. Ferguson

38. L. M. Ferris

39. S. D. Floyd

40. J. Garin

41. J. H. Goode

42. N. R. Grant

43. W. S. Groenier

44. W. R. Hamel

45. D. C. Hampson

46. B. A. Hannaford

47. W. 0. Harms

48. J. N. Herndon

49. R. M. Hill

50. W. D. Holland

51. D. E. Horner

52. A. R. Irvine

53. J. D. Jenkins

54. R. T. Jubin
55. P. R. Kasten

56. A. D. Kelmers

57. L. J. King

58. J. Q. Kirkman

59. J. A. Klein

60. C. E. Lamb

61. B. E. Lewis

62. M. H. Lloyd

63. A. L. Lotts

64 J. C. Mailen

65. A. P. Mal inauskas

66. D. L. Manning

67. L. Maya

68. J. D. McGaugh

69. L. E. McNeese

70. S. A. Meacham

71. R. P. Milford

72. A. D. Mitchell

73. J. G. Morgan

74. J. M. Morrison

75. E. L. Nicholson

76. E. D. North

77. J. H. Pashley

78. F. L. Peishe]

79. H. Postma

80. R. H. Powell

81. R. H. Rainey

82. G. W. Renfro

83. J. E. Rushton

84. W. F. Schaffer, Jr.

85. C. D. Scott

86. T. Shapiro

87. B. B. Spencer

88. R. G. Stacy

89. M. J. Stephenson

90. J. G. Stradley

91. D. W. Swindle

92. 0. K. Tallent

93. D. B. Trauger

94. W. E. Unger

95. J. E. Van Cleve

96. V. C. A. Vaughen

97. B. L. Vondra

98. C. D. Watson

99. B. S. Weil 
100. T. D. Welch

101. M. E. What ley

102. J. R. White

103. R. G. Wymer

104. 0. 0. Yarbro

105. S. Beard (consultant)

106. Manson Benedict (consultant)

107. L. Burris, Jr. (consultant)

108. A. B. Carson (consultant)

109. G. R. Choppin (consultant)

110. E. L. Gaden, Jr. (consul tant)

111. C. H. Ice (consultant)

112. W. H. Lewis (consultant)

113. A. Schneider (consultant)

114. L. E. Swabb, Jr. (consultant)

115. M. J. Szul inski (consultant)

116. J. S. Theilacker (consultant)

117. K. D. Timmerhaus (consultant)

118. A. K. Williams (consultant)

119-120. Central Research Library

121. ORNL-Y-12 Technical Library, Document Reference Section

122-123. Laboratory Records

124. Laboratory Records, ORNL RC

125. ORNL Patent Office

126. Nuclear Safety Information Center 
127. Director, Reactor Division, DOE-ORO

128-129. Director, Division of Nuclear Fuel Cycle and Production, DOE, Washington, D.C. 20545

130-131. Director, Division of Reactor Research and Development, DOE, Washington, D.C. 20545

132. M. L. Bleiberg, Westinghouse Electric Corporation, Advanced Reactors Division, Waltz Mill Site, P. 0. Box 158, Madison, PA 15663

133. R. B. Chitwood, Chief, Industrial Programs Branch, Division of Waste Management, Production, and Reprocessing, DOE, Washington, D.C. 20545

134. Duane E. Clayton, Battelle Pacific Northwest Laboratory, P. 0. Box 999, Richland, WA 99352

135. Martin Friedland, Gulf + Western Advanced Development and Engineering Center, 101 Chester Road, Swarthmore, PA 19081

136. Jerry M. Friedman, Sandia Laboratories, P. 0. Box 5800, Albuquerque, NM 87115

137. Frank J. Jones, Bechtel Corporation, P. 0. Box 3965, San Francisco, CA 94119

138. B. F. Judson, Vice-President \& Mgr., GEUMCO-Engineering, 175 Curtner Avenue - Mail Code 858, San Jose, Cal ifornia 95125

139. R. S. Karinen, Programmed and Remote Systems Corporation, 3460 Lexington Avenue, St. Paul, MN 55112

140. Robert H. Karlsson, Rockwell International, Atomics International Division, Rocky Flats Plant, P. 0. Box 464, Golden, C0 80401

141. W. H. McVey, Chief, Technology Branch, Division of Waste Management, Production, and Reprocessing, DOE, Washington, D.C. 20545

142. R. E. Mullen, Aerojet Manufacturing Company, 601 South Placentia Avenue, P. 0. Box 4210, Fullerton, CA 92634

143. W. S. Scheib, Jr., Chief Projects Branch, Division of Waste Management, Production, and Reprocessing, DOE, Washington, D.C. 20545

144. D. R. Spurgeon, Acting Assistant Director for Reprocessing, Division of Waste Management, Production, and Reprocessing, DOE, Washington, D.C. 20545

145. D. E. Wood, Kaman Sciences Corporation, 1500 Garden of the Gods Road, P. 0. Box 7463, Colorado Springs, C0 80933

146. Research and Technical Support Division, DOE-ORO

147-398. Given distribution as shown in TID-4500 under UC-79c, Fuel Recycle Category (Applied) 


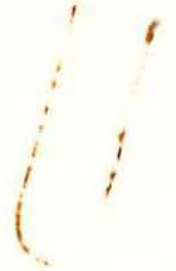


$C R L$

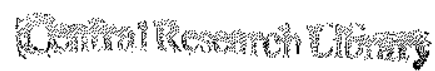

JAN 1970 